\title{
Quantifying the uncertainty in simulating global tropospheric composition due to the variability in global emission estimates of Biogenic Volatile Organic Compounds
}

\author{
J. E. Williams ${ }^{1}$, P. F. J. van Velthoven ${ }^{1}$, and C. A. M. Brenninkmeijer ${ }^{2}$ \\ ${ }^{1}$ Royal Netherlands Meteorological Institute, De Bilt, The Netherlands \\ ${ }^{2}$ Max Planck Institute for Chemistry, Atmospheric Chemistry, Mainz, Germany \\ Correspondence to: J. E. Williams (williams@ knmi.nl)
}

Received: 24 July 2012 - Published in Atmos. Chem. Phys. Discuss.: 5 November 2012

Revised: 17 January 2013 - Accepted: 13 February 2013 - Published: 11 March 2013

\begin{abstract}
The emission of organic compounds from biogenic processes acts as an important source of trace gases in remote regions away from urban conurbations, and is likely to become more important in future decades due to the further mitigation of anthropogenic emissions that affect air quality and climate forcing. In this study we examine the contribution of biogenic volatile organic compounds (BVOCs) towards global tropospheric composition using the global 3-D chemistry transport model TM5 and the recently developed modified CB05 chemical mechanism. By comparing regional BVOC emission estimates we show that biogenic processes act as dominant sources for many regions and exhibit a large variability in the annually and seasonally integrated emission fluxes. By performing sensitivity studies we find that the contribution of BVOC species containing between 1 to 3 carbon atoms has an impact on the resident mixing ratios of tropospheric $\mathrm{O}_{3}$ and $\mathrm{CO}$, accounting for $\sim 2.5 \%$ and $\sim 10.8 \%$ of the simulated global distribution, respectively. This is approximately a third of the cumulative effect introduced by isoprene and the monoterpenes. By examining an ensemble of 3-D global chemistry transport simulations which adopt different global BVOC emission inventories we determine the associated uncertainty introduced towards simulating the composition of the troposphere for the year 2000. By comparing the model ensemble values against a composite of atmospheric measurements we show that the effects on tropospheric $\mathrm{O}_{3}$ are limited to the lower troposphere (with an uncertainty between $-2 \%$ to $10 \%$ ), whereas that for tropospheric $\mathrm{CO}$ extends up to the upper troposphere (with an uncertainty of between 10 to $45 \%$ ). Comparing the mixing
\end{abstract}

ratios for low molecular weight alkenes in TM5 against surface measurements taken in Europe implies that the cumulative emission estimates are too low, regardless of the chosen BVOC inventory. This variability in the global distribution of $\mathrm{CO}$ due to BVOC emissions introduces an associated uncertainty in the tropospheric CO burden of $11.4 \%$, which impacts strongly on the oxidative capacity of the troposphere, introducing an uncertainty in the atmospheric lifetime of the greenhouse gas $\mathrm{CH}_{4}$ of $\sim 3.3 \%$. This study thus identifies the necessity of placing further constraints on non$\mathrm{CH}_{4}$ global biogenic emission estimates in large-scale global atmospheric chemistry models.

\section{Introduction}

One of the principle emission sources of trace gas species at global scale is the natural environment, where both aerobic and anaerobic oxidation processes that occur in vegetation and soils release a range of different Biogenic Volatile Organic Compounds (BVOCs) into the lower troposphere (LT, Fowler et al., 2009). The most abundant of these BVOC species are isoprene $\left(\mathrm{C}_{5} \mathrm{H}_{8}\right)$ and monoterpenes $\left(\mathrm{C}_{10} \mathrm{H}_{16}\right)$, where current global estimates range from between 412 $601 \mathrm{Tg} \mathrm{C} \mathrm{yr}^{-1}$ and 32-121 $\mathrm{Tg} \mathrm{C} \mathrm{yr}^{-1}$, respectively (Arneth et al., 2008), with more recent estimates being $472{\mathrm{Tg} \mathrm{C} \mathrm{yr}^{-1}}^{-1}$ and $145 \mathrm{Tg} \mathrm{Cyr}^{-1}$, respectively (Guenther et al., 2012). In addition, biogenic processes which occur in the soil and ocean also emit significant amounts of carbon monoxide (CO), formaldehyde ( $\mathrm{HCHO})$, methanol $\left(\mathrm{CH}_{3} \mathrm{OH}\right)$, ethene 
$\left(\mathrm{C}_{2} \mathrm{H}_{4}\right)$, ethane $\left(\mathrm{C}_{2} \mathrm{H}_{6}\right)$, propane $\left(\mathrm{C}_{3} \mathrm{H}_{8}\right)$, propene $\left(\mathrm{C}_{3} \mathrm{H}_{6}\right)$ and acetone $\left(\mathrm{CH}_{3} \mathrm{COCH}_{3}\right)$. Typically emission estimates from the oceans range from between $10-100 \mathrm{Tg} \mathrm{yr}^{-1}$ for CO (Khalil, 1999) to rather low estimates of around $<1.0$

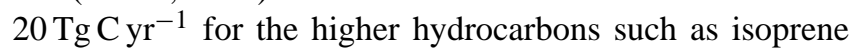
and the monoterpenes (e.g. Gantt et al., 2009; Colomb et al., 2009; Luo and Yu, 2010). For soil emissions, the estimates of the C1-C3 BVOC emissions are larger between $0-110 \mathrm{Tg} \mathrm{Cyr}^{-1}$ (see details provided in this study). With the exception of $\mathrm{CO}$ and the alkenes, these organic compounds typically have atmospheric lifetimes of between 212 days (e.g. Jenkins and Clemitshaw, 2000; Tie et al., 2003; Fischer et al., 2012). Once emitted their removal occurs by photochemical oxidation in the troposphere (Atkinson, 2000) or loss by deposition processes, depending on the chemical nature of each compound. The highest emission fluxes of BVOCs occur over tropical forested regions that are usually sparsely populated and thus are not affected directly by anthropogenic emission sources. Most emission inventories of BVOCs are calculated using approaches based on the empirical algorithm of Guenther et al. (1995), where different input parameters for land cover type and the physiological activity of vegetation types are adopted (Arneth et al., 2008). It is currently difficult to constrain estimates of biogenic emissions using observations due to the high temporal and geographic variability in their fluxes. For example, isoprene does not have a characteristic absorption region in the electromagnetic spectrum which can be exploited by satellite instruments. Therefore, their emission fluxes are usually constrained by monitoring their oxidation products such as HCHO (e.g. Palmer et al., 2003). Furthermore retrievals of other BVOC species such as $\mathrm{CH}_{3} \mathrm{OH}$ and $\mathrm{HCOOH}$ have recently been performed from earth-orbiting satellites (e.g. Razavi et al., 2011; Stavrakou et al., 2012) and used to both validate the performance of biogenic process models and derive improved global emission estimates which can be larger than the bottom-up estimates in global emission inventories (Stavrakou et al., 2011). For $\mathrm{HCOOH}$, although biogenic sources can be identified, there are strong emissions from biomass burning (BB) events which complicate attribution of seasonal emission fluxes (Razavi et al., 2011).

Previous modelling studies have shown that the distribution of oxidants such as tropospheric ozone $\left(\mathrm{O}_{3}\right)$ are sensitive to the emission of BVOCs at both global (e.g. von Kuhlmann et al., 2004; Pfister et al., 2008; Williams et al., 2009) and regional (e.g. Simpson, 1995; Tao et al., 2003; Roberts et al., 2006; Li et al., 2007; Curci et al., 2009) scales. Sensitivity studies have shown that there is generally an enhancement in the oxidative capacity of the troposphere as a result of an increase in the resident molar mixing ratios of $\mathrm{O}_{3}$, and thus $\mathrm{OH}$, due to the presence of BVOCs. This subsequently decreases the atmospheric lifetimes of reactive trace gas species. Therefore the accuracy of any atmospheric model towards simulating the seasonal cycles of dominant trace gas species is affected by the accuracy of the temporal distribution and inte- grated fluxes of biogenic emission estimates that are included in large-scale models, especially during boreal summertime where biogenic activity in the Northern Hemisphere (NH) is high. This seasonality is likely to become more important in a future climate, where simulations using a dynamic global vegetation model suggest biogenic emission fluxes will increase due to increases in surface temperatures (Lathiére et al., 2005), where isoprene emission fluxes have been found to scale almost linearly in response to temperature (Im et al., 2011). If such a scenario becomes reality, and assuming the mitigation and abatement of future anthropogenic emissions occurs according to recent predictions (Lamarque et al., 2010), then accounting for biogenic emissions and the accuracy of the estimates will have an enhanced impact towards assessing trends in atmospheric composition and future airquality (Hauglustaine et al., 2005; Wiedinmyer et al., 2006).

Some atmospheric models now simulate the emission of isoprene online i.e. they use the temperature values in the meteorological data fields used to drive the model, along with the extent of illumination, to calculate the resident emission fluxes (e.g. Wang and Shallcross, 2000; Im et al., 2011). Given that climatic extremes are likely to increase in frequency in the coming decades this online approach has the potential to capture a more realistic variability in isoprene emissions, assuming the algorithms are able to perform well over a typical range in temperatures and soil moisture regimes. Sensitivity studies have shown that the resulting biogenic emission fluxes calculated online are fairly sensitive to the update frequency at which the meteorological input fields are applied (Ashworth et al., 2010) and to assumptions regarding the other variables used to calculate the emission flux online (Guenther et al., 2006). Moreover, algorithms designed to relate the release of isoprene towards physical environmental variables, such as temperature, still do not account for the feedback of the efficiency of the emission of the terpenes towards changing atmospheric levels of carbon dioxide, which is thought to be important (Niinemets et al., 2010). However, one drawback of adopting an online method for calculating BVOC emission fluxes is that the implementation often does not cover all of the BVOC species released for which regional emission fluxes from biogenic sources dominate e.g. $\mathrm{CH}_{3} \mathrm{OH}$ and $\mathrm{CH}_{3} \mathrm{COCH}_{3}$. Therefore some offline BVOC estimates are commonly used in tandem with online isoprene estimates to account for the significant contribution of BVOC species towards the composition of the tropical troposphere and unpopulated regions. More recently, a version of the Model of Emissions of Gases and Aerosols from Nature (MEGAN) has become available that calculates emissions of over 100 BVOC species (Guether et al., 2012) which has the potential to harmonize BVOC emissions with respect to meteorological variability.

Due to computational efficiency, many global ChemistryClimate Models (CCMs), Chemistry-Transport Models (CTMs) and regional air-quality models still use offline BVOC emission inventories which are readily available to 
the modeling community (e.g. http://accent.aero.jussieu.fr). Such inventories are calculated using archived data from either climate models or meteorological models, such as those available from e.g. the European Centre for Medium range Weather Forecasting (ECMWF) or the National Centre for Environmental Prediction (NCEP). These emission fluxes are therefore independent from the meteorological fields used to drive the transport in any atmospheric model, although typical seasonal variations in temperature and precipitation for different world regions are used to calculate the offline global BVOC inventories. The various BVOC climatologies are calculated using meteorological data for different time periods. In general, they are typically averages of emission fluxes calculated for time-slices ranging from a few years to a few decades (Arneth et al., 2008). This avoids introducing biases into the BVOC emission estimates due to extreme meteorological events which may occur for specific global regions during any specific year e.g. summer 2003 when an extreme European heat wave occurred. Moreover, each biogenic climatology is calculated using different input fields (e.g. land-use maps, the distribution of the Leaf Area Index (LAI)) which can result in large differences in BVOC estimates for tropical regions such as Africa (e.g. Williams et al., 2009). Therefore the choice of biogenic climatology introduces a degree of uncertainty when simulating trends in e.g. tropospheric $\mathrm{O}_{3}$, the atmospheric lifetimes of long-lived gases such as methane $\left(\mathrm{CH}_{4}\right)$ or the variability in composition of the tropical troposphere. Although previous studies using global atmospheric models have focused on the uncertainties in tropospheric composition introduced by adopting different projections for anthropogenic emissions (e.g. Horowitz, 2006; Williams and van Velthoven, 2011), to the authors knowledge the uncertainty introduced by the sometimes large variability in BVOC emission estimates at global scale has not yet been fully investigated in detail.

In this paper we address this issue by quantifying the sensitivity of tropospheric composition and oxidative capacity towards different BVOC climatologies in the 3-D global CTM Tracer Model 5 (TM5). By using a range of BVOC emission estimates we investigate the associated uncertainty introduced with respect to dominant trace gas species such as $\mathrm{O}_{3}$ and $\mathrm{CO}$, as well as the oxidative capacity and, consequently, the atmospheric lifetimes. In Sect. 2 we provide details of the simulations including a description of the modified CB05 chemical mechanism applied in TM5. In Sect. 3 we compare the seasonal differences between four alternative BVOC climatologies for five different global regions and for the global scale to highlight the important contribution of BVOC emissions of C1-C3 compounds to cumulative emission estimates. In Sect. 4 we investigate the impact that nonisoprene BVOC species have on tropospheric composition during the year 2000 and quantify the importance of these C1-C3 BVOC species compared to the influence of isoprene and the monoterpenes. In Sect. 5 we quantify the uncertainty introduced towards the composition of the troposphere as a result of adopting the various biogenic emission climatologies. For this purpose we examine the changes introduced into the seasonal ensemble mean and assess the importance of such uncertainty by making comparisons against various measurements. In Sect. 6 we quantify the resulting uncertainty introduced for the simulated global distribution of tropospheric $\mathrm{O}_{3}$ and $\mathrm{CO}$ due to variability in BVOC emission estimates and in Sect. 7 we present the associated uncertainty introduced towards global burdens and lifetimes. Finally in Sect. 8 we present our conclusions.

\section{Model description}

The 3-D global chemistry-transport model (CTM) used in this study is TM5 (Huijnen et al., 2010). We perform simulations using 34 vertical layers at a horizontal resolution of $3^{\circ} \times 2^{\circ}$ and drive the CTM with ECMWF meteorological fields taken from the ERA-interim re-analysis (Dee et al., 2011), with an update frequency of $3 \mathrm{~h}$. The version of TM5 used here utilizes a recently implemented online photolysis scheme, which has been shown to improve the performance of TM5 and increase the oxidative capacity in the model (Williams et al., 2012a). Given that TM5 is a tropospheric model, the overhead stratospheric ozone profile shape is constrained by relaxation towards the sonde-based climatology of Fortuin and Kelder (1998), while the total stratospheric $\mathrm{O}_{3}$ column is scaled to the observed monthly mean total ozone columns assimilated from a multi-sensor reanalysis dataset (van der A et al., 2010). For a more comprehensive description of the parameterizations and structure of TM5 the reader is referred to both Huijnen et al. (2010) and Williams et al. (2012a). The chosen simulation year for this study is the year 2000, which is considered to exhibit rather standard meteorological variability without any pronounced extremes which would have the potential to introduce biases when comparing against measurements. A oneyear spin-up is performed for all simulations using the relevant emissions inventories and meteorology for 1999.

\subsection{The modified CB05 mechanism}

The chemical mechanism which is employed in this study is the recently developed modified CB05 scheme, which is a reduced version of the $\mathrm{CB} 05$ chemical scheme described in Yarwood et al. (2005), where $\mathrm{CH}_{3} \mathrm{COCH}_{3}$ chemistry has also been added and selected reactions and/or product distributions taken from Zaveri and Peters (1999). This replaces the modified CBM4 chemical mechanism (Houweling et al., 1998) which has been used for multiple chemical studies in TM5 to date (e.g. Ordñez et al., 2010). Global emission estimates for many of the lower molecular weight $\mathrm{C} 1-\mathrm{C} 3$ organic species are now readily available thus providing motivation for the explicit inclusion of such trace species in TM5. This reduces the number of VOC species which are 
lumped into more generic CBM tracer species included to represent chemical reactivity of e.g alkylinic and olefinic carbon bonds. The chemical mass balance of the modified CB05 mechanism is closer to unity when compared to that of the modified CBM4 mechanism, where updated stoichiometry associated with the oxidation of e.g. organic nitrates (ORGNTR) and higher peroxides (ROOH) has been shown to increase the production efficiency of tropospheric $\mathrm{O}_{3}$ in the CB05 mechanism compared to previous versions of the CBM mechanism (Saylor and Stein, 2012).

In terms of isoprene oxidation it has been shown that the implicit loss of intermediates in the modified CBM4 mechanism can introduce significant differences of up to $~ 30-60 \%$ (equivalent to $10 \mathrm{ppb}$ ) in tropospheric $\mathrm{O}_{3}$ when compared against other alternative mechanisms employed in CTMs (von Kuhlmann et al., 2004). The isoprene oxidation mechanism in the modified CB05 scheme is more extensive than that in the modified CBM4 mechanism, where it includes an intermediate tracer species which lumps both methacrolein and methyl vinyl ketone together (designated as ISPD) in order to provide a better representation of the principle oxidation products of isoprene and the monoterpenes (Atkinson, 2000). Modifications have been made to both the oxidation rate of $\mathrm{ROOH}$ and the production efficiency of $\mathrm{HO}_{2}$ from the $\mathrm{OH}$ initiated oxidation of isoprene according to the recommendations given in Archibald et al. (2010). It should be noted that the more recent findings regarding the regeneration of $\mathrm{OH}$ and $\mathrm{HO}_{2}$ during isoprene oxidation (e.g. Stavrakou et al., 2010) are not yet accounted for in this study.

For reasons of numerical stability associated with the Eulerian Backward Iterative (EBI) solver (Hertel et al., 1993) we omit the formation of higher PAN compounds, although these tend to be more reactive thus making smaller contributions to the long range transport of nitrogen oxides $\left(\mathrm{NO}_{\mathrm{x}}\right)$ out of the main source regions than PAN itself (von Kuhlmann et al., 2004). For higher aldehydes (denoted ALDX in CB05) we assume a short atmospheric lifetime and therefore introduce the main oxidation products instead. Due to their relatively low global emission fluxes, we also choose to exclude the higher molecular weight organic species from the modified CB05 scheme (e.g. toluene, xylene and creosol) similar to the approach adopted by Houweling et al. (1998) for the CBM4 mechanism. We also omit IOLE from the reduced scheme which represents internal olefinic bonds.

A full description of the modified CB05 mechanism as implemented in this study is given in the Appendix in Table A1. All reaction rate data has been taken from the latest recommendations (Atkinson et al., 2006; Sander et al., 2011). Some selected reactions have been taken from other sources (e.g. the oxidation of $\mathrm{C}_{3} \mathrm{H}_{6}$ by $\mathrm{O}_{3}$ ). Details related to the additional photolysis reactions which have been added to the modified CB05 scheme are given in the Appendix in Table A2. In addition to loss by dry deposition, many of the explicit organic species introduced exhibit high to moderate solubility meaning that additional wet scavenging terms have been introduced. Dry deposition velocities are calculated using the methodology of Ganzeveld and Lelieveld (1995), although many of the additional species which have been added have not been explicitly treated there, so analogue values are applied. The dry deposition velocities for isoprene, the monoterpenes, alkanes or alkenes are assumed to be negligible. The chemical data used for the calculation of the heterogeneous scavenging rates which determines the extent of wet deposition are given in Table A3.

\subsection{Definition of the emission scenarios and sensitivity studies}

For the anthropogenic emissions of $\mathrm{CO}, \mathrm{NO}_{\mathrm{x}}, \mathrm{SO}_{2}$ and the Non-Methane Hydrocarbons (NMHC) component we adopt the RETRO inventory for the year 2000 (Schultz et al. (2007); http://retro.enes.org/) supplemented with estimates from the REAS inventory for the Asian region (Ohara et al., 2007) between the geographical limits of $60-150^{\circ} \mathrm{E}$, $10^{\circ} \mathrm{S}-50^{\circ} \mathrm{N}$. Although the modified CB05 mechanism does not include the higher aromatics (see Sect. 2.1) we also emit the main oxidation products for such species when there are emission estimates available such as for Xylene, with the aim of improving the global distribution of $\mathrm{CO}$, which has been shown to be low in TM5 for certain seasons and locations (Huijnen et al., 2010). For methane $\left(\mathrm{CH}_{4}\right)$ we use the yearly resolved EDGAR 4.2 emission inventory for anthropogenic sources (http://edgar.jrc.ec.europa.eu/), whereas for the natural emissions we use the monthly segregated LPJ-WhyMe emission inventory for the corresponding years (Spahni et al., 2011). Other natural $\mathrm{CH}_{4}$ sources include emissions from termites (Sanderson, 1996), ruminants (Olson, 1997) and the ocean (Lambert and Schmidt, 1993), which have been scaled to provide annual emission fluxes of 20,5 and $15 \mathrm{TgCH}_{4}$, respectively, following Houweling et al. (2006). We nudge the $\mathrm{CH}_{4}$ concentrations throughout the LT towards a 2-D latitudinally and monthly varying climatology based on surface observations. The $\mathrm{CH}_{4}$ mixing ratios in TM5 are then constrained by applying a 3-day relaxation time using the ratio between the simulated distribution around the dateline $\left(\sim 180^{\circ} \mathrm{E}\right)$, where the surface observations used to produce the climatology are taken between $160^{\circ} \mathrm{E}-20^{\circ} \mathrm{W}$. When introducing the emission estimates for $\mathrm{CH}_{4}$ independent tests were performed using a range of relaxation times and it was found that the 3-day relaxation time prevented both homogenization of regional differences in the distribution of $\mathrm{CH}_{4}$ mixing ratios and also limited unrealistic increases in the global distribution of $\mathrm{CH}_{4}$. For the vertical distribution it is assumed that the gradient in the boundary layer and lower free troposphere is shallow allowing the constraint to be imposed in the first few kilometers of the troposphere. Adopting such offline $\mathrm{CH}_{4}$ emission fields has been shown to improve both the regional and seasonal distribution at the surface compared to using a fixed latitudinal gradient (van Weele et al., 2013). For the emission of trace gases from 
Table 1. An overview of the biogenic inventories used in the different CTM simulations for investigating the effects of BVOCs.

\begin{tabular}{llll}
\hline Model simulation & Emission inventory & Years & Biogenic inventory \\
\hline ORCH & RETRO & $1983-1995$ & Lathiere et al. (2006) \\
MEGAN & MACCity & 2000 & Guenther et al. (2006) \\
POET & POET & $1990-2000$ & Granier et al. (2004) \\
EMAC & QUANTIFY & $2000-2003$ & Hoor et al. (2009) \\
NOBVOC & MACCity & 2000 & Guenther et al. (2006) \\
NOISOPTERP & MACCity & 2000 & Guenther et al. (2006) \\
\hline
\end{tabular}

biomass burning (BB) and wildfires we adopt the emission estimates provided in the monthly GFEDv3 inventories for all simulations (van der Werf et al., 2010). The segregation of the NMHC species into individual organic species is already provided by the data providers, where we adopt these segregated emission fluxes in TM5. Lightning $\mathrm{NO}_{\mathrm{x}}$ emissions are calculated using the parameterization of Meijer et al. (2001), where the total annual $\mathrm{NO}_{\mathrm{x}}$ emission introduced is constrained at $\sim 5.9 \mathrm{Tg} \mathrm{N} \mathrm{yr}^{-1}$.

For the investigation of the sensitivity of tropospheric composition to BVOC emission estimates we define a model ensemble containing four independent members. Each member adopts an independent global BVOC climatology, with all other variables being constant. These biogenic climatologies have all been used previously to account for biogenic emissions in both CTMs and CCMs participating in various multi-model intercomparison studies (e.g. Barret et al., 2010; Hoor et al., 2009; Ordñez et al., 2010). It includes the following 4 climatologies: (i) that provided by the Present and future surface Emissions of atmospheric compounds (POET) project (Granier et al., 2005), (ii) that calculated with the ORCHIDEE vegetation model and made available as part of the RETRO inventory (Lathiere et al., 2006), (iii) the climatology calculated by the EMAC model provided as part of the QUANTIFY inventory (Hoor et al., 2009) and (iv) the inventory provided in the MACCity emission estimates (Lamarque et al., 2010) calculated using version 2.0 of the MEGAN model (Guenther et al., 2006). These ensemble members will be called: POET, ORCH, EMAC and MEGAN, respectively.

With the exception of the MACCity inventory (which adopts meteorology for 2000 for BVOC emissions), the inventories provide climatological values which are averages for a number of consecutive years in order to avoid introducing biases due to extreme meteorological situations. It is estimated that isoprene emissions typically exhibit an inter-annual variability of between $\sim 5-10 \%$ over consecutive years (Arneth et al., 2011). The specific years used for the calculation of the different BVOC climatologies are also provided in Table 1 . For the soil $\mathrm{NO}_{\mathrm{x}}$ component the emission estimate provided in the MACCity inventory is adopted throughout all ensemble simulations, which intro-

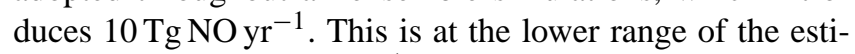

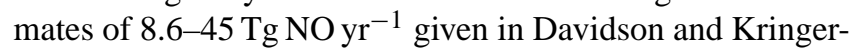

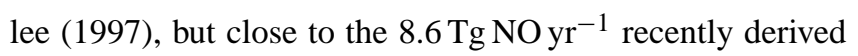
by Steinkamp and Lawrence (2011) using an updated version of the algorithm of Yieger and Levy (1995). The details of each ensemble member are given in Table 1, which also gives an overview of the sensitivity simulations. The time period over which each of the climatologies is assembled is also given.

Two sensitivity simulations are performed to allow assessment of the importance of C1-C3 BVOCs when compared to that of isoprene and the monoterpenes in terms of their effects on global tropospheric composition. These two sensitivity studies adopt the MACCity biogenic emission estimates and are thus comparable to the MEGAN simulation described above. We choose this emission inventory as this emission inventory as it is the most representative of the simulation year of 2000. For the NOBVOC simulation all C1C3 biogenic emission fluxes are set equal to zero. For the NOISOTERP simulation both the isoprene and monoterpene fluxes set equal to zero.

\subsection{Observations}

To provide a validation of the performance of the modified CB05 chemical mechanism applied in TM5, and to quantify the importance of the uncertainty introduced by BVOC emission estimates, we make use of a number of different observational datasets against which both individual and ensemble trace gas distributions are compared. Here we give a brief description of each of the measurement datasets used for this purpose.

The Measurement of OZone, water vapour, carbon monoxide and nitrogen oxides by Airbus In-service airCraft (MOZAIC) long-term measurement program provides tropospheric $\mathrm{O}_{3}$ profiles for a wide-range of different locations (Thouret et al., 1998). The sampling frequency is rather dependent on the location but provides measurements for under-sampled regions such as West and southern Africa, South America and India. The accuracy of the $\mathrm{O}_{3}$ measurements from MOZAIC have been shown to have an overall precision of \pm 2 ppb or $\sim 2 \%$ (Marenco et al., 1998). Here we use composites assembled from profiles taken at: Paris, France $\left(49.0^{\circ} \mathrm{N}, 2.6^{\circ} \mathrm{E}\right)$, Washington, USA $\left(38.9^{\circ} \mathrm{N}\right.$, $\left.77.5^{\circ} \mathrm{W}\right)$, Dakar, Senegal $\left(14.7^{\circ} \mathrm{N}, 17.5^{\circ} \mathrm{W}\right)$ and Seoul, South Korea $\left(37.5^{\circ} \mathrm{N}, 126.4^{\circ} \mathrm{E}\right)$. The choice of airports for 
which comparisons were made was constrained by the availability of a sufficient number of independent profile measurements for season June-July-August (JJA), where it should be noted that the majority of the locations for which measurements were available for 2000 are in the NH. The location of each airport for which comparisons are made is shown in Fig. 1.

The European Monitoring and Evaluation Program (EMEP, www.emep.int) has an established record of monitoring a host of different trace gases at the surface including tropospheric $\mathrm{O}_{3}$, alkanes, alkenes and isoprene. Stations are situated throughout Europe $\left(35-70^{\circ} \mathrm{N}, \sim 10^{\circ} \mathrm{W}-35^{\circ} \mathrm{E}\right)$ with sampling at both sea level (which are sensitive to local emission sources) and at more elevated altitudes (which are more representative of the Free Troposphere (FT)). For tropospheric $\mathrm{O}_{3}$, measurements are made every hour at a large number of measurement locations. The coverage is almost daily resulting in a statistically robust dataset against which comparisons can be made. For the low molecular weight organics such as $\mathrm{C}_{2} \mathrm{H}_{4}$, measurements are only available at $\sim 10$ stations from the entire EMEP network, which results in rather limited spatial coverage although over an extensive latitudinal range. The specific type of locations of these EMEP stations is diverse, ranging from Utö (Finland; $59.5^{\circ} \mathrm{N}, 21.2^{\circ} \mathrm{E}$ ) located on an island in the middle of the Baltic Sea, Donon (France; $48.3^{\circ} \mathrm{N}, 7.8^{\circ} \mathrm{E}$ ) in a forested mountain region, Campisabalos (Spain; $41.1^{\circ} \mathrm{N}$, $3.8^{\circ} \mathrm{W}$ ) which is located on a high plain away from local vegetation and Zingst (Germany; $54.4^{\circ} \mathrm{N}, 12.7^{\circ} \mathrm{E}$ ) which is located on a Peninsula surrounded by grassland and meadows. The diurnal sampling of the organics is also limited, where measurements are either made around once a day (at local noon) or provided as an average over the whole day, depending on the instrumentation used. There are typically 5-10 days worth of measurements made every month at each particular EMEP station. Although this is not as robust as the tropospheric $\mathrm{O}_{3}$ measurements it is still sufficient to analyse the variability in the seasonal cycle of $\mathrm{C} 2-\mathrm{C} 3$ organics across Europe. By assembling monthly mean values from the available observations we use these measurements to assess whether TM5 can capture both the seasonal cycle and mixing ratios for the European Domain. Unfortunately no measurements of $\mathrm{CH}_{3} \mathrm{COCH}_{3}$ are available.

The long term ground based flask measurements performed by the NOAA Earth System Research Laboratory (ESRL) Global Monitoring Division (GMD) provides a valuable record of changes in abundant long-lived trace gas species such as $\mathrm{CO}$ and $\mathrm{CH}_{4}$ (Novelli et al., 1998, 2003). The measurement sites are situated at many different locations, usually well away from strong local anthropogenic emission sources. They are therefore considered to be representative of the chemical background, although the long-range transport of air-masses containing emission signatures can occur especially for sites located in the outflow regions of major continents. In this study we exploit measurements of $\mathrm{CO}$ taken across a wide latitudinal range situated on the continents, in the marine boundary layer (MBL) and at high altitudes. The location of the 16 GMD stations selected from the entire record are shown in Fig. 1. The monthly mean composites from the observations are assembled from typically 10-20 days of flask samples taken each month. To ensure a valid comparison only those days where measurements are available are used to assemble the model monthly mean values. The height of each measurement station is also accounted for when interpolating the model output to avoid problems with orthography.

Finally, the first phase of the Civil Aircraft for Regular Investigation of the Atmosphere Based on an Instrument Container (CARIBIC) project ran between 1997 and 2001, where both $\mathrm{CO}$ and $\mathrm{O}_{3}$ were measured in-flight on passenger aircraft on routes from Dusseldorf $\left(51.4^{\circ} \mathrm{N}, 6.8^{\circ} \mathrm{E}\right)$ and Munich $\left(48.4^{\circ} \mathrm{N}, 11.8^{\circ} \mathrm{E}\right)$ in Germany to destinations such as Male $\left(4.2^{\circ} \mathrm{N}, 73.7^{\circ} \mathrm{E}\right)$ in the Maldives and Cape Town $\left(33.6^{\circ} \mathrm{S}, 18.4^{\circ} \mathrm{E}\right)$ in South Africa (Zahn et al., 2002). For $\mathrm{O}_{3}$ the uncertainty is either 4 ppbv or $4 \%$ of the total concentration, whichever is the highest (Zahn et al., 2002) and for $\mathrm{CO}$ the uncertainty is $\sim 3 \mathrm{ppb}$ for $\mathrm{CO}$ mixing ratios between 30-200 ppb (Brenninkmeijer et al., 2001). Here we use selected measurements made on flights for the year 2000 between Munich and Male, the Maldives or Frankfurt and Windhoek, Namibia for evaluation of the uncertainty introduced in the upper troposphere-lower stratosphere (UTLS). The flight tracks along which the in-situ measurements were made are shown in Fig. 1.

\section{Comparison of biogenic emission inventories}

In this section we examine the differences in the seasonal cycles for a number of different BVOC emission fluxes both at global and regional scales. Although similar annual comparisons have been performed for both Anthropogenic and BB emission inventories for the period 1980-2010 (Granier et al., 2011) comparisons of the biogenic component have received little attention. For this purpose we define five specific emission regions which cover a wide latitudinal range. Figure 1 gives an overview of the area covered by each of these regions, which are namely: Europe $\left(10^{\circ} \mathrm{W}-40^{\circ} \mathrm{E}, 36^{\circ} \mathrm{N}-\right.$ $\left.70^{\circ} \mathrm{N}\right)$, the US $\left(70^{\circ} \mathrm{W}-128^{\circ} \mathrm{W}, 30^{\circ} \mathrm{N}-48^{\circ} \mathrm{N}\right)$, South America $\left(33^{\circ} \mathrm{W}-82^{\circ} \mathrm{W}, 56^{\circ} \mathrm{S}-8^{\circ} \mathrm{N}\right)$, Africa $\left(20^{\circ} \mathrm{W}-38^{\circ} \mathrm{E}, 30^{\circ} \mathrm{S}-\right.$ $\left.30^{\circ} \mathrm{N}\right)$ and South-East Asia $\left(92^{\circ} \mathrm{E}-160^{\circ} \mathrm{E}, 10^{\circ} \mathrm{S}-20^{\circ} \mathrm{N}\right)$. The differences between the source segregated global emission estimates applied in each of the simulations are shown in Table 2, along with the 1- $\sigma$ variability of the mean value (converted to a percentage by normalising against the mean value). As shown in Table 2, large differences exist between the various emission estimates of biogenic species such as isoprene, the terpenes, $\mathrm{CO}, \mathrm{C}_{2} \mathrm{H}_{4}, \mathrm{CH}_{3} \mathrm{COCH}_{3}$ and $\mathrm{CH}_{3} \mathrm{OH}$. For the other BVOC species differences are limited to a few $\mathrm{TgC}_{\mathrm{Cr}}{ }^{-1}$. For most of the organic species the 


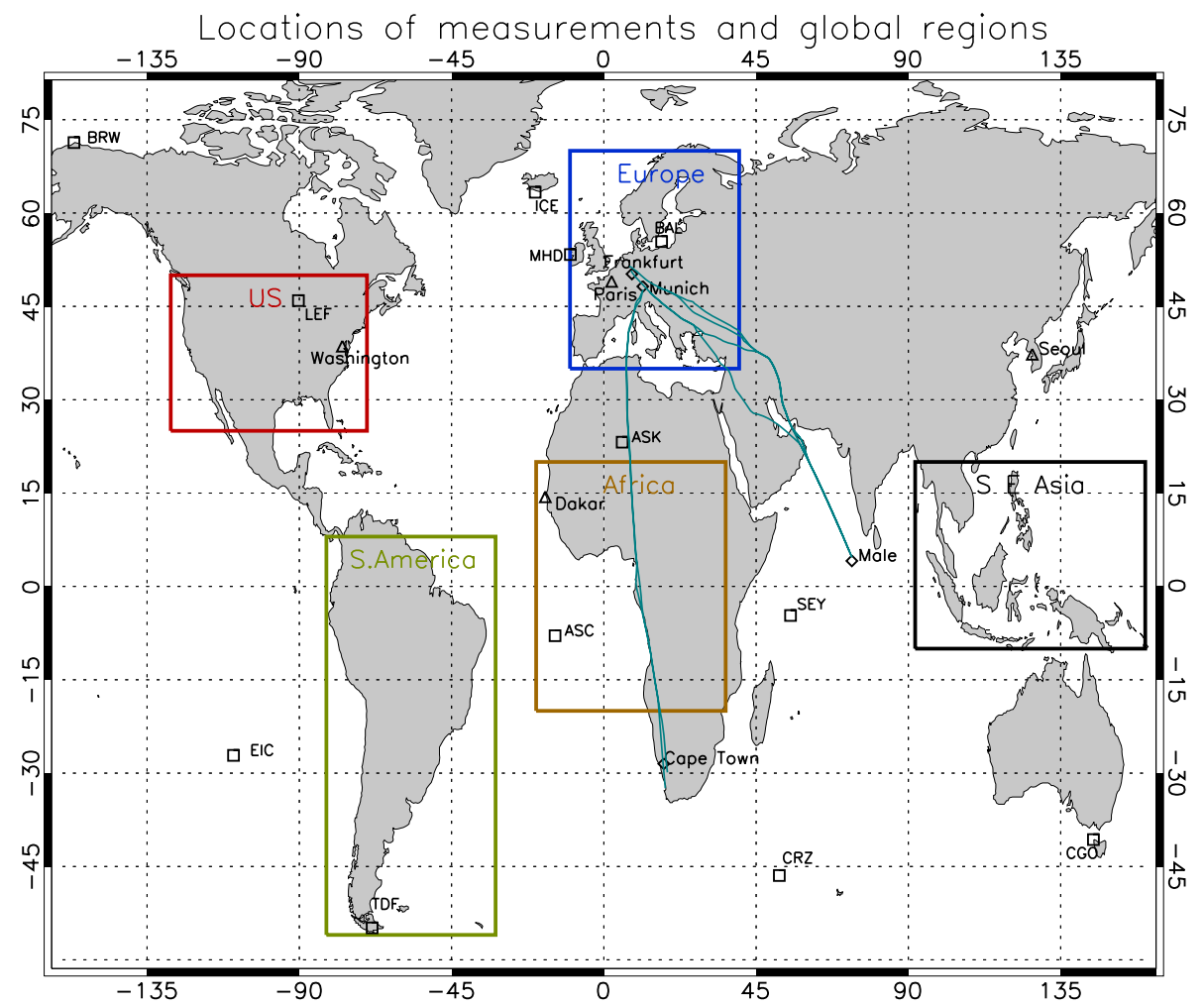

Fig. 1. Definition of global regions used for analysis of the differences in the global biogenic emission climatologies. Also shown are the location of the sampling sites for the measurements used in the study from MOZAIC ( $\Delta$ ), GMD ( $\square$ ), CARIBIC (metallic blue lines). For clarity the EMEP stations used are not shown by reside on mainland Europe in Finland, Germany, France and Spain.

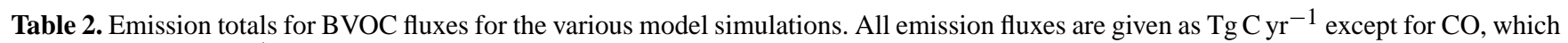
is given as $\mathrm{TgCO} \mathrm{yr}^{-1}$, along with the relative variability with respect to the ensemble mean emissions. The corresponding anthropogenic and biomass burning emissions fluxes are also given. Other details: ${ }^{1}$ Taken from Lathiere et al. (2006), ${ }^{2}$ taken from Lamarque et al. (2010), ${ }^{3}$ Estimated as $10 \%$ of $\mathrm{CH}_{3} \mathrm{OH}$ emission.

\begin{tabular}{lccccccc}
\hline BVOC trace species & ORCH & MEGAN & EMAC & POET & $\begin{array}{c}\text { Relative 1- } \sigma \\
\text { variation }(\%)\end{array}$ & RETRO-REAS & GFEDv3 \\
\hline $\mathrm{CO}$ & 179.5 & 96.1 & 120.4 & 196.5 & 32.1 & 546.2 & 265.7 \\
$\mathrm{CH}_{3} \mathrm{OH}$ & 106.1 & 56.7 & 61.9 & 88.0 & 29.6 & 5.6 & 3.3 \\
$\mathrm{HCOOH}$ & 1.5 & $1.5^{1}$ & 1.5 & $1.5^{1}$ & N/A & 1.3 & 0.8 \\
$\mathrm{CH}_{2} \mathrm{O}$ & 25.3 & 4.0 & $4.0^{2}$ & $4.0^{2}$ & 114.2 & 1.1 & 3.8 \\
$\mathrm{C}_{2} \mathrm{H}_{4}$ & 9.8 & 15.4 & 10.7 & 5.6 & 38.7 & 5.6 & 3.3 \\
$\mathrm{C}_{2} \mathrm{H}_{6}$ & 0.8 & 0.9 & 0.4 & 1.6 & 54.0 & 4.4 & 1.5 \\
$\mathrm{C}_{2} \mathrm{H}_{5} \mathrm{OH}$ & $10.6^{3}$ & $5.7^{3}$ & $6.2^{3}$ & $8.8^{3}$ & 29.3 & 0.3 & 0.2 \\
$\mathrm{CH}_{3} \mathrm{CHO}$ & 14.7 & 6.1 & $6.1^{2}$ & $6.1^{2}$ & 52.1 & 1.1 & 0.8 \\
$\mathrm{CH}_{3} \mathrm{COOH}$ & 7.2 & $7.2^{1}$ & 1.4 & $7.2^{1}$ & 50.4 & 1.9 & 3.4 \\
$\mathrm{C}_{3} \mathrm{H}_{6}$ & 1.3 & 6.5 & 3.0 & 1.8 & 74.4 & 2.7 & 1.8 \\
$\mathrm{C}_{3} \mathrm{H}_{8}$ & 1.1 & 1.1 & 0.3 & 1.8 & 57.0 & 2.3 & 0.9 \\
$\mathrm{CH}_{3} \mathrm{COCH}$ & 42.6 & 17.7 & 25.6 & 15.5 & 48.5 & 3.5 & None \\
$\mathrm{TERPENES}_{\text {ISOPRENE }}^{127.4}$ & 85.3 & $85.3^{2}$ & 129.8 & 23.4 & None & 0.2 \\
\hline
\end{tabular}


contribution from biogenic emission sources is important, accounting for between $\sim 40-90 \%$ of the global annual emission fluxes for each individual species. In some exceptional cases biogenic activity acts as the dominant global emission source e.g. $\mathrm{CH}_{3} \mathrm{COCH}_{3}$.

For brevity we limit the comparison in this section to a few key C1-C3 organic species, since the differences in e.g. global isoprene and terpene emissions have already received some attention in the literature (e.g. Arneth et al., 2008; Williams et al., 2009; Zare et al., 2012). Figure 2a-d shows the seasonal climatological cycles for $\mathrm{CO}, \mathrm{C}_{2} \mathrm{H}_{4}, \mathrm{C}_{2} \mathrm{H}_{6}$ and $\mathrm{CH}_{3} \mathrm{COCH}_{3}$ for each of the four chosen BVOC inventories (solid lines) both globally and for each of the five pre-defined regions. To highlight the importance of BVOC emissions for certain regions we also show the corresponding anthropogenic (RETRO) and BB emission (GFEDv3) components applied in the simulations as dashed lines. Comparing the different biogenic emission estimates shows that there is a considerable difference in the monthly emission fluxes between the 4 climatologies for some species (e.g. CO), whereas for some other species there is some similarity between different climatologies (e.g. $\mathrm{C}_{2} \mathrm{H}_{4}$ between ORCHIDEE and EMAC). It is interesting to see that the BVOC inventory which displays the highest global biogenic emission flux for e.g. $\mathrm{CO}$ does not necessarily also have the highest global emission fluxes for all other BVOC species. This could be due to the use of different classifications of vegetation and/or productivity factors. For the NH there is a strong seasonal cycle in all biogenic emissions related to the variability in the temperature driven biogenic activity, with emission fluxes being highest during JJA. For the tropical regions no such seasonal cycle exists, with the enhancements during the respective monsoon periods being relatively weak (e.g. Africa during JJA). In the tropics a strong seasonality exists in the BB emissions, where during the most intense burning periods BB acts as the most dominant source of most of the trace species shown, although it should be noted that the $\mathrm{BB}$ contributions for $\mathrm{CH}_{3} \mathrm{COCH}_{3}$ have been scaled up by an order of magnitude to aid clarity. Apart from $\mathrm{CO}$ it can be seen that the anthropogenic component (dashed red line, RETRO) is typically much smaller than the corresponding biogenic component for all 4 organic species shown. It is interesting to note that the only seasonal cycle in the anthropogenic component exists in Europe, where there is a slight decrease during the summer months thus being anti-correlated with the seasonal cycle in the biogenic component.

\section{The influence of BVOC emissions on global tropospheric composition}

Here we examine the influence that the emission of C1-C3 BVOC species has on the distribution of tropospheric $\mathrm{O}_{3}$ and $\mathrm{CO}$ at the global scale. Previous studies concerned with biogenic emissions have principally focused on the effect that the chemical oxidation of isoprene has on either regional air quality (e.g. Simpson, 1995; Roberts et al., 2006; Hewitt et al., 2011) or the composition of the global troposphere (e.g. von Kuhlmann et al., 2004; Folberth et al., 2006; Fiore et al., 2011). By exploiting the sensitivity studies described in Sect. 2, we also determine how important the smaller organics of biogenic origin are towards global oxidative capacity and place it in context compared to isoprene and the monoterpenes. To the authors knowledge no focus has yet been placed on the cumulative impact of the BVOC species in the literature, other than specific studies related to isoprene, the monoterpenes and the sequiterpenes. A complete list of these species is given in Table 2.

Figure 3 shows the impact of BVOC C1-C 3 species on tropospheric $\mathrm{O}_{3}$ and $\mathrm{CO}$ in the LT for seasons DJF and JJA by comparing the NOBVOC simulation with the MEGAN simulation. Differences are shown for the LT only (defined as the averaged changes between the surface and $750 \mathrm{hPa}$ ). Here the effects will be maximal due to the emission sources being predominantly located at the surface, except for isoprene in the tropics which is emitted in the first $50 \mathrm{~m}$ of the atmosphere (Huijnen et al., 2010). To provide some confidence in the performance of the modified CB05 chemical mechanism an extensive validation against surface concentrations for both species is presented later on in Sect. 5. From Fig. 3 it can be seen that the impact of C1-C3 BVOCs on $\mathrm{O}_{3}$ in the LT ( $\sim 0-5 \%$ enhancements) is approximately a third of the impact on $\mathrm{CO}(\sim 0-20 \%$ enhancements), where a strong seasonal signature exists in the latitudinal distribution of the differences for both trace species as a result of both the seasonal cycle in BVOC emissions in the $\mathrm{NH}$ and the seasonal variation in photochemical activity. The relative influence of biogenic emissions for $\mathrm{CO}$ minimizes in regions with large local BB emissions (equatorial Africa) and anthropogenic emissions (south-east Asia) as would be expected considering that BB acts as a dominant source of trace gases during the respective burning seasons.

From Fig. 3 it can be seen that maximal increases in LT $\mathrm{O}_{3}$ of between $3-4 \%$ occur over the tropical source regions $\left(20^{\circ} \mathrm{S}-20^{\circ} \mathrm{N}\right)$ and in the tropical remote MBL. Here there is a clear signal along the Inter-Tropical Convergence Zone (ITCZ) related to the high humidity and perturbations introduced into the $\mathrm{HO}_{\mathrm{x}}$ cycle (see below). For $\mathrm{CO}$ maximal increases of between $\sim 12-15 \%$ occur at continental scale during JJA. These increases extend over the entire $\mathrm{SH}$ as a result of $\mathrm{CO}$ having a longer atmospheric lifetime than $\mathrm{O}_{3}$. The extent of propagation of the effects on $\mathrm{CO}$ mixing ratios away from the source regions will be affected by the $\mathrm{CO} / \mathrm{N}$ ratio provided in the cumulative emission totals applied for each biogenically active region. This is similar to that observed for both anthropogenic and BB emissions (Dalsøren and Isaksen, 2006; Williams et al., 2012b). For biogenic emissions this is defined as the ratio between biogenic $\mathrm{CO}$ emissions and the soil $\mathrm{NO}_{\mathrm{x}}$ component. For soil $\mathrm{NO}_{\mathrm{x}}$ the global estimates range from 6-21 $\mathrm{Tg} \mathrm{N} \mathrm{yr}^{-1}$ (Davidson and Kringerlee, 

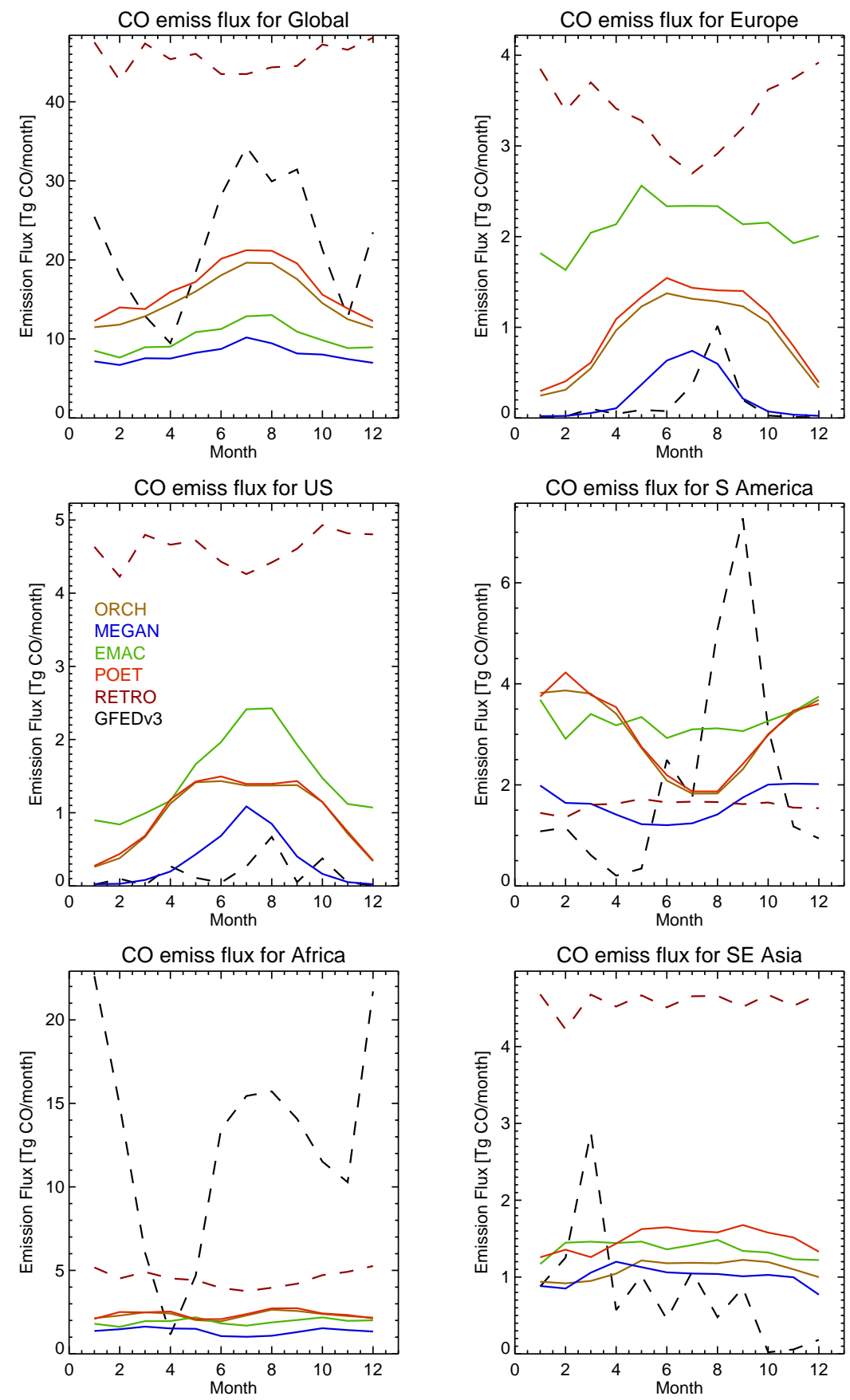

Fig. 2a. The seasonal cycle for CO emissions from 4 biogenic climatologies (solid lines), anthropogenic origin (RETRO, red dashed line), and biomass burning from GFEDv3 (dashed line) at global (top left) and regional (other panels) scales. The colour key is given in the inset of one of the panels.

1997), where the impact of biogenic $\mathrm{NO}_{\mathrm{x}}$ fluxes becomes most important in more remote regions away from other strong emission sources.

To understand which chemical processes are responsible for inducing the changes in these key tropospheric trace species we analyse the global annual chemical budget terms between the MEGAN and NOBVOC simulations for the year
2000. For tropospheric $\mathrm{O}_{3}$ the recycling of $\mathrm{NO}_{\mathrm{x}}$ via the $\mathrm{HO}_{2}$ channel decreases by $\sim 4 \%$, which results in the net production term decreasing more than the net destruction term due to $\mathrm{OH}$. This is a direct effect of the reduction in tropospheric $\mathrm{CO}$, where $\mathrm{HO}_{2}$ is formed from the chemical oxidation of CO as described in TM5 (Huijnen et al., 2010). For tropospheric $\mathrm{CO}$ the decreases result from the cumulative 

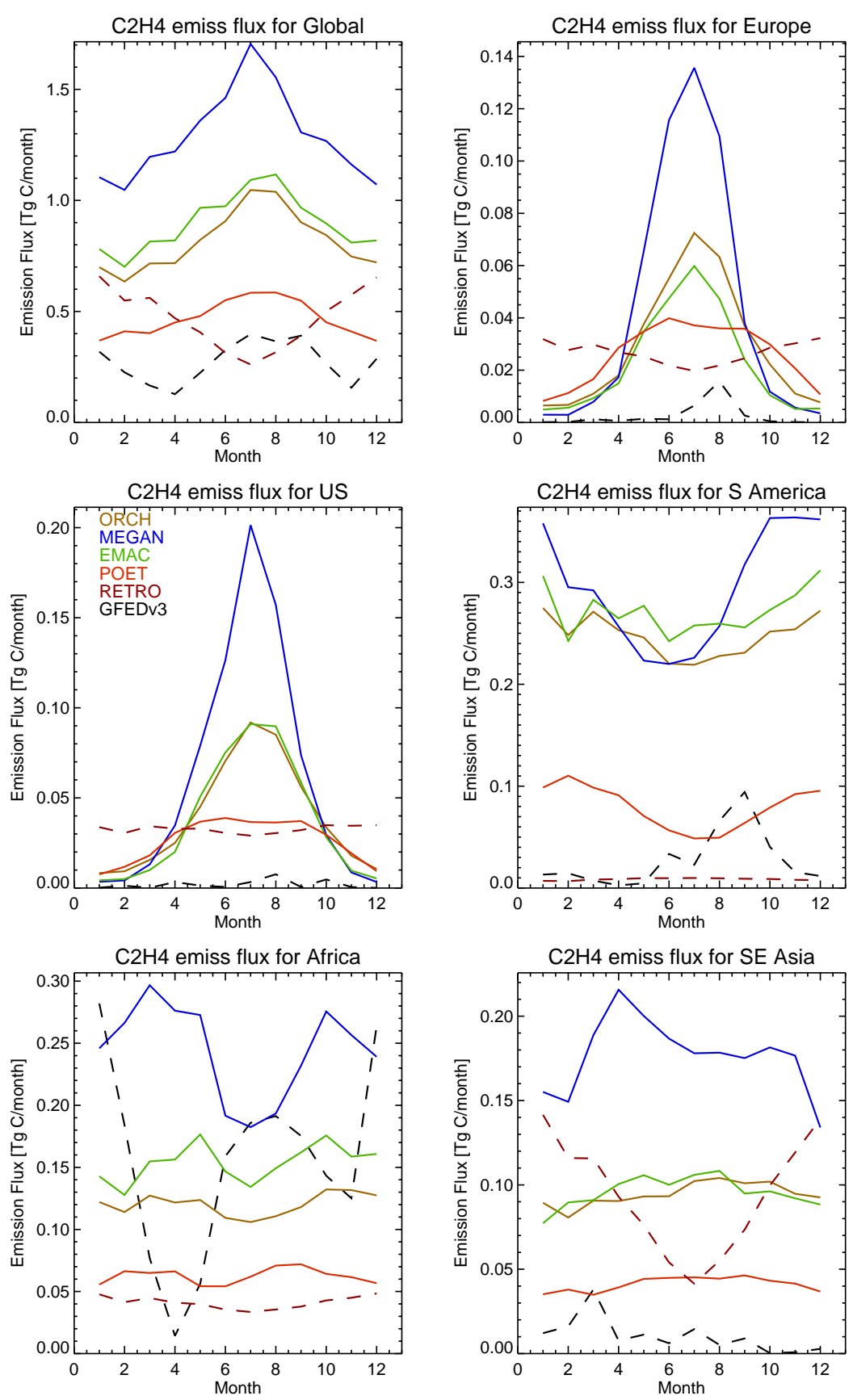

Fig. 2b. As for Fig. 2a except for $\mathrm{C}_{2} \mathrm{H}_{4}$.

reduction in the direct emissions of $\mathrm{CO}(\sim 9 \%)$ and the direct in-situ chemical production terms $(\sim 5.5 \%)$. This decrease in the direct in-situ chemical production terms is due to a decrease in $\mathrm{HCHO}$ mixing ratios, where the photo-oxidation of $\mathrm{HCHO}$ acts as the dominant chemical source term of $\mathrm{CO}$ in the troposphere. As well as a reduction in the direct emission of $\mathrm{HCHO}$ by $\sim 62 \%\left(\sim 5 \mathrm{Tg} \mathrm{yr}^{-1}\right)$ in the NOBVOC simulation, the large decrease in $\mathrm{CH}_{3} \mathrm{OH}$ emissions also dampens the in-situ photochemical production of $\mathrm{HCHO}$ significantly.

This finding could have implications for the use of $\mathrm{HCHO}$ as a proxy for determining isoprene emissions from satellite measurements (Palmer et al., 2003; Marias et al., 2012), where non-isoprene BVOC emissions will be co-located with areas exhibiting high isoprene emissions (e.g. in tropical rainforests, woodlands and boreal forests). By utilizing a CTM in a similar way to that performed in this study such a bias could be corrected for, resulting in improved constraints and reduced regional biases for isoprene emissions. 

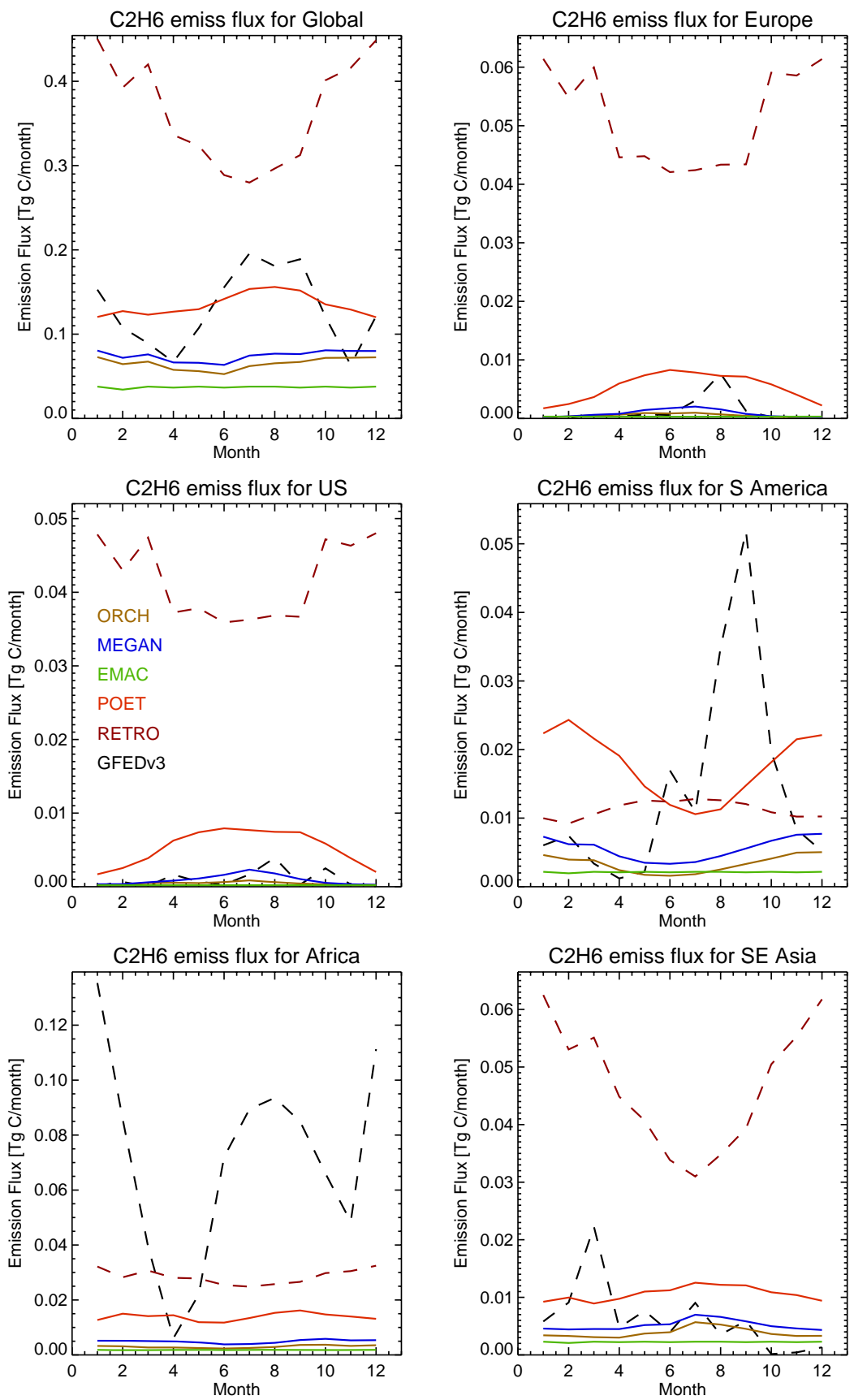

Fig. 2c. As for Fig. 2a except for $\mathrm{C}_{2} \mathrm{H}_{6}$.

In Table 3 we present the changes in the global tropospheric burdens for $\mathrm{O}_{3}, \mathrm{CO}$ and $\mathrm{CH}_{4}$ for the year 2000 ( $\mathrm{BCO}, \mathrm{BO}_{3}$ and $\mathrm{BCH}_{4}$, respectively), along with the atmospheric lifetimes for $\mathrm{CO}$ and $\mathrm{CH}_{4}\left(\tau \mathrm{CO}\right.$ and $\tau \mathrm{CH}_{4}$, respectively). Values are shown for the MEGAN, NOBVOC and NOISOPTERP simulations. For defining the tropopause we use the $150 \mathrm{ppb}$ contour for $\mathrm{O}_{3}$ proposed in Stevenson et al. (2006). It is assumed that there is no change in the total mass of the troposphere due to the changes in tropospheric
$\mathrm{O}_{3}$ being relatively small around $100-200 \mathrm{hPa}$ (see Sect. 5). Overall the impact of BVOC C1-C3 compounds is approximately one third that of the combined impact from isoprene and monoterpenes, meaning that the effects are significant at the global scale. Table 3 shows that there is a decrease in BCO of $\sim 37 \mathrm{Tg}$ CO for NOBVOC and $\sim 114 \mathrm{Tg} \mathrm{CO}$ for NOISOPTERP i.e. BVOC C1-C3 compounds exert $\sim 30 \%$ of the influence of that of isoprene and the monoterpenes. There is also a corresponding decrease in $\mathrm{BO}_{3}$ of $\sim 8 \mathrm{Tg}_{3}$ 

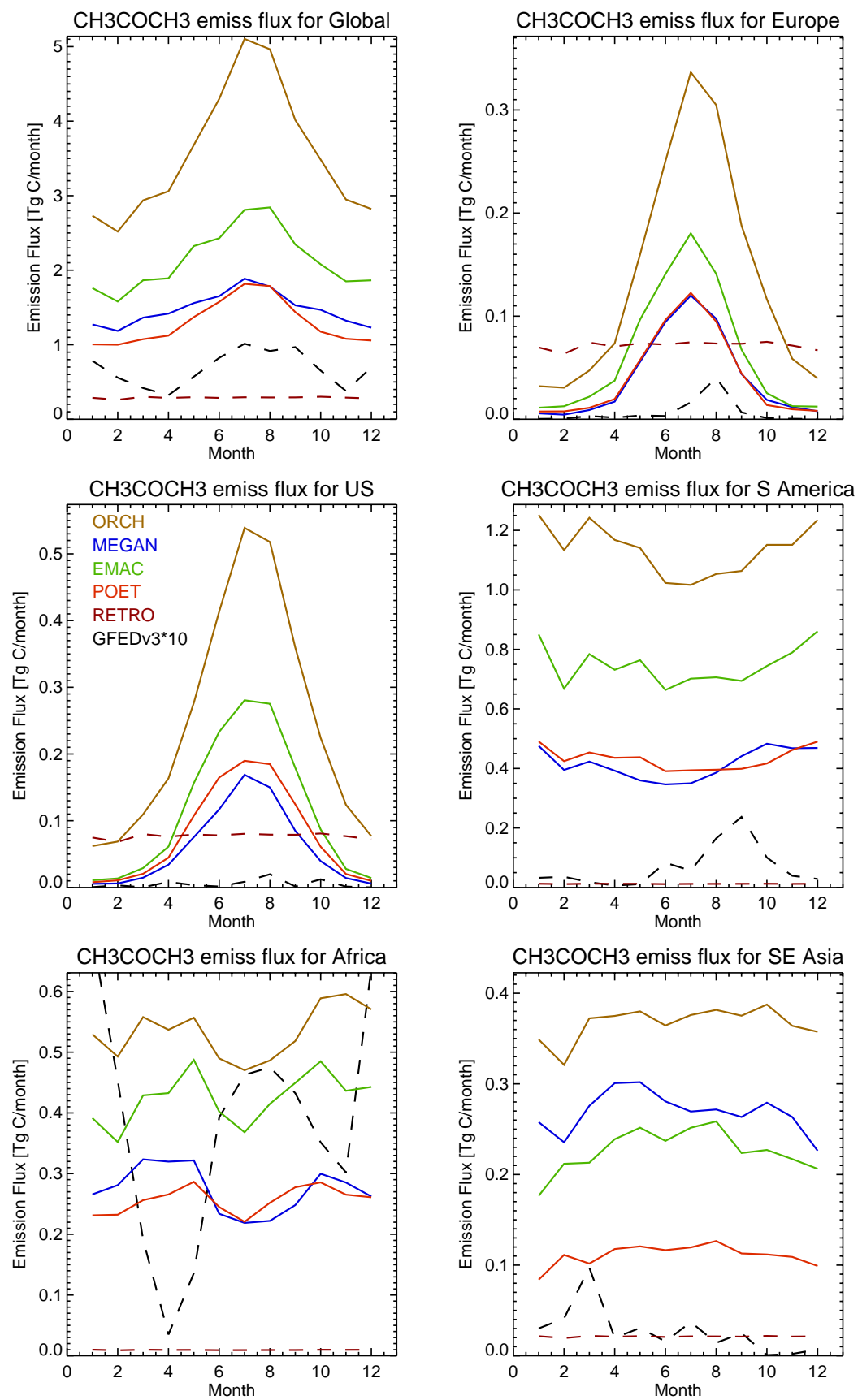

Fig. 2d. As for Fig. 2a. except for $\mathrm{CH}_{3} \mathrm{COCH}_{3}$. Note that in these panels the biomass burning contribution scaled up by 10 .

for NOBVOC and $29 \mathrm{Tg} \mathrm{O}_{3}$ for NOISOTERP. In spite of this reduction in $\mathrm{BO}_{3}$ (and thus $\mathrm{OH}$ ), $\tau \mathrm{CO}$ also decreases in both simulations, showing that the reduction in (pseudo) $\mathrm{CO}$ emissions dominates the reduction in $\mathrm{OH}$ with respect to BCO. For $\tau \mathrm{CH}_{4}$ there are significant decreases of $\sim 8 \%$ for NOBVOC and $\sim 19 \%$ for NOISOPTERP due to the significant reduction in $\mathrm{BCO}$ allowing more $\mathrm{OH}$ to be scavenged by $\mathrm{CH}_{4}$. This shows that improving the accuracy and interannual variability in BVOC emission estimates is an important step towards understanding the recent variability in the growth rate of atmospheric $\mathrm{CH}_{4}$.

\section{The variability in the distribution of the principal BVOC species}

For the purpose of evaluating the performance of the modified CB05 chemical mechanism in TM5, and to quantify the variability introduced into the large-scale chemical 

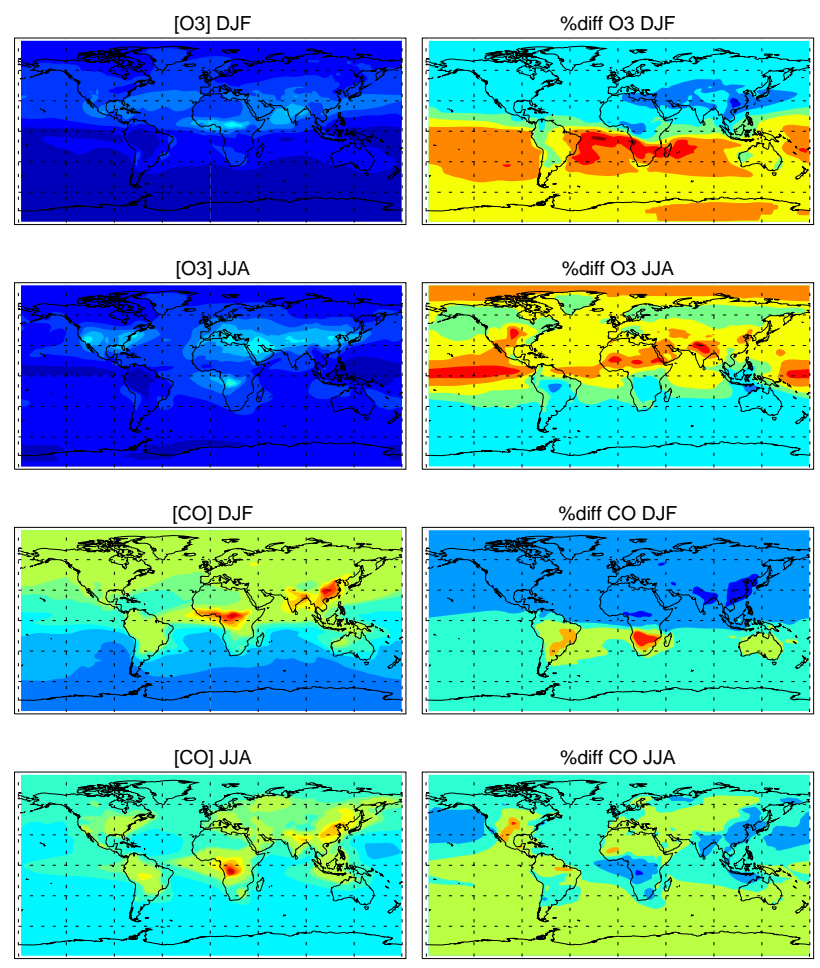

$\mathrm{ppb}$

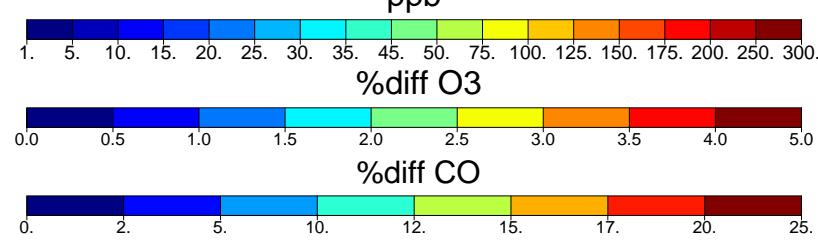

Fig. 3. Simulated seasonal mean distributions of $\mathrm{O}_{3}$ and $\mathrm{CO}$ mixing ratios in the lower troposphere (surface to $750 \mathrm{hPa}$ ) for seasons DJF and JJA (left panels) for the MEGAN simulations. The right panels show the corresponding relative contribution of C1-C3 BVOC emissions to the simulated global distributions (right panels). The relative differences shown on the right are calculated using (MEGANNOBVOC)/MEGAN.

simulations by using different emission estimates from biogenic processes, we make comparisons of the co-located model output against a number of different observational datasets that have been introduced in Sect. 2.3. Rather than comparing the individual agreement from each of the simulations we use the model ensemble mean, with the variability across all simulations being represented by using the $1-\sigma$ spread in the ensemble mean. Due to a lack of global measurements for organic species such as $\mathrm{CH}_{3} \mathrm{OH}$ and the alkanes we principally focus on the distributions of tropospheric $\mathrm{O}_{3}$ and $\mathrm{CO}$, although we also exploit the EMEP measurement network which provides regular observations for some species such as $\mathrm{C}_{2} \mathrm{H}_{4}$ and $\mathrm{C}_{2} \mathrm{H}_{6}$.

\subsection{Tropospheric $\mathrm{O}_{3}$}

Figure 4 shows comparisons of tropospheric $\mathrm{O}_{3}$ in Europe against measurements taken as part of the EMEP measurement network. The sampling occurs throughout the day every hour thus capturing the diurnal cycle in $\mathrm{O}_{3}$ mixing ratios. For the analysis presented here these are then aggregated into monthly mean values using observations made every $3 \mathrm{~h}$ so as to be comparable with the output frequency applied in TM5. The altitude of each sampling station is accounted for when calculating the monthly mean values in TM5 and the position of each station used to weight model values with those contained in neighbouring grid-cells so as to provide some variability of values throughout each particular grid cell. The selection of stations is such that those situated at high altitudes $(>1 \mathrm{~km})$ are excluded for calculating the observational monthly means. For brevity and to increase the area of the sampling domain we use monthly mean values assembled using measurements taken at a number of different stations in any one country shown. Comparisons are shown for a number of different European countries (namely Denmark, Poland, The Netherlands, Slovakia, Italy and Spain) which cover the latitude range of $\sim 35-55^{\circ} \mathrm{N}$ and longitudinal range of $\sim 2-20^{\circ} \mathrm{E}$. The choice of countries was limited by the availability of measurements in the EMEP network. For the observations both the monthly means and $1-\sigma$ variability are shown, whereas for TM5 we show the 1- $\sigma$ variability of the ensemble mean which provides us with a diagnostic to assess the associated uncertainty.

Figure 4 shows that TM5 captures the seasonal cycle across all chosen countries, where the agreement for individual months is generally quite good during DJF but tends to result in an over-estimation between July and September. Although not included in this study, when performing a similar simulation as ORCH but using the modified CBM4 mechanism (Houweling et al., 1998) reveals that the application of the modified CB05 mechanism only increases this overestimation in near-surface $\mathrm{O}_{3}$ by a few percent (not shown) and is thus not a major cause of the model bias shown in Fig. 4. Moreover, the over-estimation is also not due to the biogenic soil $\mathrm{NO}_{\mathrm{x}}$ component, which has been found to have a rather limited effect on European surface $\mathrm{O}_{3}$ (Simpson, 1995). The most likely cause is the cumulative effects of a lack of a diurnal or weekly variation in the $\mathrm{NO}_{\mathrm{x}}$ emissions from the road transport sector (Huijnen et al., 2010), missing deposition surface terms during summer (Ordñez et al., 2010) representation of nocturnal boundary layer dynamics or weak convective mixing out of the boundary layer. It is assumed that the anthropogenic $\mathrm{NO}_{\mathrm{x}}$ emission estimates in the RETRO inventory are realistic, where a recent intercomparison of various global anthropogenic inventories has shown the RETRO inventory to provide the lowest estimates of those inventories commonly adopted (Granier et al., 2011). Those countries for which the overestimation is most extreme are in Netherlands and Italy, equating to $\sim 10 \mathrm{ppb}$ in 

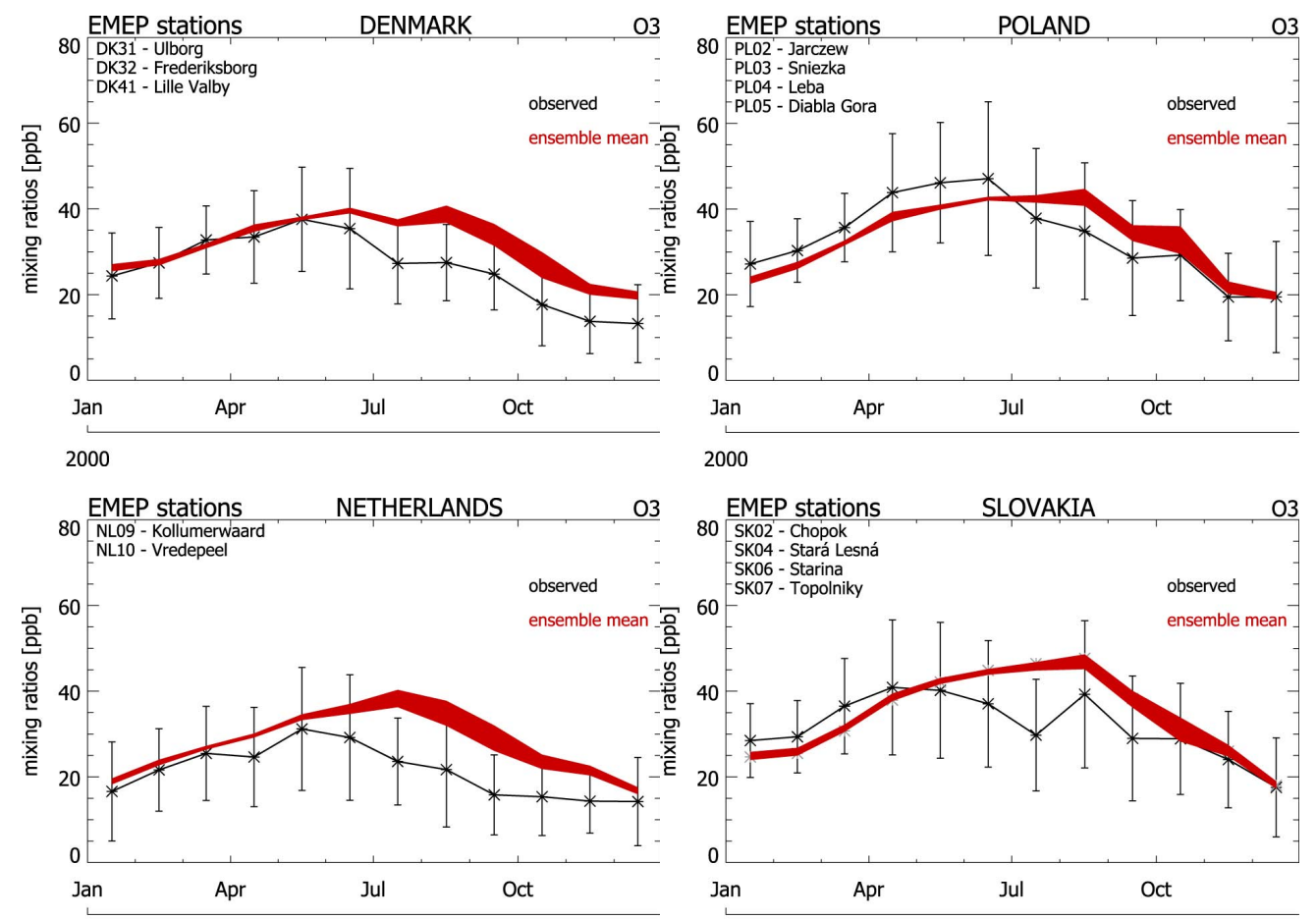

2000
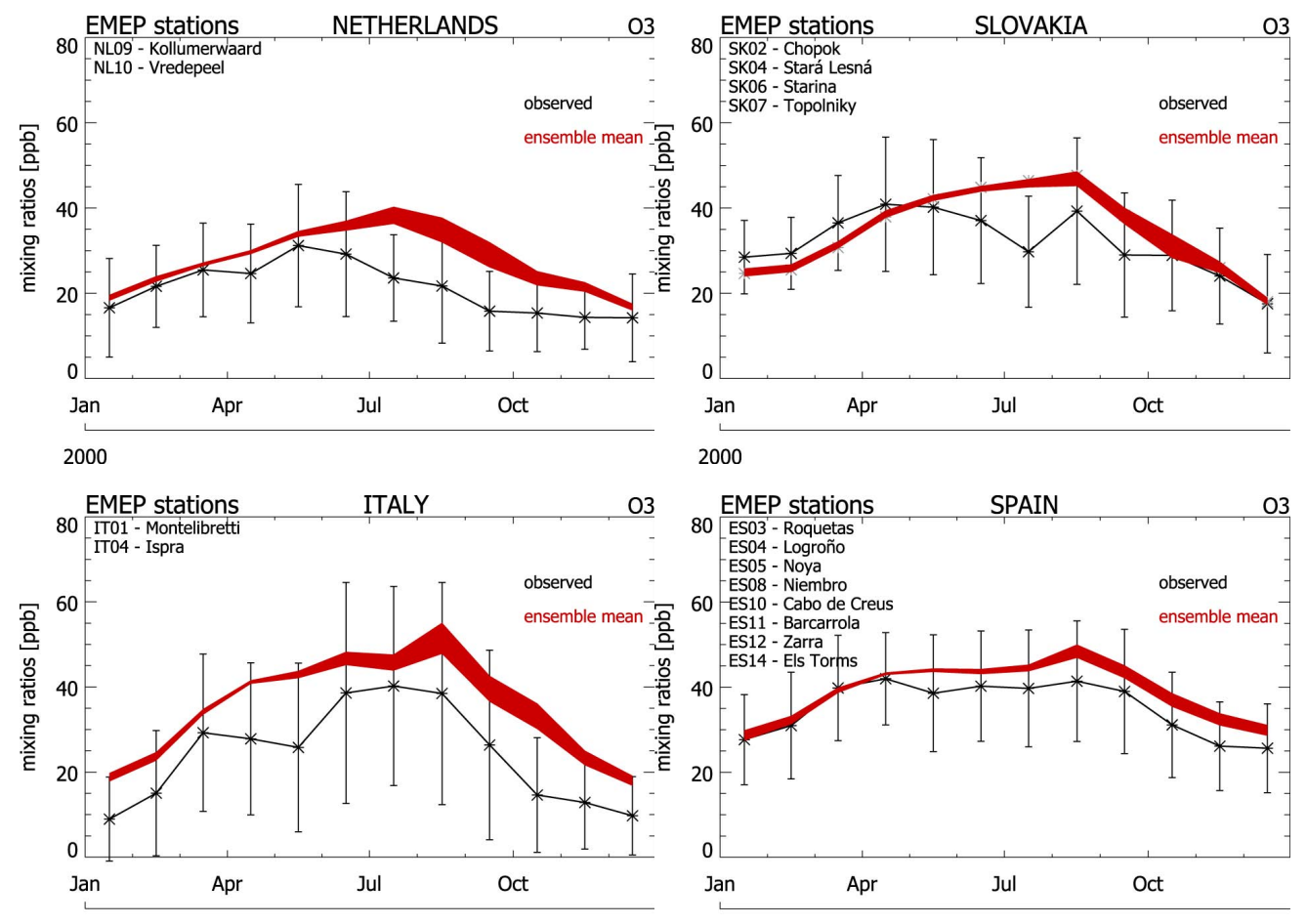

2000

2000

Fig. 4. The seasonal variability in surface $\mathrm{O}_{3}$ sampled at EMEP monitoring stations during 2000. Comparisons are made against the ensemble mean from the TM5 simulations against monthly averages derived for a number of different countries, namely: Denmark, Poland, The Netherlands, Slovakia, Italy and Spain. The stations used for each country composite are provided in each separate panel.

Table 3. The changes in the global tropospheric burdens and atmospheric lifetimes of $\mathrm{O}_{3}, \mathrm{CO}$ and $\mathrm{CH}_{4}$ for the year 2000 due to the emission of C1-C3 BVOC species and isoprene/monoterpenes. The burdens are given in Tg species. The lifetime of tropospheric $\mathrm{O}_{3}$ is equal to $\sim 24$ days across all simulations. For $\mathrm{CH}_{4}$ we assume a fixed soil sink of $30 \mathrm{Tg} \mathrm{yr}^{-1}$. The percentage differences for the various diagnostics are given when compared with the MEGAN simulation, which applies all BVOC emissions. The troposphere is defined using the method defined in Stevenson et al. (2006). All burdens are given in Tg species.

\begin{tabular}{lcrr}
\hline Diagnostic & MEGAN & NOBVOC & NOISOPTERP \\
\hline $\mathrm{BCO}$ & 331.0 & $295.0(-10.9 \%)$ & $217.3(-34.4 \%)$ \\
$\mathrm{BO}_{3}$ & 312.7 & $304.9(-2.5 \%)$ & $283.7(-6.9 \%)$ \\
$\mathrm{BCH}_{4}$ & 4861.65 & $4860.12(-0.1 \%)$ & $4849.64(-0.3 \%)$ \\
$\mathrm{CO}$ tropospheric lifetime (days) & 51 & $49(-4.4 \%)$ & $41(-19.5 \%)$ \\
$\mathrm{CH}_{4}$ atmospheric lifetime (years) & 8.99 & $8.67(-7.5 \%)$ & $7.62(-18.8 \%)$ \\
\hline
\end{tabular}



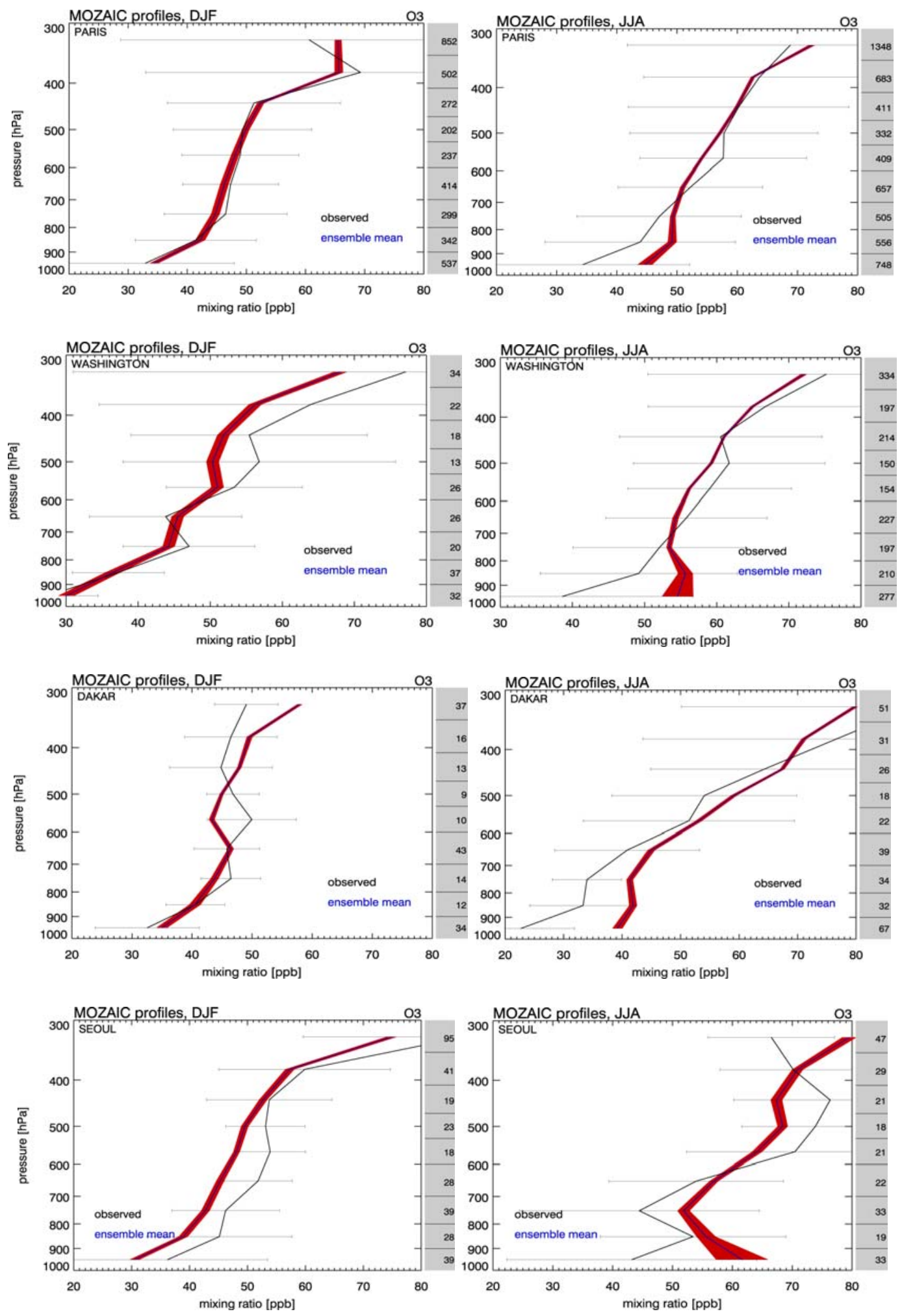

Fig. 5. Seasonal comparisons of tropospheric $\mathrm{O}_{3}$ profiles measured as part of the MOZAIC measurement program against the 1- $\sigma$ deviation (red) in the ensemble model mean from the TM5 simulations. The ensemble mean value is shown as the blue line. The error bars on the measurements represent the $1-\sigma$ deviation in the seasonal mean. 
the monthly mean $\mathrm{O}_{3}$ mixing ratios. Both countries exhibit high background $\mathrm{NO}_{\mathrm{x}}$ emissions from anthropogenic sources (e.g. Castellanos and Boersma, 2012) which generally result in too efficient photo-chemical $\mathrm{O}_{3}$ production in TM5.

Examining the magnitude of the variability in the seasonal cycle displayed in the spread of the $1-\sigma$ deviation from the ensemble model mean shows that for the north-eastern and north-western countries (Denmark, Poland, Slovakia and the Netherlands) the maximum uncertainty introduced by BVOC emissions occurs during the boreal summer and autumn, where biogenic fluxes are highest. This uncertainty equates to $\sim 10-20 \%$ of the resident mixing ratios in surface $\mathrm{O}_{3}$ and shows that biogenic BVOC emission estimates are important for assessing air-quality, especially in northern Europe. Thus BVOC emissions even introduce a significant uncertainty for a densely populated region which is typically thought to be dominated by anthropogenic $\mathrm{VOC}$ and $\mathrm{NO}_{\mathrm{x}}$ emissions.

Figure 5 shows comparisons to seasonal composites of tropospheric $\mathrm{O}_{3}$ profiles taken as part of the MOZAIC measurement campaign for seasons DJF and JJA. The location of each of the airports is given in Sect. 2.3 and shown in Fig. 1. The measurements are binned on the same vertical grid as that used in the TM5 simulations, where the number of independent measurements that are used for each vertical bin is shown in the grey shaded section at the side of each panel. The seasonal composites are assembled from flights that take off throughout the day providing some representativity of the diurnal cycle which occurs. In general the gradient in the profiles of the seasonal composites is captured well during DJF, especially at Paris. At Dakar in DJF the vertical gradient is rather shallow, where there is good agreement between the ensemble mean and measurements in the boundary layer but a low correlation around $550 \mathrm{hPa}$ due to transport effects which are not captured in the ensemble model mean. For Seoul there is generally an under prediction in the integrated tropospheric $\mathrm{O}_{3}$ column for this season, possibly related to the REAS emission inventory which has recently been updated resulting in an increase in the anthropogenic $\mathrm{NO}_{\mathrm{x}}$ emissions from East Asia of over $40 \%$ (V. Huijnen, personnel communication, 2013).

For the JJA season the mixing ratios of $\mathrm{O}_{3}$ in the boundary layer are consistently higher in the TM5 ensemble in agreement with the conclusions of the EMEP comparisons shown above. Thus a similar bias during summertime occurs across a diverse range of locations regardless of the regional $\mathrm{NO}_{\mathrm{x}}$ regime (c.f. Paris versus Dakar). Differences in $\mathrm{LT} \mathrm{O}_{3}$ due to high local aircraft $\mathrm{NO}_{\mathrm{x}}$ emissions emitted around the airport are not captured well in TM5 due to the dilution of point sources when using a horizontal resolution of $3^{\circ} \times 2^{\circ}$ and the lack of daily variation in the frequency of air traffic. Accounting for sub-grid variability in NO mixing ratios would moderate $\mathrm{O}_{3}$ in the boundary layer by increasing titration during the night (Pison and Menut, 2004). One other possibility is that the mixing in the boundary layer during nighttime is also not captured well due to difficulties in capturing a shallow stable boundary layer in a global model with rather coarse resolution. It should also be noted that e.g. CO and VOC emissions from aircraft are also not accounted for in the simulations, although these are not thought to be dominant emission terms. In that there is a high model bias in the boundary layer results in the vertical gradient of the TM5 composites changing with respect to altitude. Once above $700 \mathrm{hPa}$ the agreement in the vertical gradient between the observations and the model ensemble agrees remarkably well.

Figure 5 also shows the associated uncertainty introduced as diagnosed using the 1- $\sigma$ variability in the ensemble mean. It can be seen that for season DJF there is a rather homogenous uncertainty introduced of between $1-2 \mathrm{ppb} \mathrm{O}_{3}$ throughout the troposphere. Thus the relative uncertainty decreases with respect to height as a result of increasing resident mixing ratios. For season JJA, when BVOC emissions are high, it can be seen that the degree of uncertainty introduced into the simulations is rather specific to the location of the airport. For Paris and Dakar there is only a marginal increase in the uncertainty introduced into the boundary layer compared to season DJF, whereas for both Washington and Seoul an uncertainty of 4-8 ppb is introduced equating to between $\sim 10-20 \%$ of the resident mixing ratios. This is in part due to variability in the regional importance of the BVOC component (not shown) and their non-linear reactivity with other emission sources. This provides further evidence that BVOC emissions can be important for simulating the distribution in $\mathrm{LT} \mathrm{O}_{3}$

\subsection{Alkanes and alkenes}

Figure 6 shows comparisons of the $1-\sigma$ deviation in the ensemble mean for the $\mathrm{C} 2$ and $\mathrm{C} 3$ alkanes and alkenes included in the modified CB05 mechanism against regular observations made at 4 different EMEP measurement sites: namely Utö (Finland), Zingst (Germany), Donon (France) and Campisabolos (Spain). These stations cover most of the latitudinal and climatological range of Europe. The model is sampled online by interpolating at each station location at $12 \mathrm{~h}$ noon every day using the same interpolation technique as that described for tropospheric $\mathrm{O}_{3}$ in Sect. 5.1. Moreover, sites are chosen such that the seasonal variation in both northern and southern Europe can be investigated. For more details related to the frequency of measurements and the specifics regarding the location of the stations the reader is referred to Sect. 2.3. Model data is not shown for months where there are no measurements available. For all of the organics shown in Fig. 6 no in-situ chemical production from the oxidation of larger organics occurs. Therefore the only atmospheric source is by direct emission from the surface. In terms of loss, the insoluble nature of most species means that wet deposition is also negligible resulting in chemical oxidation being the only loss term, although dilution via mixing occurs. Hence differences between the monthly mean mixing ratios 

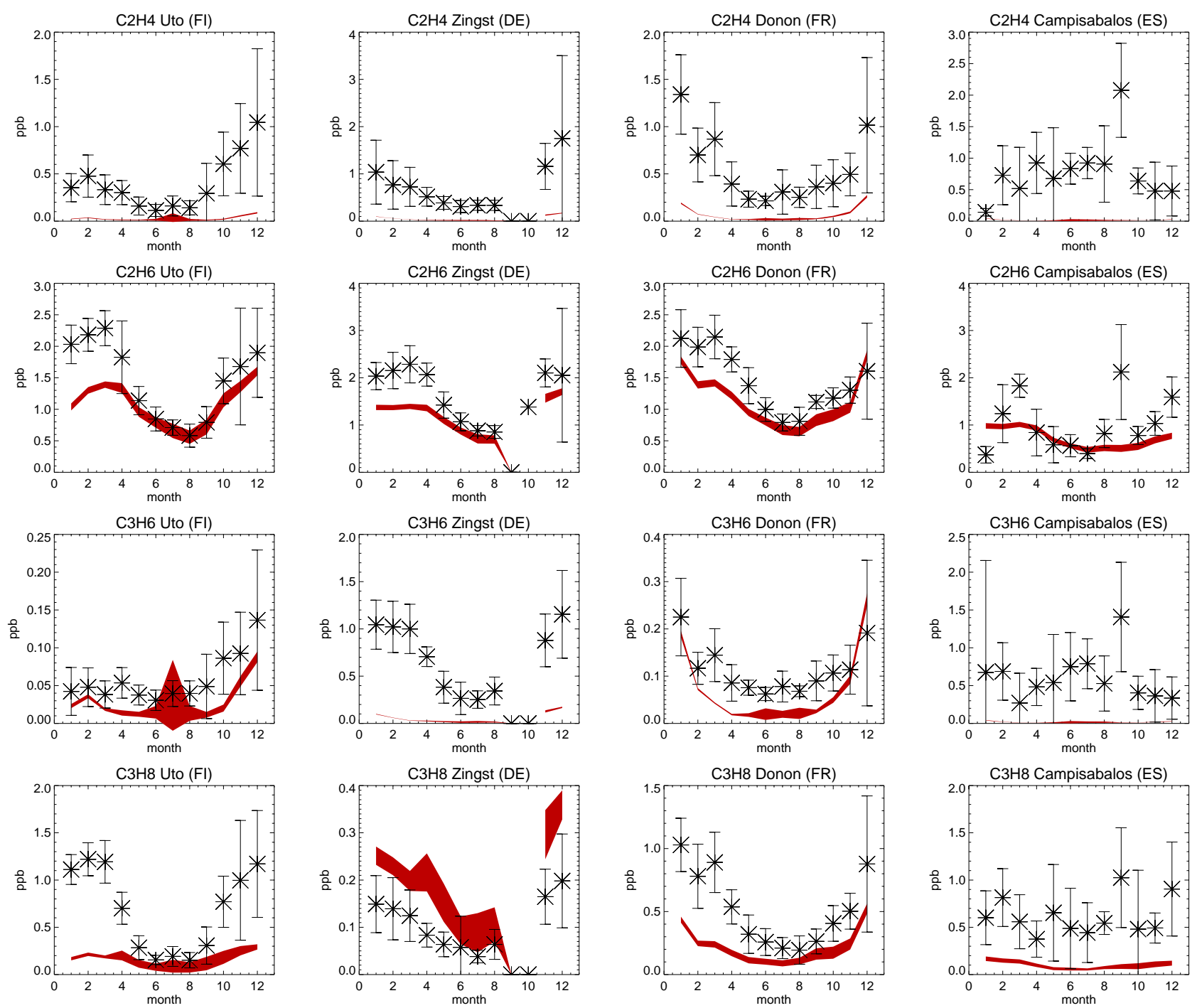

Fig. 6. The seasonal variability in selected $\mathrm{C} 2$ and $\mathrm{C} 3$ alkanes and alkenes sampled at various EMEP monitoring stations during 2000. Comparisons are shown for (from top row downwards) $\mathrm{C}_{2} \mathrm{H}_{4}, \mathrm{C}_{2} \mathrm{H}_{6}, \mathrm{C}_{3} \mathrm{H}_{6}$ and $\mathrm{C}_{3} \mathrm{H}_{8}$, respectively, for single stations located at Utö (Finland, $59.5^{\circ} \mathrm{N}, 21.1^{\circ} \mathrm{E}$ ), Zingst (Germany, 54.4 ${ }^{\circ} \mathrm{N}, 12.7^{\circ} \mathrm{E}$ ), Donon (France, $48.3^{\circ} \mathrm{N}, 7.8^{\circ} \mathrm{E}$ ) and Campisabalos $\left(\right.$ Spain, $41.1^{\circ} \mathrm{N}, 3.8^{\circ} \mathrm{W}$ ).

from the model and the observations are due to the either the chemical steady state and/or transport.

In Fig. 6 it can be clearly seen that there is a large difference in the ability that TM5 has towards capturing the observed seasonality in the resident molar mixing ratios between the various organic species shown. The variability in the observations can be significant during any particular month. Maximal concentrations and high variability occur during the winter months when biogenic emissions are low (e.g. at Donon). Therefore, most of the organic species exhibit a strong anti-correlation with the seasonality that is displayed in the biogenic emission inventories shown in Fig. 2, which is possibly related to the differences in their seasonal lifetimes considering the differences in the photo-chemical activity.
The atmospheric lifetime of $\mathrm{C}_{2} \mathrm{H}_{4}$ from the ensemble simulations is $1.9 \pm 0.2$ days, which is close to the range of 23 days given in the literature (Rudolph and Ehhalt, 1981; Jenkin and Clemitshaw, 2000). Although the anthropogenic emission source of $\mathrm{C}_{2} \mathrm{H}_{4}$ defined in the RETRO inventory decreases by $\sim 20 \%$ during the summer months in Europe (see Fig. 2b), these comparisons suggest there should be higher emission estimates or a more pronounced seasonal cycle in order for the model to be able to capture the relatively high mixing ratios during DJF. One possible cause of this under estimation is the additional NMHC emissions due to domestic heating during the winter at high northern latitudes, which is probably underestimated in the RETRO inventory. Given its short atmospheric lifetime, any increases in $\mathrm{C}_{2} \mathrm{H}_{4}$ must ideally occur at a regional scale. One exception is at 
Campisabalos in Spain, where there is no real seasonal cycle which is evident. This measurement site is located at an elevated altitude $(1.3 \mathrm{~km})$ on a plateau, meaning that it can be influenced by transport of polluted air from the FT. However, the large discrepancy between the ensemble mean and the observational monthly means, along with the constraints imposed by the relatively short atmospheric lifetime, suggests a significant local emission source which is missing from the inventories employed (as for the $\mathrm{C} 3$ analogue, see discussion below). The rural location of the site means that the variability in the seasonal anthropogenic emissions is likely to be rather low. Moreover, the low BB activity in the region does imply that the missing source term is not associated with wildfires. Differentiating as to whether the underestimate originates from the biogenic or anthropogenic emission component is not possible without performing associated trajectory calculations and additional sensitivity studies, which is beyond the focus of this study. Another potential cause of the under-predictions at both Utö and Zingst could also be missing shipping emissions. It should be noted that other studies concerned with capturing the correct global distribution of $\mathrm{C}_{2} \mathrm{H}_{4}$ in large scale atmospheric models have also found difficulties with regional representativity (e.g. Pozzer et al., 2007).

For $\mathrm{C}_{2} \mathrm{H}_{6}$ both the seasonal cycle and resident mixing ratios are captured rather well by TM5. This suggests that any seasonal differences concerning transport of more polluted air towards the measurement sites from urban centres located nearby is represented quite well using the ECMWF ERAInterim meteorology. For instance, at both Zingst and Donon the increase in mixing ratios during wintertime is reproduced providing confidence in the anthropogenic emission estimates of this species. Again, the exception is at Campisabalos in Spain, where significant under-predictions occur during the wintertime. Considering that the atmospheric lifetime of $\mathrm{C}_{2} \mathrm{H}_{6}$ is estimated to be between 1-3 months, thus comparable to that of CO, (Gupta et al., 1998; Jenkin and Clemitshaw, 2000) means that missing sources could occur large distances away from the measurement site. The atmospheric lifetime from the ensemble simulations is $75.6 \pm 3.9$ days, thus within the range published in the literature.

For the comparisons of the C3 organics shown in Fig. 6 there is a similar variability in the observations taken at the various measurement sites when compared to their $\mathrm{C} 2$ analogues. In general the tropospheric mixing ratios of $\mathrm{C}_{3} \mathrm{H}_{6}$ are quite low in TM5 throughout the European domain (between 20-100 ppt except at Donon during DJF). Comparing the magnitude and timing of the seasonal cycles shows that for sites where rather low monthly mixing ratios are observed the agreement is quite good, whereas for others the model significantly under predicts the resident mixing ratios (e.g. Campisabalos). No improvement occurs during summer indicating that the biogenic component is too low in all emission inventories considering that the atmospheric lifetime of $\mathrm{C}_{3} \mathrm{H}_{6}$ in the ensemble simulations is $\sim 0.5$ days, which is conversant with literature estimates (Jenkin and Clemitshaw, 2000). For $\mathrm{C}_{3} \mathrm{H}_{8}$ the tropospheric mixing ratios are between 0-300 ppt in TM5, which generally results in significant under predictions when compared to the observations. Again the exception is at Donon where resident mixing ratios in TM5 are of the order of $500 \mathrm{ppt}$ during winter time. The best agreement occurs during summertime suggesting that the biogenic flux estimates for $\mathrm{C}_{3} \mathrm{H}_{8}$ are of the right order of magnitude for the region. The global atmospheric lifetime of $\mathrm{C}_{3} \mathrm{H}_{8}$ in the ensemble simulations is $17.2 \pm 2.5$ days compared to $\sim 25$ days as given in the literature (Gupta et al., 1998), therefore relatively short. Following the same reasoning as for the $\mathrm{C}_{2}$ analogues, these comparisons suggest that the anthropogenic emission of $\mathrm{C}_{3} \mathrm{H}_{8}$ in the RETRO inventory is potentially too low during wintertime.

In terms of the uncertainty which is introduced by adopting the various emission estimates (shown as the 1- $\sigma$ deviation from the ensemble model mean), the influence is rather variable. For instance, the inability of the entire ensemble to capture accurate mixing ratios of $\mathrm{C}_{2} \mathrm{H}_{4}$ means that the estimated uncertainty is much too small. Thus in spite of the relatively large differences in the biogenic emission estimates shown in Fig. 2a ( $100 \%$ during summertime for Europe) the uncertainty in the concentrations remains rather low. For $\mathrm{C}_{2} \mathrm{H}_{6}$ the uncertainty in model mixing ratios is around $\sim 10 \%$ during the winter, increasing to $\sim 20 \%$ during JJA. For $\mathrm{C}_{3} \mathrm{H}_{6}$ the uncertainty in the model resident mixing ratios is quite variable across measurement sites, with a large uncertainty ( $>100 \%$ ) being introduced for JJA at Utö. For the other sites this decreases to around $\sim 50 \%$ although resident mixing ratios are within the ppt range. Finally, for $\mathrm{C}_{3} \mathrm{H}_{8}$ the uncertainty introduced is around $\sim 20-30 \%$ during the summer months, except at Zingst. In summary, the uncertainty introduced by varying emission methodologies into the regional distribution of these organic trace species ranges from $\sim 10-100 \%$ depending on the location.

\subsection{Isoprene}

Although our focus is primarily on C1-C3 BVOC species here we briefly focus on the uncertainty introduced for resident isoprene mixing ratios due to the differences in emission inventories for Europe. Figure 7 shows the corresponding plots for isoprene at a selected number of different EMEP measurement sites which represent a range of different scenarios. It should be noted that the measurements are taken during the day where the emission of isoprene exhibits a diurnal maximum (although this is also included in TM5). At northern latitudes and towards Eastern Europe the resident mixing ratios are of the order of 10-20 ppt, which is significantly lower than those simulated in TM5. In contrast, resident mixing ratios are an order of magnitude higher at the French measurement site, where the agreement with the model ensemble is quite good throughout the year. The most striking feature of the comparisons is the large uncertainty in 

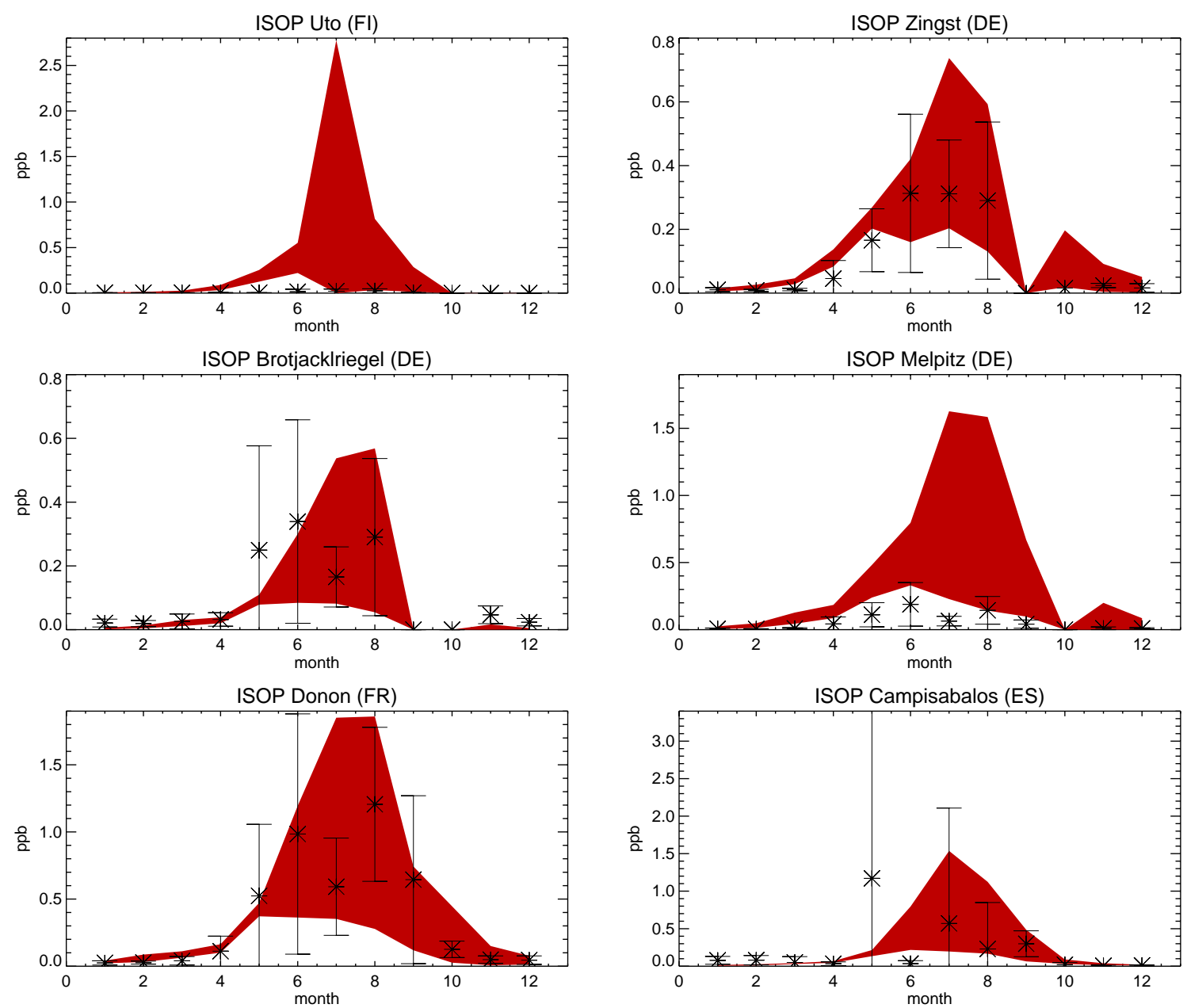

Fig. 7. The seasonal variability in isoprene across Europe as sampled at various EMEP monitoring stations during 2000. Comparisons are shown for single stations located at (from top to bottom) Utö (Finland, 59.5 ${ }^{\circ} \mathrm{N}, 21.1^{\circ} \mathrm{E}$ ), Zingst (Germany, $54.4^{\circ} \mathrm{N}, 12.7^{\circ} \mathrm{E}$ ), Brotjacklriegel $\left(\right.$ Germany, $48.5^{\circ} \mathrm{N}, 13.1^{\circ} \mathrm{E}$ ), Melpitz (Germany, $51.3^{\circ} \mathrm{N}, 12.5^{\circ} \mathrm{E}$ ), Donon (France, $48.3^{\circ} \mathrm{N}, 7.8^{\circ} \mathrm{E}$ ) and Campisabalos $\left(\right.$ Spain, $41.1^{\circ} \mathrm{N}$, $\left.3.8^{\circ} \mathrm{W}\right)$.

the resident mixing ratio of isoprene introduced by adopting the different emission inventories $(\sim 0.5-2.5 \mathrm{ppb}$ at all sites). In turn this introduces differences in both HCHO and $\mathrm{CO}$, the main oxidation products from isoprene (see next section). Although the model performance could potentially be improved using a finer horizontal resolution for the simulations, the largest discrepancies between the monthly mean mixing ratios shown in Fig. 7 exist for locations which are readily accessible (i.e. around the Baltic Sea near Finland) where constraints on isoprene emissions could be improved by using measurement data that is available in the literature (e.g. Jansen and De Serves, 1998; Lindfors and Laurila, 2000). Recently comparisons of European isoprene mixing ratios calculated online in a CTM with MEGAN against similar EMEP data for 2006 have also shown that there is a wide variability in agreement between different EMEP sites even when including yearly specific meteorological variabil- ity during the derivation of emission fluxes (Zare et al., 2012).

\subsection{Tropospheric CO}

Figure 8 shows the seasonal cycle in tropospheric $\mathrm{CO}$ as observed at 12 measurement sites in the GMD network, with the location of each measurement site being given in the figure caption. It can be seen that there is a strong seasonal cycle at both the $\mathrm{NH}$ and $\mathrm{SH}$ measurement stations, which is somewhat anti-correlated. Also shown are the 1- $\sigma$ variations from the ensemble model mean and the monthly mean values from the NOBVOC and NOISOPTERP simulations. In general, the seasonal cycle is captured rather well by the ensemble model mean, although under-predictions occur in the $\mathrm{NH}$ during the early part of the year (the so-called $\mathrm{NH}$ bias which occurs in many different large-scale global atmospheric chemistry models (Shindell et al., 2006)). The 

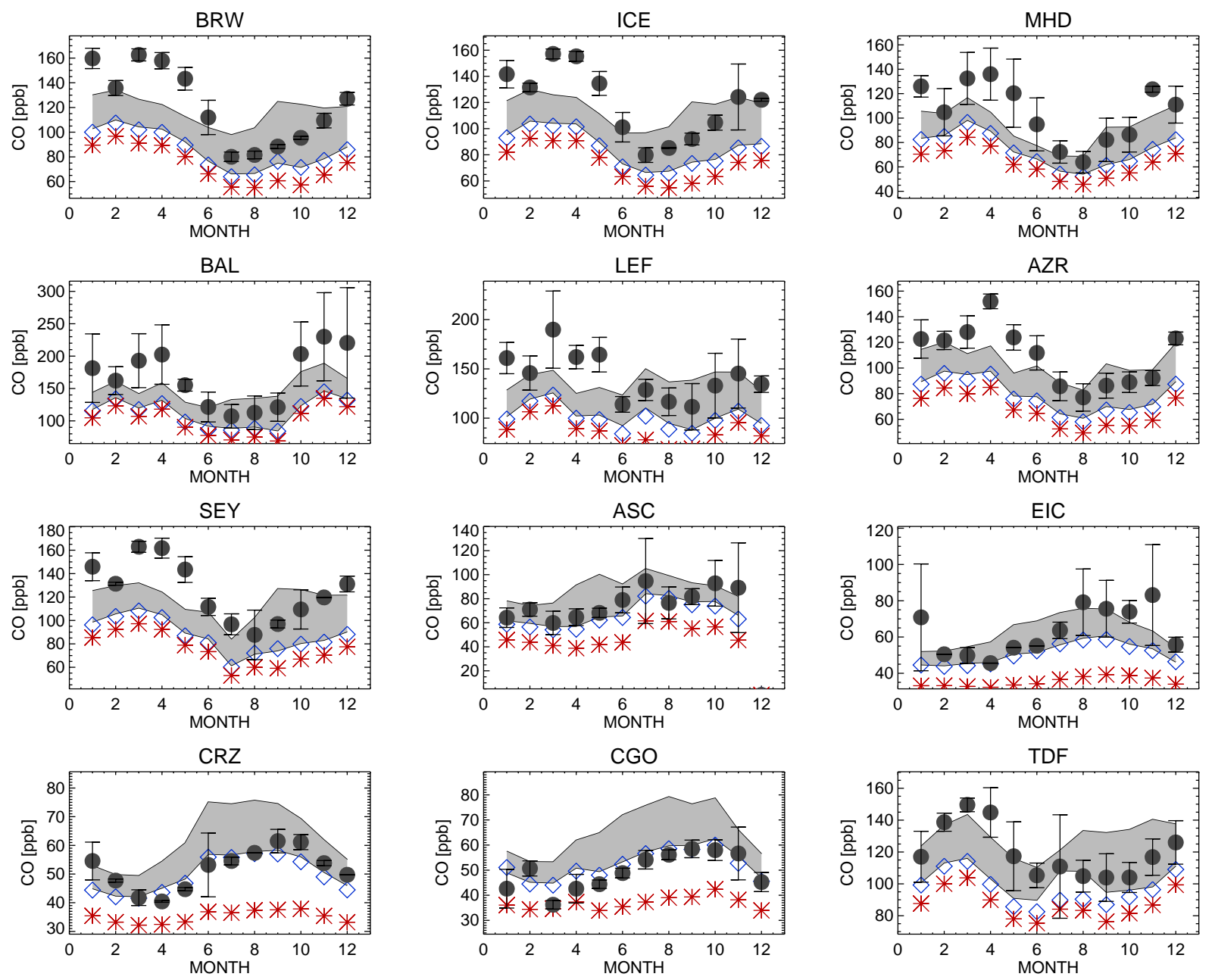

Fig. 8. Comparisons of monthly mean CO mixing ratios observed at various measurement sites from the GMD ground-based monitoring network (black filled circles and error bars), along with the 1- $\sigma$ variability in the ensemble mean (shaded grey band) and the corresponding monthly means from the NOBVOC (blue squares) and NOISOPTERP (red asterisks) simulations. The stations shown are (top left to bottom right) Barrow, Canada (BRW, 71.3 ${ }^{\circ} \mathrm{N}, 156.6^{\circ} \mathrm{W}$ ), Sorhofi, Iceland (ICE, 63.3 $\mathrm{N}, 20.3^{\circ} \mathrm{W}$ ), Mace Head, Ireland (MHD, 53.3 ${ }^{\circ} \mathrm{N}, 9.9^{\circ} \mathrm{W}$ ),

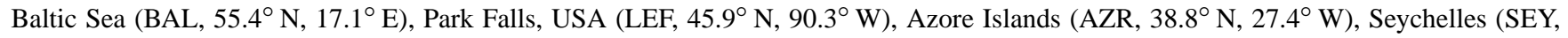
$4.7^{\circ} \mathrm{S}, 55.2^{\circ} \mathrm{E}$ ), Ascension Island (ASC, $7.9^{\circ} \mathrm{S}, 14.4^{\circ} \mathrm{W}$ ), Easter Island (EIC, $\left.27.2^{\circ} \mathrm{S}, 109.5^{\circ} \mathrm{W}\right)$, Crozet Island $\left(\mathrm{CRZ}, 46.5^{\circ} \mathrm{S}, 51.9^{\circ} \mathrm{E}\right)$, Cape Grim, Tasmania (CGO, $40.7^{\circ} \mathrm{S}, 144.7^{\circ} \mathrm{E}$ ) and Tierra Del Fuego, Argentina (TDF, 54.9 ${ }^{\circ} \mathrm{S}, 68.5^{\circ} \mathrm{W}$ ).

variability in the observed monthly mean is rather site dependent, but can be significantly larger than the corresponding variability in the ensemble model mean (e.g. MHD and LEF during spring). Comparing the monthly means shows that the emission of BVOC trace gases (excluding isoprene and the monoterpenes) contributes between $\sim 10-30 \%$ to tropospheric $\mathrm{CO}$ at the surface at global scale, whereas the cumulative contribution made by isoprene and the monoterpenes for many of the sites situated away from local isoprene emission sources is typically between $\sim 20-40 \%$ (e.g. ICE and BAL throughout the entire year). Therefore, the effect of $\mathrm{C} 1$ C3 BVOC species towards global CO mixing ratios in the remote environment is approximately the same order of magnitude. This holds for the majority of sites shown, although there are exceptions when measurement sites are either near or downwind of strong isoprene emission sources (e.g. EIC and CGO throughout the entire year). In terms of the uncertainty introduced towards the global distribution of $\mathrm{CO}$, biogenic emissions introduce around at least a $10-15 \%$ effect across all sites, becoming higher at some sites in the tropics and SH (e.g. EIC and CRZ). This shows that improving on the uncertainty in BVOC emission estimates is important for understanding and closing the global tropospheric $\mathrm{CO}$ budget. In turn, this has an effect on the oxidative capacity of the troposphere as we will discuss in Sect. 7.

To investigate the uncertainty introduced in the FT we show additional comparisons at selected high altitude measurement sites from the GMD network (above $2 \mathrm{~km}$ ) in 

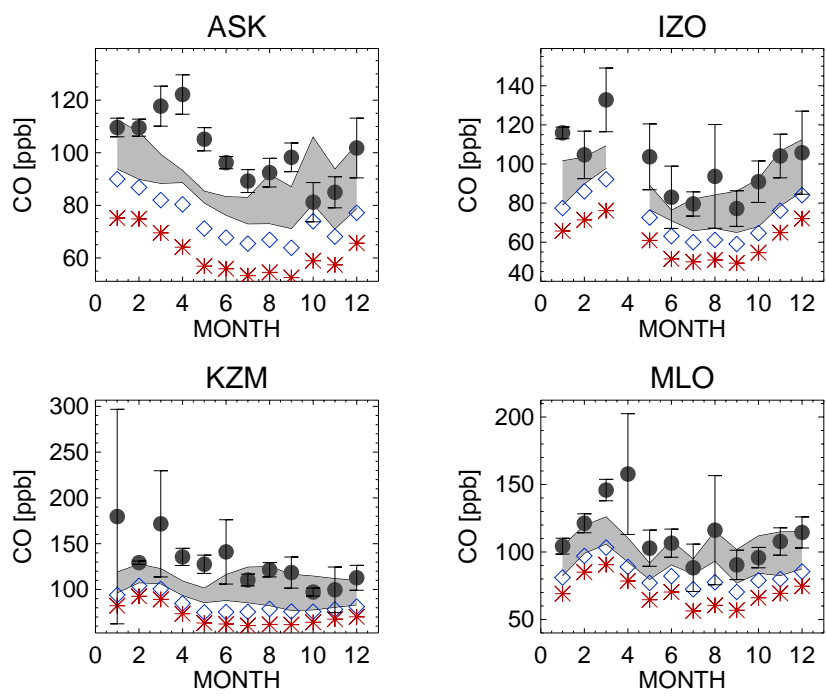

Fig. 9. Comparisons of monthly mean $\mathrm{CO}$ mixing ratios at various high altitude measurement sites from the GMD measurement network, along with the $1-\sigma$ variability in the ensemble mean (shaded grey area) and the corresponding monthly means from the NOBVOC (blue diamonds) and NOISOPTERP (red asterisks) simulations. The sites shown are Assekrem, Algeria (ASK, $23.2^{\circ} \mathrm{N}$, $5.4^{\circ} \mathrm{E} ; 2728 \mathrm{~m}$ ), Tenerife (IZO, $28.3^{\circ} \mathrm{N}, 16.5^{\circ} \mathrm{W} ; 2360 \mathrm{~m}$ ), Plateau Assy $\left(\mathrm{KZM}, 43.3^{\circ} \mathrm{N}, 77.9^{\circ} \mathrm{E} ; 2519 \mathrm{~m}\right)$ and Mauna Loa, Hawaii (MLO, $19.5^{\circ} \mathrm{N}, 155^{\circ} \mathrm{W} ; 3397 \mathrm{~m}$ ).

Fig. 9. For this purpose we show the corresponding monthly mean values in a similar format as those shown in Fig. 8. Again the model ensemble mean captures the observed seasonal cycle quite well throughout the year, except at ASK where an under prediction occurs during boreal spring. One potential source of this underestimation for ASK is that a small dry deposition velocity for $\mathrm{CO}$ is calculated in TM5 for this arid region using the approach of Ganzeveld and Lelieveld (1995), whereas measurements suggest no such loss process should occur in arid regions (Yonemura et al., 2000). For high altitude measurement sites which are surrounded by strong isoprene emission sources such as IZO based on Tenerife in the Canary Islands, the effect of C1$\mathrm{C} 3$ organics on resident $\mathrm{CO}$ mixing ratios is less than that of isoprene/monoterpenes. In that the ensemble mean does not exhibit the same variability as the measurements for certain months is likely related to regional "pulses" in local biogenic emissions related to variability in the local meteorology which is not captured using multi-year climatologies. However, the associated uncertainty in the model ensemble mean is approximately the same order of magnitude as that shown for the surface sites in the lower troposphere due to the atmospheric lifetime of $\mathrm{CO}$ being of the order of 1-2 months (see Sect. 7). This is quite different to that shown in Fig. 5 for tropospheric $\mathrm{O}_{3}$, where the maximum associated uncertainty is typically situated in the lower most troposphere.

\subsection{Uncertainty in the upper troposphere}

Finally we assess the importance of differences between the BVOC emission estimates on the composition of the UTLS by making comparisons against in-flight measurements made on passenger aircraft as part of the CARIBIC program. Figure 10 shows comparisons of the ensemble mean values (red line) for both $\mathrm{CO}$ and $\mathrm{O}_{3}$ against those observed for May, June, October and December. Also shown is the corresponding comparison for the NOBVOC simulation (blue dashed line). The 1- $\sigma$ deviation from the ensemble mean is indicated by the horizontally dashed area throughout. Measurements made during both the forward and the return flights are aggregated together and binned at a $2^{\circ}$ resolution with respect to either latitude or longitude. Given that the chemical time-step of TM5 is 15 min this results in a fairer comparison against the measurements, since variability at $1 \mathrm{~min}$ resolution cannot be captured by TM5. The flights are either to southern Africa (May, December) or the Maldives (June, October), with the flight paths being shown in Fig. 1.

From Fig. 10 it can be seen that the spatial gradients in both species are captured relatively well by TM5, except over Africa near the ITCZ where convective uplift is overestimated between $0-10^{\circ} \mathrm{N}$. The atmospheric lifetime of $\mathrm{CO}$ means it acts as a valid proxy for assessing convective uplift from the boundary layer, which seems to be too strong for this month over Africa. Air-masses uplifted from the boundary layer typically exhibit lower $\mathrm{O}_{3}$ mixing ratios than those observed at $\sim 250 \mathrm{hpa}$, resulting in a different signature for both species over convective regions. Comparing the NOBVOC simulation shows that $\mathrm{C} 1-\mathrm{C} 3 \mathrm{BVOC}$ emissions contribute to UTLS CO and $\mathrm{O}_{3}$ by $\sim 10 \%$ and $\sim 2 \%$, respectively. In terms of uncertainty the biggest impact is for $\mathrm{CO}$ in line with the findings for the high GMD measurement sites, where there is a $\sim 20 \%$ influence of the BVOC emission inventory used in TM5. For $\mathrm{O}_{3}$ the influence is more muted, where the flights which pass over the Indian Ocean (June, October) shows little uncertainty, although the observations are taken during one outward and one return flight meaning that the variability in the meteorology is likely to be small. This is in spite of the long range transport of air westwards during JJA by the monsoon circulation, meaning that differences in $\mathrm{UT} \mathrm{O}_{3}$ from the various biogenic estimates provided for India do not show up in the ensemble mean. The influence of biogenic $\mathrm{CH}_{4}$ emissions have recently been identified in later CARIBIC flights close to those to the Maldives presented here (Baker et al., 2012).

\section{Uncertainty in the seasonal distribution of $\mathrm{CO}$ and $\mathrm{O}_{3}$}

The uncertainty introduced into the global distribution of trace gas species in TM5 as a result of adopting different BVOC climatologies is quantified by analyzing the variability in the global distribution of the ensemble model mean. 

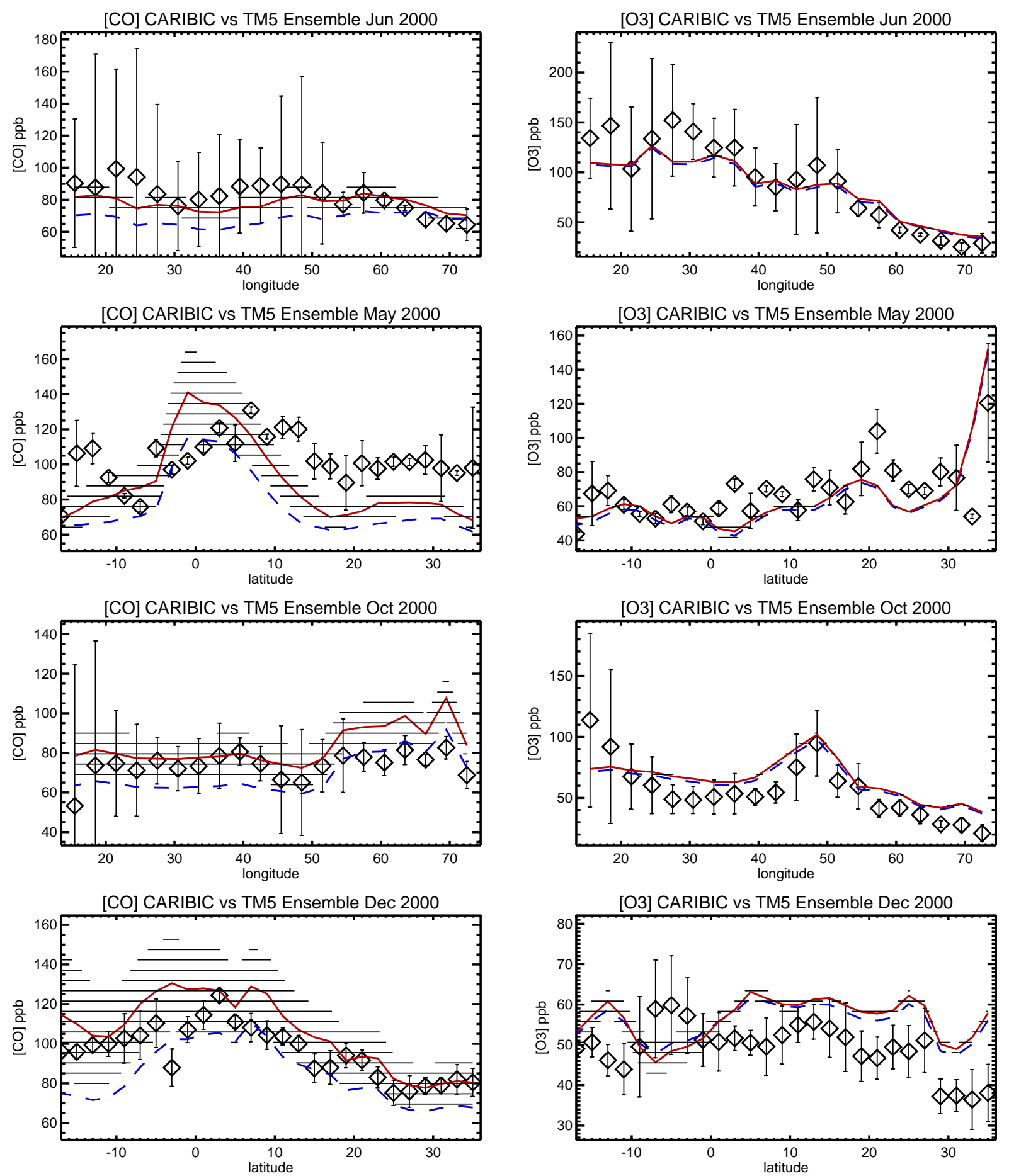

Fig. 10. Comparisons of CARIBIC in-situ flight data $(\diamond)$ with the TM5 model ensemble (red line), the NOBVOC simulation (dashed blue line) and 1- $\sigma$ spread in the model ensemble (hashed area). The months shown are May, June, October and December for the year 2000.

For this purpose we use the diagnostic which represents the absolute differences (in ppb) between the two extreme members of the model ensemble (namely ORCH and EMAC as defined by their total annual BVOC emission fluxes given in Table 2), hereafter referred to as the maximum Absolute Un- certainty (AU). We also define a Relative Uncertainty (RU), which is equal to the $\mathrm{AU}$ divided by the ensemble mean and provided as a ratio. The higher the value of the RU, the greater is the uncertainty introduced due to uncertainties in the BVOC emission estimates. A similar approach has 

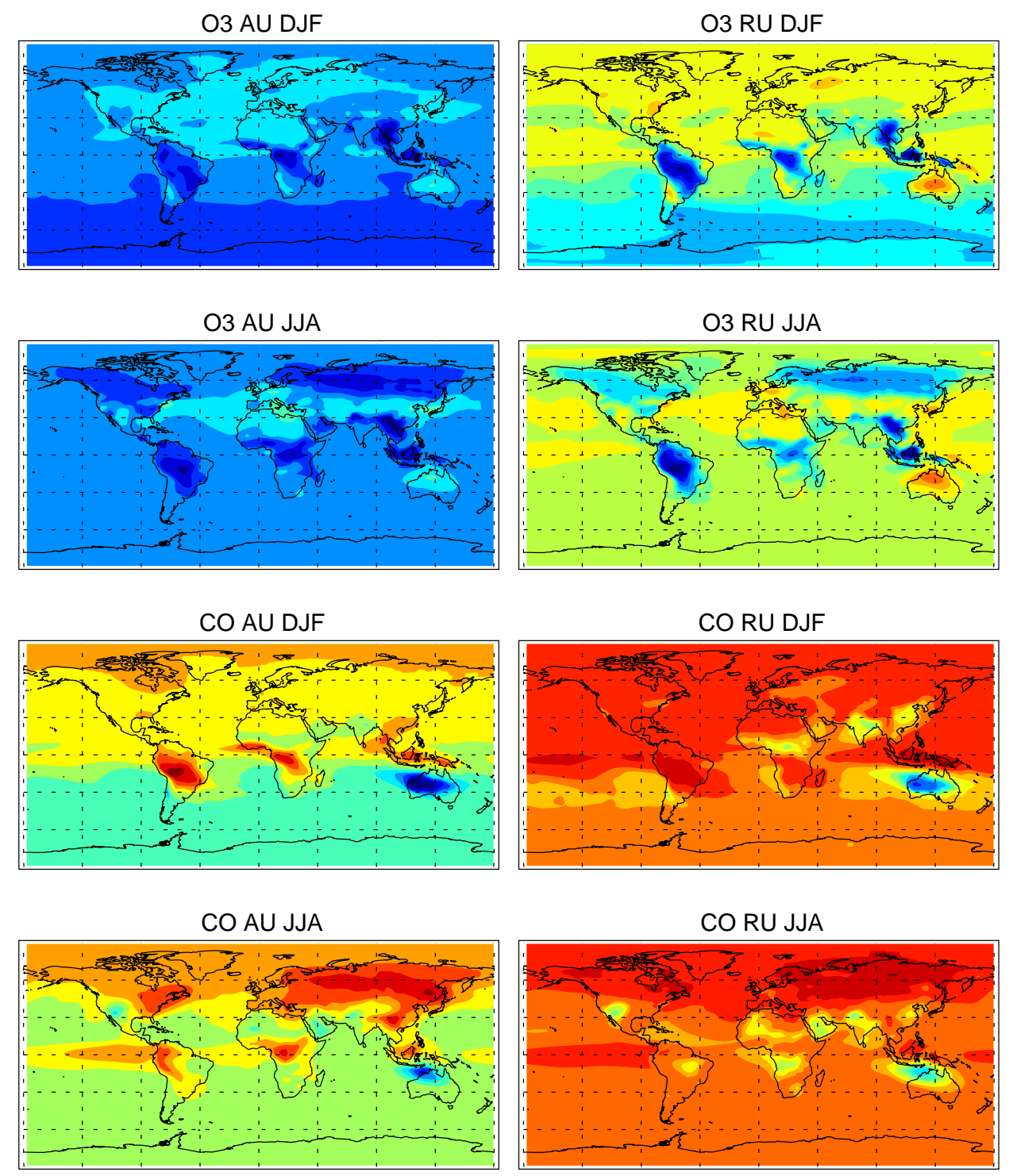

\section{$\mathrm{AU} \mathrm{ppb}$}
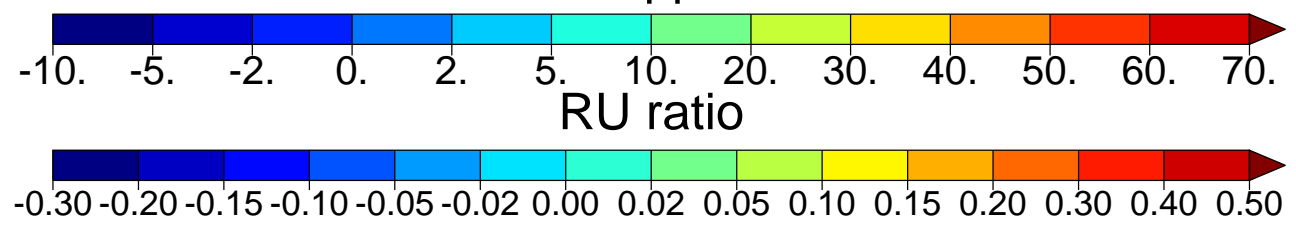

Fig. 11. The Absolute Uncertainty (AU) and Relative Uncertainty (RU) introduced by the variability in biogenic emission estimates for tropospheric $\mathrm{O}_{3}$ (top) and $\mathrm{CO}$ (bottom). Values are shown for seasons DJF and JJA.

been used in previous studies which investigated the uncertainty in the composition of the tropical troposphere introduced due to various anthropogenic emission estimates for future decades around equatorial Africa (Williams and van Velthoven, 2011).
Figure 11 shows the seasonal distribution of AU and RU values for $\mathrm{O}_{3}$ (top panels) and $\mathrm{CO}$ (bottom panels) when integrated from $\sim 750 \mathrm{hPa}$ to the surface for seasons DJF and JJA. It can be seen that the $\mathrm{AU}$ values equate to \pm 0 $10 \mathrm{ppb}$ for $\mathrm{O}_{3}$ and between 5-60 ppb for CO. Decreases of 0-2 ppb occur in the $\mathrm{SH}$ for $\mathrm{O}_{3}$ during DJF. The largest increases in $\mathrm{AU}$ values occur in the $\mathrm{NH}$ for $\mathrm{O}_{3}$ and near 

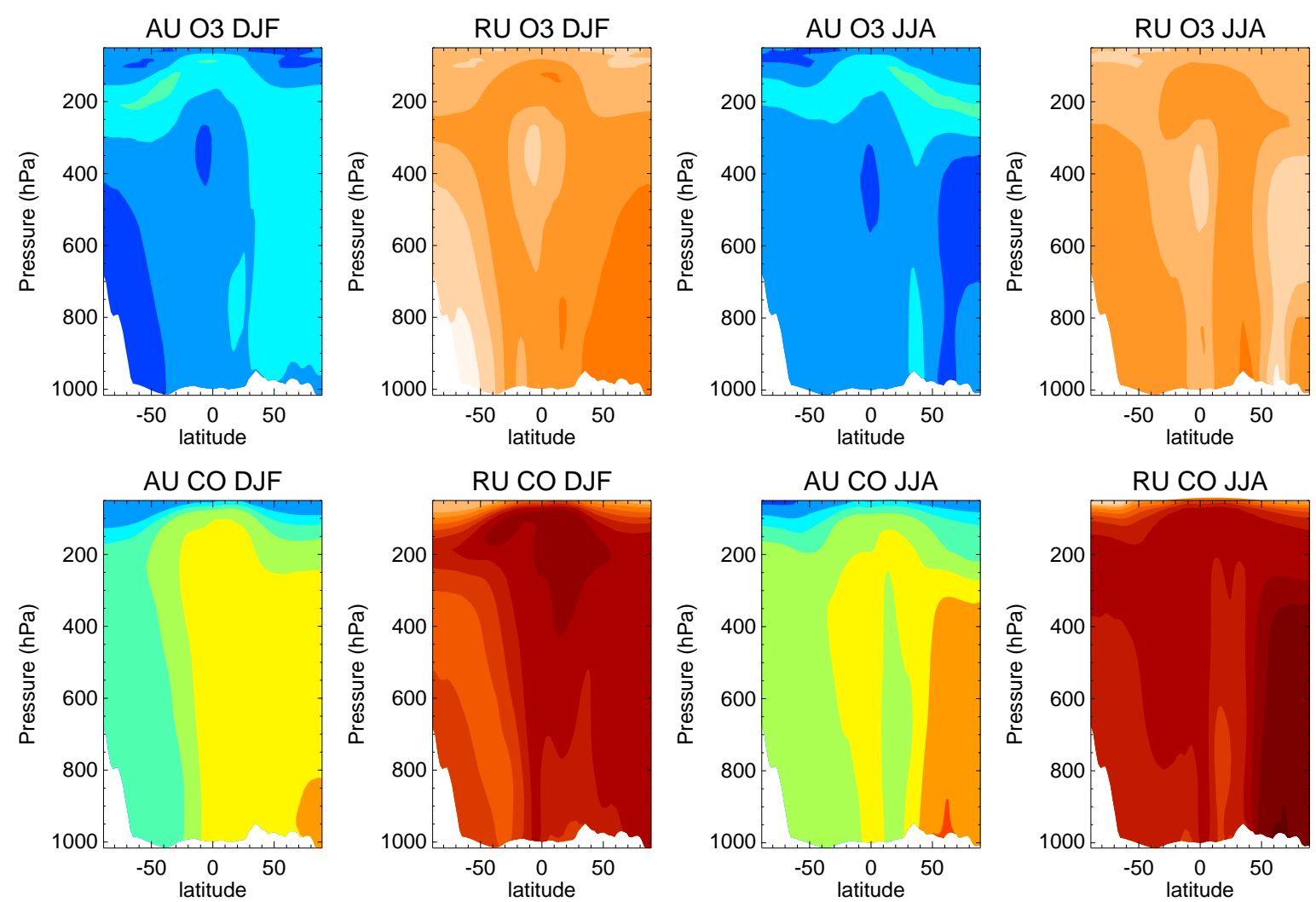

$\mathrm{AU} \mathrm{ppb}$

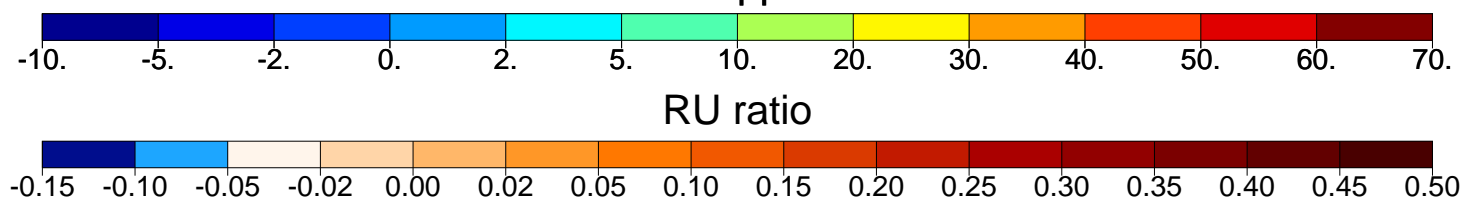

Fig. 12. The $\mathrm{AU}$ and $\mathrm{RU}$ introduced by the variability in biogenic emission estimates towards the Seasonal Zonal means for tropospheric $\mathrm{O}_{3}$ (top) and CO (bottom). Values are shown for seasons DJF and JJA.

the BVOC source regions for CO e.g. over the Amazon, Central Africa and South-East Asia. Above these regions there is an anti-correlation between the changes in the resident mixing ratios of both trace species most probably related to the significant differences in the isoprene emission fluxes between the ORCH and EMAC inventories. This results in increases in $\mathrm{CO}$ with simultaneous decreases in $\mathrm{O}_{3}$. A significant anti-correlation also occurs during both seasons around Indonesia and Australia, indicating a large variability in the BVOC emission estimates between the ORCH and EMAC inventories. Examining the corresponding RU values at global scale shows that this introduces an uncertainty of upto $\sim 15 \%$ in $\mathrm{LT} \mathrm{O}_{3}$ and between $\sim 20-50 \%$ in LT $\mathrm{CO}$ across wide regions. Therefore, the selection of BVOC emission inventory in global model simulations concerned with capturing the chemical composition of the troposphere throughout both hemispheres constitutes a dominant source of uncertainty.
Figure 12 shows the corresponding global zonal mean distribution in both the $\mathrm{AU}$ and $\mathrm{RU}$ values for both $\mathrm{O}_{3}$ and $\mathrm{CO}$ for seasons DJF and JJA. There are stark differences in the seasonal distribution of the $\mathrm{AU}$ values between trace species. For $\mathrm{O}_{3}$ the maximum $\mathrm{AU}$ values ( 5-10ppb) occur in the UT, whereas for $\mathrm{CO}(\sim 30-40 \mathrm{ppb})$ they either at high northern latitudes near the surface (DJF) or throughout the entire troposphere in the $\mathrm{NH}$ above $40^{\circ} \mathrm{N}$ (JJA). There is a seasonal signature in that the maximum $\mathrm{AU}$ values for $\mathrm{O}_{3}$ flips from the SH UT to the NH UT, with a larger AU $(\sim 2-$ $5 \mathrm{ppb}$ ) extending down to the surface during DJF. For CO the AU is larger during season JJA in both hemispheres, with a clear anti-correlation between the $\mathrm{AU}$ values for $\mathrm{O}_{3}$ and $\mathrm{CO}$ above $40^{\circ} \mathrm{N}$, when differences in NH biogenic $\mathrm{CO}$ emissions are greatest (c.f. Fig. 2). When analyzing the distribution in the $\mathrm{RU}$ values the range for $\mathrm{O}_{3}$ (between -0.02 and $0.1)$ is less extreme than that for CO $(0.1-0.45)$. The zonal means show that a larger uncertainty is introduced into the UT for $\mathrm{CO}$ than for $\mathrm{O}_{3}$ (in line with the conclusions of the 
Table 4. The annually integrated chemical budget terms for the in-situ production of tropospheric CO during 2000 for the four individual members of the model ensemble. The height of the troposphere is defined using the method defined in Stevenson et al. (2006). All burdens are given in $\mathrm{TgCO}_{\mathrm{yr}}{ }^{-1}$.

\begin{tabular}{lcccc}
\hline Diagnostic & ORCH & MEGAN & EMAC & POET \\
\hline CO burden & 376.7 & 331.0 & 291.0 & 367.1 \\
HCHO + hv & 1116.4 & 1042.0 & 946.4 & 1083.0 \\
OH + HCHO & 248.3 & 251.8 & 255.4 & 241.7 \\
$\mathrm{ALD}+\mathrm{hv}$ & 75.0 & 58.3 & 44.0 & 70.4 \\
$\mathrm{MGLY}+\mathrm{hv}$ & 57.1 & 53.6 & 41.4 & 58.4 \\
ISOP + O & 2.6 & 2.1 & 1.5 & 2.6 \\
ISPD & 64.9 & 60.4 & 44.5 & 65.6 \\
Terpenes & 9.0 & 6.3 & 6.7 & 9.0 \\
OH + CO & 2356.5 & 2210.6 & 2101.7 & 2323.0 \\
Dry deposition & 191.8 & 162.8 & 155.5 & 184.1 \\
CO tropospheric lifetime (days) & 54.1 & 51.0 & 47.2 & 53.6 \\
\hline
\end{tabular}

Table 5. Uncertainty in the global tropospheric burdens and atmospheric lifetimes of $\mathrm{O}_{3}, \mathrm{CO}$ and $\mathrm{CH}_{4}$ for the year 2000 as calculated using the model ensemble. The burdens are given in $\mathrm{Tg}$ species. The uncertainty is calculated using the $1-\sigma$ deviation in the ensemble mean divided by the ensemble mean, where it is given as a percentage. For $\mathrm{CH}_{4}$ we assume a fixed soil sink of $30 \mathrm{Tg} \mathrm{yr}^{-1}$. The troposphere is defined using the method defined in Stevenson et al. (2006). All burdens are given in Tg species.

\begin{tabular}{lcc}
\hline Diagnostic & $\begin{array}{c}\text { Ensemble } \\
\text { mean }\end{array}$ & $\begin{array}{c}\text { Uncertainty } \\
(\%)\end{array}$ \\
\hline $\mathrm{BCO}$ & 341.5 & 11.4 \\
$\mathrm{BO}_{3}$ & 313.1 & 1.0 \\
$\mathrm{BCH}_{4}$ & 4861.0 & 0.03 \\
$\mathrm{CO}$ tropospheric lifetime (days) & 51.5 & 6.1 \\
$\mathrm{O}_{3}$ tropospheric lifetime (days) & 24.03 & 0.2 \\
$\mathrm{CH}_{4}$ atmospheric lifetime (years) & 8.94 & 3.3 \\
\hline
\end{tabular}

CARIBIC comparison shown in Sect. 5.5). Considering the tropospheric distribution of $\mathrm{O}_{3}$, the highest relative uncertainty is introduced in the NH LT during DJF.

In Table 4 we present the annual budget terms related to the in-situ production of $\mathrm{CO}$ to investigate why such a large impact is introduced in the global distribution of $\mathrm{CO}$ throughout the model ensemble. Comparing the tropospheric burden of $\mathrm{CO}$ shows that it varies by $\sim 80 \mathrm{Tg}$ between the different simulations, which equates to $\sim 11 \%$ of the ensemble BCO (see next section). A major factor is the variability in the biogenic $\mathrm{CO}$ emission estimates between inventories (see Table 2) which equates to $\sim 100 \mathrm{Tg} \mathrm{CO} \mathrm{yr}^{-1}$ across inventories. For the in-situ component the largest perturbation in the chemical production of $\mathrm{CO}$ is due to the variability in $\mathrm{HCHO}$ oxidation, which accounts for more than $70 \%$ of the integrated in-situ production. Analysing the chemical budget terms for HCHO production by the modified CB05 chemical mechanism (not shown) reveals that, in turn,
HCHO mixing ratios are mainly affected by the oxidation of isoprene $(\sim 7.9 \%)$, ISPD $(\sim 9.1 \%), \mathrm{CH}_{3} \mathrm{OH}(\sim 4.2 \%)$, $\mathrm{CH}_{3} \mathrm{OOH}(\sim 20.3 \%)$ and oxidation of peroxy radicals by NO $(\sim 46.7 \%)$. From Table 4 it can be seen that the variability in this production term for the members of the ensemble is larger than the variability in the direct emissions, equating to more than $150 \mathrm{Tg} \mathrm{CO} \mathrm{yr}^{-1}$ across simulations. For tropospheric $\mathrm{CO}$, the other important terms include oxidation of lumped higher aldehydes and MGLY. The variability introduced directly from isoprene and monoterpene oxidation is rather low compared to these other terms as determined by the stoichiometry of the modified CB05 mechanism. One important difference between the two major terms which affect the global distribution of the RU is that those due to the emission term are limited to the $\mathrm{NH}$ whereas the variability in the in-situ production term occurs throughout the troposphere in both hemispheres.

\section{Uncertainty in global oxidative capacity and atmospheric lifetimes}

Finally in this section we examine the influence of BVOC emission estimates on global oxidative capacity and atmospheric lifetimes. In general the atmospheric lifetime of any trace gas species is determined by the global burden divided by the cumulative loss by both dry and wet deposition and photo-chemical oxidation. In Sect. 6 we have shown that a large uncertainty in the distribution of tropospheric $\mathrm{CO}$ exists due to uncertainties in BVOC emission estimates. Given that the oxidation of $\mathrm{CO}$ by $\mathrm{OH}$ accounts for $\sim 35 \%$ of the total annual loss of $\mathrm{OH}$ in the troposphere means that any uncertainty in global mixing ratios of $\mathrm{CO}$ will influence the lifetime of other long-lived gases such as $\mathrm{CH}_{4}$, especially considering a major fraction of the oxidation occurs in the tropics which also exhibits high biogenic emissions. Therefore, examining the variability in $\tau_{\mathrm{CH}_{4}}$ provides a useful diagnostic 
for assessing the perturbations in oxidative capacity in the ensemble model mean and the consequences for the associated uncertainty related to such diagnostics.

Table 5 presents the ensemble model mean values of $\mathrm{BCO}$, $\mathrm{BO}_{3}$ and $\mathrm{BCH}_{4}$ and their associated lifetimes. For each of the values we provide an assessment of the uncertainty introduced by dividing the 1- $\sigma$ deviation of the mean by the ensemble mean. In agreement with Figs. 11 and 12 we find that the uncertainty in $\mathrm{BCO}$ is an order of magnitude larger than for the $\mathrm{BO}_{3}$. Therefore, although there can be appreciable regional differences in $\mathrm{AU}$ as shown in Fig. 11, the uncertainty in the $\mathrm{BO}_{3}$ is rather muted when considering other potential sources of uncertainty such as the influence of seasonal variability in dry deposition fluxes and uncertainties in global $\mathrm{NO}_{\mathrm{x}}$ emissions. For $\mathrm{CH}_{4}$ the uncertainty in the total atmospheric burden is small, although the total atmospheric burden is much larger than for the other trace species which results in a smaller relative impact. Examining the uncertainty introduced into the associated atmospheric lifetimes shows that there is a $\sim 6 \%$ uncertainty in $\tau \mathrm{CO}$ (equating to $\sim 3$ days) and, more importantly when considering its warming potential, a $\sim 3.3 \%$ uncertainty on $\tau \mathrm{CH}_{4}$ (equating to $\sim 108$ days). This is larger than the uncertainty on $\tau \mathrm{CH}_{4}$ introduced by the variability across $\mathrm{BB}$ emission inventories, which have been shown to be less than 1\% (Williams et al., 2012b). However, it should be noted that if the biogenic emission of $\mathrm{CO}$ and soil $\mathrm{NO}_{\mathrm{x}}$ are correlated due to their sources being dependent on e.g. precipitation intensity then the significant uncertainty calculated in this study could become more muted if there would be corresponding changes in biogenic $\mathrm{NO}_{\mathrm{x}}$ (and thus $\mathrm{O}_{3}$ ). This finding also shows that inter-annual variability in biogenic fluxes could be a contributing factor to the observed variability in the $\mathrm{CH}_{4}$ growth rate (e.g. Dlugokencky et al., 2011), especially when utilising global models for the interpretation of potential causes.

\section{Conclusions}

In this study we have quantified the uncertainty introduced into large-scale chemical simulations of the troposphere by the variability which exists between different emission estimates for Biogenic Volatile Organic Compounds (BVOC) as provided in a suite of climatologies using the 3-D global chemistry-transport model TM5. For this purpose we have implemented the recently developed modified CB05 chemical mechanism, which includes an explicit description of the oxidation of $\mathrm{C} 1$ to $\mathrm{C} 3$ organic trace species. By examining the different BVOC emission estimates for a number of predefined regions we have shown that biogenic sources are the dominant terms for organic trace species such as ethene and acetone when integrating annually and seasonally. By performing sensitivity studies we have shown that the influence of biogenic $\mathrm{C} 1$ to $\mathrm{C} 3$ emissions has an appreciable effect on the global resident mixing ratios of tropospheric $\mathrm{O}_{3}$ and $\mathrm{CO}$ of $\sim 2.5 \%$ and $\sim 10.8 \%$, respectively. This equates to approximately a third of the influence due to isoprene and the monoterpenes.

By analysing an ensemble of 3-D global chemistrytransport model simulations for the year 2000, each adopting a different estimate for biogenic emissions, we have shown that the impact on the global distribution of $\mathrm{CO}$ is significantly more important than that for tropospheric $\mathrm{O}_{3}$ as a result of both variability in the global emission estimates and perturbations in the in-situ photochemical production of $\mathrm{CO}$ from other organic trace precursors, most notably formaldehyde. Comparing the model output against a variety of different observational datasets at global scale and examining a set of diagnostics developed to represent uncertainty, we have shown that the largest uncertainty for tropospheric $\mathrm{O}_{3}$ occurs in the lower troposphere (between -2 to $10 \%$ ), whereas that for tropospheric $\mathrm{CO}$ extends up to the upper troposphere (typically between 10 to $45 \%$ ). We also show that the modified CB05 mechanism captures both the seasonal cycles and latitudinal variability of both trace species quite well, providing confidence in our simulations. Although the scarcity of measurement sites places limits on the extent of model validation which can be performed for the year 2000, we have shown that comparisons made for the $\mathrm{C} 2$ and $\mathrm{C} 3$ alkanes and alkenes indicate that the cumulative emission estimates for the alkenes appear to be too low in the European domain, where there is an uncertainty of between $\sim 10-20 \%$ in the resident mixing ratios due to the $\mathrm{BVOC}$ emission inventories. For isoprene there is a significant over-prediction for the high northern latitudes, whereas for the rest of Europe the agreement is more favourable although there is a significant uncertainty of $\sim 100 \%$ in the resident mixing ratios between biogenic inventories.

Finally, in terms of global burdens and oxidative capacity, the uncertainty in the global burden of $\mathrm{CO}$ of $\sim 11 \%$ introduced by biogenic BVOC emission estimates results in an associated uncertainty in the tropospheric lifetime of $\mathrm{CO}$ of $\sim 6 \%$ and the atmospheric lifetime of $\mathrm{CH}_{4}$ of $\sim 3.3 \%$, which is considerable. For tropospheric $\mathrm{O}_{3}$ the uncertainty in global burden and lifetime is rather small under conditions of fixed $\mathrm{NO}_{\mathrm{x}}$ emissions. The uncertainty in the atmospheric lifetime of $\mathrm{CH}_{4}$ is larger than that found across different biomass burning emission estimates and could contribute to the observed variability in the global grow rates of $\mathrm{CH}_{4}$ over the last decades. 
Table A1. A comprehensive description of the modified CB05 chemical mechanism. The reaction products $\mathrm{O}_{2}$ and $\mathrm{H}_{2} \mathrm{O}$ are not shown. The sources of the reaction stoichiometry and chemical reaction data is thus: [1] Yarwood et al. (2005), [2] Sander et al. (2011), [3] IUPAC datasheet (www.iupac-kinetic.ch.cam.ac.uk), [4] Archibald et al. (2010), [5] Zaveri and Peters, (1999), [6] Atkinson et al. (2006), [7] Products modified in this study, [8] Houweling et al. (1998), [9] Horowitz et al. (2003), [10] Atkinson et al. (2004).

\begin{tabular}{|c|c|c|c|}
\hline Reactants & Products & Rate expression & Reference \\
\hline $\mathrm{NO}+\mathrm{O}_{3}$ & $\mathrm{NO}_{2}$ & $3.0 \times 10^{-12} * \exp (-1500 / \mathrm{T})$ & [1] \\
\hline $\mathrm{NO}+\mathrm{HO}_{2}$ & $\mathrm{NO}_{2}+\mathrm{OH}$ & $3.5 \times 10^{-12} * \exp (250 / \mathrm{T})$ & [1] \\
\hline $\mathrm{NO}+\mathrm{CH}_{3} \mathrm{O}_{2}$ & $\mathrm{HCHO}+\mathrm{HO}_{2}+\mathrm{NO}_{2}$ & $2.8 \times 10^{-12} * \exp (300 / \mathrm{T})$ & [1] \\
\hline $\mathrm{NO}_{2}+\mathrm{OH}(+\mathrm{M})$ & $\mathrm{HNO}_{3}$ & $\begin{array}{l}\mathrm{K}_{0}=1.8 \times 10^{-30} *(300 / \mathrm{T})^{3.0} \\
\mathrm{~K}_{\infty}=2.8 \times 10^{-11}\end{array}$ & {$[1],[2]$} \\
\hline $\mathrm{OH}+\mathrm{HNO}_{3}$ & $\mathrm{NO}_{3}$ & $\begin{array}{l}\mathrm{K}_{0}=2.41 \times 10^{-14} * \exp (460 / \mathrm{T}) \\
\mathrm{K}_{2}=2.29 \times 10^{-17} *(2199 / \mathrm{T}) \\
\mathrm{K}_{3}=6.51 \times 10^{-14} *(1335 / \mathrm{T})\end{array}$ & {$[1],[2]$} \\
\hline $\mathrm{NO}_{2}+\mathrm{O}_{3}$ & $\mathrm{NO}_{3}$ & $1.2 \times 10^{-13} * \exp (-2540 / \mathrm{T})$ & [1] \\
\hline $\mathrm{NO}+\mathrm{NO}_{3}$ & $\mathrm{NO}_{2}+\mathrm{NO}_{2}$ & $1.5 \times 10^{-11} * \exp (170 / \mathrm{T})$ & [1] \\
\hline $\mathrm{NO}_{2}+\mathrm{NO}_{3}$ & $\mathrm{~N}_{2} \mathrm{O}_{5}$ & $\begin{array}{l}\mathrm{K}_{0}=2.0 \times 10^{-30} * \exp (300 / \mathrm{T})^{4.4} \\
\mathrm{~K}_{\infty}=1.4 \times 10^{-12} *(300 / \mathrm{T})^{0.7}\end{array}$ & {$[1],[2]$} \\
\hline $\mathrm{N}_{2} \mathrm{O}_{5}$ & $\mathrm{NO}_{2}+\mathrm{NO}_{3}$ & $2.7 \times 10^{-27} * \exp (11000 / \mathrm{T})$ & {$[1],[2]$} \\
\hline $\mathrm{NO}_{2}+\mathrm{HO}_{2}$ & $\mathrm{HNO}_{4}$ & $\begin{array}{l}\mathrm{K}_{0}=2.0 \times 10^{-31} *(300 / \mathrm{T})^{3.4} \\
\mathrm{~K}_{\infty}=2.9 \times 10^{-12} *(300 / \mathrm{T})^{1.1}\end{array}$ & {$[1],[2]$} \\
\hline $\mathrm{HNO}_{4}(+\mathrm{M})$ & $\mathrm{NO}_{2}+\mathrm{HO}_{2}$ & $2.1 \times 10^{-27 *} \exp (10900 / \mathrm{T})$ & {$[1],[2]$} \\
\hline $\mathrm{OH}+\mathrm{HNO}_{4}$ & $\mathrm{NO}_{2}$ & $1.3 \times 10^{-12} * \exp (380 / \mathrm{T})$ & {$[1],[2]$} \\
\hline $\mathrm{NO}_{3}+\mathrm{HO}_{2}$ & $\mathrm{HNO}_{3}$ & $4.0 \times 10^{-12}$ & {$[1],[3]$} \\
\hline $\mathrm{O}\left({ }^{1} \mathrm{D}\right)(+\mathrm{M})$ & & $\begin{array}{l}3.3 \times 10^{-11} * \exp (55 / \mathrm{T}) *\left[\mathrm{O}_{2}\right]+ \\
2.5 \times 10^{-11} * \exp (110 / \mathrm{T}) *\left[\mathrm{~N}_{2}\right]\end{array}$ & {$[1],[2]$} \\
\hline $\mathrm{O}\left({ }^{1} \mathrm{D}\right)+\mathrm{H}_{2} \mathrm{O}$ & $\mathrm{OH}+\mathrm{OH}$ & $1.63 \times 10^{-10} * \exp (60 / \mathrm{T})$ & {$[1],[2]$} \\
\hline $\mathrm{O}_{3}+\mathrm{HO}_{2}$ & $\mathrm{OH}$ & $1.0 \times 10^{-14} * \exp (-490 / \mathrm{T})$ & [1] \\
\hline $\mathrm{CO}+\mathrm{OH}$ & $\mathrm{HO}_{2}$ & $\begin{array}{l}\mathrm{K}_{0}=5.9 \times 10^{-33} *(300 / \mathrm{T})^{1.4} \\
\mathrm{~K}_{\infty}=1.1 \times 10^{-12} *(300 / \mathrm{T})^{-1.3} \\
\mathrm{~K}_{0}=1.5 \times 10^{-13} *(300 / \mathrm{T})^{-0.6} \\
\mathrm{~K}_{\infty}=2.9 \times 10^{9} *(300 / \mathrm{T})^{-6.1}\end{array}$ & {$[1],[2]$} \\
\hline $\mathrm{O}_{3}+\mathrm{OH}$ & $\mathrm{HO}_{2}$ & $1.7 \times 10^{-12} * \exp (-940 / \mathrm{T})$ & [1] \\
\hline $\mathrm{OH}+\mathrm{H}_{2} \mathrm{O}_{2}$ & $\mathrm{HO}_{2}$ & $1.8 \times 10^{-12}$ & {$[1],[2]$} \\
\hline $\mathrm{OH}+\mathrm{HCHO}$ & $\mathrm{CO}+\mathrm{HO}_{2}$ & $5.5 \times 10^{-12} * \exp (125 / \mathrm{T})$ & {$[1],[2]$} \\
\hline $\mathrm{OH}+\mathrm{CH}_{4}$ & $\mathrm{CH}_{3} \mathrm{O}_{2}$ & $2.45 \times 10^{-12} * \exp (-1775 / \mathrm{T})$ & [1] \\
\hline $\mathrm{OH}+\mathrm{CH}_{3} \mathrm{OOH}$ & $0.7 \mathrm{CH}_{3} \mathrm{O}_{2}+0.3 \mathrm{HCHO}+0.3 \mathrm{OH}$ & $3.8 \times 10^{-12} * \exp (200 / \mathrm{T})$ & {$[1]$} \\
\hline $\mathrm{OH}+\mathrm{CH}_{3} \mathrm{OH}$ & $\mathrm{HCHO}+\mathrm{HO}_{2}$ & $2.85 \times 10^{-12} * \exp (-345 / \mathrm{T})$ & {$[1],[3]$} \\
\hline $\mathrm{OH}+\mathrm{HCOOH}$ & $\mathrm{HO}_{2}$ & $4.0 \times 10^{-13}$ & [1] \\
\hline $\mathrm{OH}+\mathrm{ROOH}$ & $\begin{array}{l}0.77 \mathrm{XO}_{2}+0.04 \mathrm{ALD} 2+0.19 \\
\mathrm{CH}_{3} \mathrm{COCHO}+0.23 \mathrm{OH}+\mathrm{RXPAR}\end{array}$ & $2.0 \times 10^{-11}$ & {$[4],[5]$} \\
\hline $\mathrm{CH}_{3} \mathrm{O}_{2}+\mathrm{HO}_{2}$ & $\mathrm{CH}_{3} \mathrm{OOH}$ & $4.1 \times 10^{-13} * \exp (750 / \mathrm{T})$ & [1] \\
\hline $\mathrm{CH}_{3} \mathrm{O}_{2}+\mathrm{CH}_{3} \mathrm{O}_{2}$ & $\begin{array}{l}0.66 \mathrm{HCHO}+0.32 \mathrm{HO}_{2}+0.34 \\
\mathrm{CH}_{3} \mathrm{OH}\end{array}$ & $9.5 \times 10^{-14} * \exp (390 / \mathrm{T})$ & {$[2],[5]$} \\
\hline $\mathrm{NO}_{3}+\mathrm{CH}_{3} \mathrm{O}_{2}$ & $\mathrm{NO}_{2}+\mathrm{HO}_{2}+\mathrm{HCHO}$ & $1.2 \times 10^{-12}$ & {$[3],[5]$} \\
\hline $\mathrm{OH}+\mathrm{HO}_{2}$ & & $4.8 \times 10^{-11} * \exp (250 / \mathrm{T})$ & {$[1]$} \\
\hline $\mathrm{HO}_{2}+\mathrm{HO}_{2}$ & $\mathrm{H}_{2} \mathrm{O}_{2}$ & $\begin{array}{l}3.5 \times 10^{-13} * \exp (430 / \mathrm{T}) \\
1.77 \times 10^{-33} * \exp (1000 / \mathrm{T}) \\
1.4 \times 10^{-21} * \exp (2200 / \mathrm{T})\end{array}$ & {$[1],[2]$} \\
\hline $\mathrm{OH}+\mathrm{H}_{2}$ & $\mathrm{HO}_{2}$ & $2.8 \times 10^{-12} * \exp (-1800 / \mathrm{T})$ & [1] \\
\hline $\mathrm{NO}_{3}+\mathrm{HCHO}$ & $\mathrm{HNO}_{3}+\mathrm{CO}+\mathrm{HO}_{2}$ & $5.8 \times 10^{-16}$ & {$[1]$} \\
\hline $\mathrm{ALD} 2+\mathrm{OH}$ & $\mathrm{C}_{2} \mathrm{O}_{3}$ & $\begin{array}{l}\text { Average of: } \\
4.4 \times 10^{-12} * \exp (365 / \mathrm{T}) \\
5.1 \times 10^{-12} * \exp (405 / \mathrm{T})\end{array}$ & {$[1],[6]$} \\
\hline $\mathrm{ALD} 2+\mathrm{NO}_{3}$ & $\mathrm{HNO}_{3}+\mathrm{C}_{2} \mathrm{O}_{3}$ & $\begin{array}{l}\text { Average of: } \\
1.4 \times 10^{-12} * \exp (-1860 . / \mathrm{T}) \\
6.4 \times 10^{-15}\end{array}$ & {$[1],[6]$} \\
\hline
\end{tabular}


Table A1. Continued.

\begin{tabular}{|c|c|c|c|}
\hline Reactants & Products & Rate expression & Reference \\
\hline $\mathrm{NO}+\mathrm{O}_{3}$ & $\mathrm{NO}_{2}$ & $3.0 \times 10^{-12} * \exp (-1500 / \mathrm{T})$ & [1] \\
\hline $\mathrm{NO}+\mathrm{C}_{2} \mathrm{O}_{3}$ & $\mathrm{NO}_{2}+\mathrm{CH}_{3} \mathrm{O}_{2}$ & $8.1 \times 10^{-12} * \exp (270 / \mathrm{T})$ & {$[1]$} \\
\hline $\mathrm{NO}_{2}+\mathrm{C}_{2} \mathrm{O}_{3}$ & PAN & $\begin{array}{l}\mathrm{K}_{0}=2.7 \times 10^{-28} *(300 / \mathrm{T})^{7.1} \\
\mathrm{~K}_{\infty}=1.2 \times 10^{-11} *(300 / \mathrm{T})^{0.9}\end{array}$ & {$[1],[6]$} \\
\hline PAN & $\mathrm{NO}_{2}+\mathrm{C}_{2} \mathrm{O}_{3}$ & $\begin{array}{l}\mathrm{K}_{0}=4.9 \times 10^{-3} *(-12100 / \mathrm{T}) \\
\mathrm{K}_{\infty}=5.4 \times 10^{16} *(-13830 / \mathrm{T})\end{array}$ & {$[1],[6]$} \\
\hline $\mathrm{NO}_{3}+\mathrm{C}_{2} \mathrm{O}_{3}$ & $\mathrm{NO}_{2}+\mathrm{CH}_{3} \mathrm{O}_{2}$ & $4.0 \times 10^{-12}$ & [5] \\
\hline $\mathrm{C}_{2} \mathrm{O}_{3}+\mathrm{C}_{2} \mathrm{O}_{3}$ & $\mathrm{CH}_{3} \mathrm{O}_{2}+\mathrm{CH}_{3} \mathrm{O}_{2}$ & $2.9 \times 10^{-12} * \exp (500 / \mathrm{T})$ & [1] \\
\hline $\mathrm{C}_{2} \mathrm{O}_{3}+\mathrm{HO}_{2}$ & $0.4 \mathrm{CH}_{3} \mathrm{COOH}+0.4 \mathrm{O}_{3}$ & $4.3 \times 10^{-13} * \exp (1040 / \mathrm{T})$ & [5] \\
\hline $\mathrm{OH}+\mathrm{PAR}$ & $\begin{array}{l}0.87 \mathrm{XO}_{2}+0.11 \mathrm{HO}_{2}+0.11 \mathrm{ALD} 2+0.76 \\
\mathrm{ROR}+0.11 \mathrm{RXPAR}+0.13 \mathrm{XO}_{2} \mathrm{~N}\end{array}$ & $8.1 \times 10^{-13}$ & {$[1],[8]$} \\
\hline ROR & $\begin{array}{l}1.1 \mathrm{ALD} 2+0.96 \mathrm{XO}_{2}+0.04 \\
\mathrm{XO}_{2} \mathrm{~N}+0.02 \mathrm{ROR}^{2}+2.1 \\
\mathrm{RXPAR}+0.94 \mathrm{HO}_{2}\end{array}$ & $1.0 \times 10^{15} * \exp (-8000 / \mathrm{T})$ & {$[1],[8]$} \\
\hline ROR & $\mathrm{HO}_{2}$ & 1600.0 & [1] \\
\hline $\mathrm{OH}+\mathrm{C}_{2} \mathrm{H}_{4}(+\mathrm{M})$ & $\mathrm{HO}_{2}+1.56 \mathrm{HCHO}+0.22 \mathrm{ALD} 2+\mathrm{XO}_{2}$ & $\begin{array}{l}\mathrm{K}_{0}=1.0 \times 10^{-28} *(300 / \mathrm{T})^{4.5} \\
\mathrm{~K}_{\infty}=8.8 \times 10^{-16} *(-300 / \mathrm{T})^{0.85}\end{array}$ & [1],[2] \\
\hline $\mathrm{O}_{3}+\mathrm{C}_{2} \mathrm{H}_{4}$ & $\begin{array}{l}\mathrm{HCHO}+0.22 \mathrm{HO}_{2}+0.12 \mathrm{OH}+0.24 \\
\mathrm{CO}+0.52 \mathrm{HCOOH}\end{array}$ & $1.2 \times 10^{-14} * \exp (-2630 / \mathrm{T})$ & [5] \\
\hline $\mathrm{OH}+\mathrm{OLE}$ & $\begin{array}{l}0.8 \mathrm{HCHO}+0.95 \mathrm{ALD} 2+0.8 \\
\mathrm{XO}_{2}+1.57 \mathrm{HO}_{2}+0.7 \mathrm{RXPAR}+0.62 \\
\mathrm{CO}\end{array}$ & $5.2 \times 10^{-14} * \exp (-610 / \mathrm{T})$ & {$[1],[7]$} \\
\hline $\mathrm{O}_{3}+\mathrm{OLE}$ & $\begin{array}{l}0.5 \mathrm{ALD} 2+0.76 \mathrm{HO}_{2}+0.1 \\
\mathrm{OH}+0.95 \mathrm{CO}+0.74 \mathrm{HCHO}+0.22 \\
\mathrm{XO}_{2}+\mathrm{RXPAR}\end{array}$ & $8.5 \times 10^{-16} * \exp (1520 / \mathrm{T})$ & {$[1],[7]$} \\
\hline $\mathrm{NO}_{3}+\mathrm{OLE}$ & $\begin{array}{l}0.91 \mathrm{HO}_{2}+\mathrm{NO}_{2}+\mathrm{HCHO}+0.91 \\
\mathrm{ALD}_{2}+0.09 \mathrm{XO}_{2} \mathrm{~N}+\mathrm{RXPAR}+0.56 \\
\mathrm{HO}_{2}+0.56 \mathrm{CO}\end{array}$ & $4.6 \times 10^{-14} * \exp (400 / \mathrm{T})$ & {$[4],[7]$} \\
\hline $\mathrm{OH}+\mathrm{C}_{2} \mathrm{H}_{6}$ & $\begin{array}{l}0.991 \mathrm{ALD} 2+0.991 \mathrm{XO}_{2}+0.009 \\
\mathrm{XO}_{2} \mathrm{~N}+\mathrm{HO}_{2}\end{array}$ & $6.9 \times 10^{-12} * \exp (-1000 / \mathrm{T})$ & {$[1],[6]$} \\
\hline $\mathrm{OH}+\mathrm{C}_{2} \mathrm{H}_{5} \mathrm{OH}$ & $\begin{array}{l}\mathrm{ALD} 2+\mathrm{HO}_{2}+0.1 \mathrm{XO}_{2} \\
+0.1 \mathrm{HCHO}\end{array}$ & $3.0 \times 10^{-12} * \exp (20 / \mathrm{T})$ & {$[1],[3]$} \\
\hline $\mathrm{OH}+\mathrm{CH}_{3} \mathrm{COOH}$ & $\mathrm{CH}_{3} \mathrm{O}_{2}$ & $4.2 \times 10^{-14} * \exp (-855 / \mathrm{T})$ & {$[1],[6]$} \\
\hline $\mathrm{OH}+\mathrm{C}_{3} \mathrm{H}_{8}$ & $\mathrm{XO}_{2}$ & $7.6 \times 10^{-12} * \exp (-585 / \mathrm{T})$ & {$[3],[7]$} \\
\hline $\mathrm{OH}+\mathrm{C}_{3} \mathrm{H}_{6}$ & $\mathrm{XO}_{2}$ & $\begin{array}{l}\mathrm{K}_{0}=8.0 \times 10^{-27} *(-300 / \mathrm{T})^{3.5} \\
\mathrm{~K}_{\infty}=3.0 \times 10^{-11}\end{array}$ & {$[5],[7]$} \\
\hline $\mathrm{O}_{3}+\mathrm{C}_{3} \mathrm{H}_{6}$ & $\begin{array}{l}0.54 \mathrm{HCHO}+0.19 \mathrm{HO}_{2}+0.33 \\
\mathrm{OH}+0.56 \mathrm{CO}+0.5 \mathrm{ALD} 2+0.31 \\
\mathrm{CH}_{3} \mathrm{O}_{2}+0.25 \mathrm{HCOOH}\end{array}$ & $5.5 \times 10^{-15} * \exp (-1880 / \mathrm{T})$ & {$[6],[9]$} \\
\hline $\mathrm{NO}_{3}+\mathrm{C}_{3} \mathrm{H}_{6}$ & ORGNTR & $4.6 \times 10^{-13} * \exp (-1155 / \mathrm{T})$ & {$[6],[9]$} \\
\hline $\mathrm{OH}+\mathrm{ORGNTR}$ & $\begin{array}{l}\mathrm{HNO}_{3}+0.51 \mathrm{XO}_{2}+0.3 \mathrm{ALD} 2+0.9 \\
\mathrm{HO}_{2}+0.74 \mathrm{C}_{2} \mathrm{O}_{3}+0.74 \\
\mathrm{CH}_{3} \mathrm{O}_{2}+1.98 \mathrm{RXPAR}\end{array}$ & $5.9 \times 10^{-13} * \exp (-360 / \mathrm{T})$ & {$[1],[7]$} \\
\hline OH + TERPENE & $\begin{array}{l}1.22 \mathrm{HO}_{2}+1.25 \mathrm{XO}_{2}+0.25 \\
\mathrm{XO}_{2} \mathrm{~N}+1.22 \mathrm{HCHO}+5.0 \\
\mathrm{PAR}+0.47 \mathrm{ALD} 2+0.47 \mathrm{CO}\end{array}$ & $1.2 \times 10^{-11} * \exp (440 / \mathrm{T})$ & {$[3],[7]$} \\
\hline $\mathrm{O}_{3}+$ TERPENE & $\begin{array}{l}0.57 \mathrm{OH}+0.28 \mathrm{HO}_{2}+0.76 \\
\mathrm{XO}_{2}+0.18 \mathrm{XO}_{2} \mathrm{~N}+1.8 \\
\mathrm{HCHO}+0.211 \mathrm{CO}+6.0 \mathrm{PAR}+0.21 \\
\mathrm{ALD} 2+0.39 \mathrm{C}_{2} \mathrm{O}_{3}+0.39 \mathrm{CH}_{3} \mathrm{O}_{2}\end{array}$ & $6.3 \times 10^{-16} * \exp (-580 / \mathrm{T})$ & {$[3],[7]$} \\
\hline
\end{tabular}


Table A1. Continued.

\begin{tabular}{|c|c|c|c|}
\hline Reactants & Products & Rate expression & Reference \\
\hline $\mathrm{NO}_{3}+\mathrm{TERPENE}$ & $\begin{array}{l}0.47 \mathrm{NO}_{2}+0.75 \mathrm{HO}_{2}+1.03 \\
\mathrm{XO}_{2}+0.25 \mathrm{XO}_{2} \mathrm{~N}+0.47 \\
\mathrm{ALD} 2+0.53 \mathrm{ORGNTR}+0.47 \\
\mathrm{CO}+6.0 \mathrm{PAR}\end{array}$ & $1.2 \times 10^{-12} * \exp (490 / \mathrm{T})$ & {$[3],[7]$} \\
\hline OH + ISOPRENE & $\begin{array}{l}0.912 \mathrm{ISPD}+0.5 \mathrm{HO}_{2}+0.629 \\
\mathrm{HCHO}+0.991 \mathrm{XO}_{2}+0.088 \mathrm{XO}_{2} \mathrm{~N}\end{array}$ & $2.7 \times 10^{-11} * \exp (390 . / \mathrm{T})$ & {$[3],[4],[7]$} \\
\hline $\mathrm{O}_{3}+$ ISOPRENE & $\begin{array}{l}0.65 \mathrm{ISPD}+0.6 \mathrm{HCHO}+0.2 \\
\mathrm{XO}_{2}+0.066 \mathrm{HO}_{2}+0.266 \\
\mathrm{OH}+0.2 \mathrm{C}_{2} \mathrm{O}_{3}+0.15 \mathrm{ALD} 2+0.35 \\
\mathrm{PAR}+0.066 \mathrm{CO}\end{array}$ & $1.04 \times 10^{-14} * \exp (-1995 . / \mathrm{T})$ & {$[3],[7]$} \\
\hline $\mathrm{NO}_{3}+$ ISOPRENE & $\begin{array}{l}0.2 \mathrm{ISPD}+\mathrm{XO}_{2}+0.8 \mathrm{HO}_{2}+0.8 \\
\mathrm{ORGNTR}+0.8 \\
\mathrm{ALD} 2+2.4 \mathrm{PAR}+0.2 \mathrm{NO}_{2}\end{array}$ & $3.15 \times 10^{-12} * \exp (-450 . / \mathrm{T})$ & {$[3],[7]$} \\
\hline $\mathrm{OH}+\mathrm{ISPD}$ & $\begin{array}{l}0.167 \mathrm{HCHO}+0.503 \mathrm{HO}_{2}+0.168 \\
\mathrm{CH}_{3} \mathrm{COCHO}+0.334 \mathrm{CO}+0.273 \\
\mathrm{ALD} 2+0.498 \mathrm{C}_{2} \mathrm{O}_{3}+0.713 \\
\mathrm{XO}_{2}+1.565 \mathrm{PAR}\end{array}$ & $\begin{array}{l}\text { Average of: } \\
1.86 \times 10^{-11} * \exp (175 / \mathrm{T}) \\
2.6 \times 10^{-12} * \exp (610 / \mathrm{T})\end{array}$ & {$[1],[7]$} \\
\hline $\mathrm{O}_{3}+\mathrm{ISPD}$ & $\begin{array}{l}0.15 \mathrm{HCHO}+0.114 \mathrm{C}_{2} \mathrm{O}_{3}+0.85 \\
\mathrm{CH}_{3} \mathrm{COCHO}+0.154 \mathrm{HO}_{2}+0.268 \\
\mathrm{OH}+0.064 \mathrm{XO}_{2}+0.225 \\
\mathrm{CO}+0.02 \mathrm{ALD} 2+0.36 \mathrm{PAR}\end{array}$ & $\begin{array}{l}\text { Average of: } \\
8.5 \times 10^{-16} * \exp (-1520 / \mathrm{T}) \\
1.4 \times 10^{-15} * \exp (-2100 / \mathrm{T})\end{array}$ & {$[3],[7]$} \\
\hline $\mathrm{NO}_{3}+\mathrm{ISPD}$ & $\begin{array}{l}0.85 \text { ORGNTR }+0.357 \\
\mathrm{ALD} 2+0.282 \mathrm{HCHO}+0.643 \\
\mathrm{CO}+0.075 \mathrm{C}_{2} \mathrm{O}_{3}+0.15 \\
\mathrm{HNO}_{3}+0.075 \mathrm{XO}_{2}+0.925 \\
\mathrm{HO}_{2}+1.282 \mathrm{PAR}^{2}\end{array}$ & $\begin{array}{l}\text { Average of: } \\
6.0 \times 10^{-16} \\
3.4 \times 10^{-15}\end{array}$ & {$[3],[7]$} \\
\hline $\mathrm{OH}+\mathrm{CH}_{3} \mathrm{COCH}_{3}$ & $\mathrm{ACO}_{2}$ & $\begin{array}{l}\text { Sum of: } \\
8.8 \times 10^{-12} * \exp (-1320 / \mathrm{T}) \\
1.7 \times 10^{-14} * \exp (423 / \mathrm{T})\end{array}$ & {$[3],[7]$} \\
\hline $\mathrm{ACO}_{2}+\mathrm{HO}_{2}$ & $\mathrm{ROOH}$ & $1.0 \times 10^{-11}$ & {$[3],[7]$} \\
\hline $\mathrm{ACO}_{2}+\mathrm{CH}_{3} \mathrm{O}_{2}$ & $\begin{array}{l}0.5 \mathrm{CH}_{3} \mathrm{OH}+0.5 \mathrm{HO}_{2}+0.7 \\
\mathrm{ALD} 2+0.2 \mathrm{C}_{2} \mathrm{O}_{3}+0.5 \mathrm{CH}_{3} \mathrm{COCHO}\end{array}$ & $3.8 \times 10^{-12}$ & {$[6],[7]$} \\
\hline $\mathrm{ACO}_{2}+\mathrm{NO}$ & $\mathrm{NO}_{2}+\mathrm{C}_{2} \mathrm{O}_{3}+\mathrm{HCHO}+\mathrm{HO}_{2}$ & $8.0 \times 10^{-12}$ & {$[6],[7]$} \\
\hline $\mathrm{HO}_{2}+\mathrm{XO}_{2}$ & $\mathrm{ROOH}$ & $7.5 \times 10^{-13} * \exp (700 / \mathrm{T})$ & {$[1]$} \\
\hline $\mathrm{NO}+\mathrm{XO}_{2}$ & $\mathrm{NO}_{2}$ & $2.6 \times 10^{-12} * \exp (365 / \mathrm{T})$ & [1] \\
\hline $\mathrm{NO}_{3}+\mathrm{XO}_{2}$ & $\mathrm{NO}_{2}$ & $2.5 \times 10^{-12}$ & {$[5]$} \\
\hline $\mathrm{NO}+\mathrm{XO}_{2} \mathrm{~N}$ & ORGNTR & $2.6 \times 10^{-12} * \exp (365 / \mathrm{T})$ & [1] \\
\hline $\mathrm{HO}_{2}+\mathrm{XO}_{2} \mathrm{~N}$ & $\mathrm{ROOH}$ & $8.0 \times 10^{-12} * \exp (-2060 / \mathrm{T})$ & [1] \\
\hline $\mathrm{XO}_{2}+\mathrm{XO}_{2}$ & & $1.6 \times 10^{-12} * \exp (-2200 / \mathrm{T})$ & [1] \\
\hline $\mathrm{XO}_{2}+\mathrm{XO}_{2} \mathrm{~N}$ & & $6.8 \times 10^{-14}$ & {$[1]$} \\
\hline $\mathrm{XO}_{2} \mathrm{~N}+\mathrm{XO}_{2} \mathrm{~N}$ & & $6.8 \times 10^{-14}$ & {$[1],[6]$} \\
\hline PAR + RXPAR & & $8.0 \times 10^{-11}$ & [8] \\
\hline $\mathrm{DMS}+\mathrm{OH}$ & $\mathrm{SO}_{2}$ & $1.1 \times 10^{-11} * \exp (-240 / \mathrm{T})$ & [2] \\
\hline $\mathrm{DMS}+\mathrm{OH}$ & $0.75 \mathrm{SO}_{2}+\mathrm{MSA}$ & $\begin{array}{l}1.0 \times 10^{-39} * \exp (5820 / \mathrm{T}) \\
5.0 \times 10^{-30} * \exp (6280 / \mathrm{T})\end{array}$ & {$[2]$} \\
\hline $\mathrm{DMS}+\mathrm{NO}_{3}$ & $\mathrm{SO}_{2}$ & $1.9 \times 10^{-13} * \exp (520 / \mathrm{T})$ & {$[10]$} \\
\hline $\mathrm{OH}+\mathrm{SO}_{2}$ & $\mathrm{SO}_{4}^{2-}$ & $\begin{array}{l}\mathrm{K}_{0}=3.3 \times 10^{-31} *(300 / \mathrm{T})^{4.3} \\
\mathrm{~K}_{\infty}=1.6 \times 10^{-12} *(300 / \mathrm{T})\end{array}$ & {$[2]$} \\
\hline $\mathrm{OH}+\mathrm{NH}_{3}$ & $\mathrm{NH}_{2}$ & $1.7 \times 10^{-12} * \exp (-710 / \mathrm{T})$ & [2] \\
\hline $\mathrm{NO}+\mathrm{NH}_{2}$ & & $4.0 \times 10^{-12} * \exp (450 / \mathrm{T})$ & [2] \\
\hline $\mathrm{NO}_{2}+\mathrm{NH}_{2}$ & & $2.1 \times 10^{-12} * \exp (650 / \mathrm{T})$ & [2] \\
\hline $\mathrm{HO}_{2}+\mathrm{NH}_{2}$ & & $3.4 \times 10^{-11}$ & [2] \\
\hline $\mathrm{O}_{2}+\mathrm{NH}_{2}$ & & $6.0 \times 10^{-21}$ & [2] \\
\hline $\mathrm{O}_{3}+\mathrm{NH}_{2}$ & & $4.3 \times 10^{-12} * \exp (-930 / \mathrm{T})$ & [2] \\
\hline
\end{tabular}


Table A2. The photolytic reaction rates included in the modified CB05 chemical mechanism. The reaction products $\mathrm{O}_{2}$ and $\mathrm{H}_{2} \mathrm{O}$ are not shown. The stiochiometery of each photolytic reaction is taken from Yarwood et al. (2005) except for the photolysis of $\mathrm{O}_{2}$. The source of the absorption co-efficients and quantum yields are thus: [1] Sander et al. (2011), [2] Matsumi et al. (2002), [3] Atkinson et al. (2006). Further details: [a] absorption cross section for a C4 mono-nitrate are adopted (Roberts and Fayer, 1989), [b] the absorption cross section for $\mathrm{CH}_{3} \mathrm{CHO}$ is adopted, [c] set equal to the photolysis frequency of $\mathrm{CH}_{3} \mathrm{OOH}$ due a lack of laboratory measurements and [d] the absorption cross sections are set equal to an average of methyl vinyl ketone and methacrolein.

\begin{tabular}{|c|c|c|}
\hline Chemical species & Products & Reference \\
\hline $\mathrm{O}_{3}$ & $\mathrm{NO}_{2}$ & {$[1,2]$} \\
\hline $\mathrm{NO}_{2}$ & $\mathrm{NO}+\mathrm{O}_{3}$ & [1] \\
\hline $\mathrm{H}_{2} \mathrm{O}_{2}$ & $\mathrm{OH}+\mathrm{OH}$ & [1] \\
\hline $\mathrm{HNO}_{3}$ & $\mathrm{HNO}_{3}$ & [1] \\
\hline $\mathrm{HNO}_{4}$ & $\mathrm{NO}_{3}$ & [1] \\
\hline $\mathrm{N}_{2} \mathrm{O}_{5}$ & $\mathrm{NO}_{2}+\mathrm{NO}_{3}$ & [1] \\
\hline $\mathrm{CH}_{2} \mathrm{O}$ & $\mathrm{CO}$ & [3] \\
\hline $\mathrm{CH}_{2} \mathrm{O}$ & $\mathrm{CO}+\mathrm{HO}_{2}+\mathrm{HO}_{2}$ & [3] \\
\hline $\mathrm{CH}_{3} \mathrm{OOH}$ & $\mathrm{HCHO}+\mathrm{OH}+\mathrm{HO}_{2}$ & [1] \\
\hline PAN & $\mathrm{C}_{2} \mathrm{O}_{3}+\mathrm{NO}_{2}$ & [1] \\
\hline $\mathrm{NO}_{3}$ & $\mathrm{NO}_{2}+\mathrm{O}_{3}$ & [1] \\
\hline $\mathrm{NO}_{3}$ & $\mathrm{NO}$ & [1] \\
\hline ORGNTR ${ }^{[a]}$ & $\mathrm{NO}_{2}+0.51 \mathrm{XO}_{2}+0.3 \mathrm{ALD} 2+0.9 \mathrm{HO}_{2}+0.74 \mathrm{C}_{2} \mathrm{O}_{3}+0.74 \mathrm{CH}_{3} \mathrm{O}_{2}+1.98 \mathrm{RXPAR}$ & [3] \\
\hline ALD2 [b] & $\mathrm{CH}_{3} \mathrm{O}_{2}+\mathrm{CO}+2 \mathrm{HO}_{2}$ & [3] \\
\hline $\mathrm{ROOH}^{[\mathrm{c}]}$ & $\mathrm{OH}+0.5 \mathrm{XO}_{2}+0.3 \mathrm{ALD} 2+0.9 \mathrm{HO}_{2}+0.74 \mathrm{C}_{2} \mathrm{O}_{3}+0.74 \mathrm{CH}_{3} \mathrm{O}_{2}+1.98 \mathrm{RXPAR}$ & [1] \\
\hline $\mathrm{CH}_{3} \mathrm{COCHO}$ & $\mathrm{C}_{2} \mathrm{O}_{3}+\mathrm{HO}_{2}+\mathrm{CO}$ & [1] \\
\hline $\mathrm{O}_{2}$ & $2 \mathrm{O}\left({ }^{3} \mathrm{P}\right)$ & [1] \\
\hline ISPD $^{[\mathrm{d}]}$ & $0.333 \mathrm{CO}+0.067 \mathrm{ALD} 2+0.9 \mathrm{HCHO}+0.832 \mathrm{PAR}+1.033 \mathrm{HO}_{2}+0.7 \mathrm{XO}_{2}+0.967 \mathrm{C}_{2} \mathrm{O}_{3}$ & [3] \\
\hline $\mathrm{CH}_{3} \mathrm{COCO}_{3}$ & $\mathrm{CO}+2 \mathrm{CH}_{3} \mathrm{O}_{2}$ & [3] \\
\hline $\mathrm{CH}_{3} \mathrm{COCO}_{3}$ & $\mathrm{C}_{2} \mathrm{O}_{3}+\mathrm{CH}_{3} \mathrm{O}_{2}$ & [3] \\
\hline
\end{tabular}

Table A3. Details concerning the chemical data that is used for the calculation of heterogeneous scavenging rates for the additional soluble organic species that are included in the modified CB05 chemical mechanism. Here $k_{H}^{\theta}$ is the Henry's law co-efficient at $298.15^{\circ} \mathrm{K}, \Delta$ solnH is the enthalpy of solution and $R$ the gas constant. For the inorganic species and other organic species the reader is referred to Huijnen et al. (2010).

\begin{tabular}{lccl}
\hline Chemical species & $k_{H}^{\theta}[\mathrm{M} / \mathrm{atm}]$ & $\frac{\Delta_{\text {soln }} H}{R}$ & Reference \\
\hline $\mathrm{CH}_{3} \mathrm{OH}$ & 220 & 5200 & Snider and Dawson (1985) \\
$\mathrm{CH}_{3} \mathrm{CH}{ }_{2} \mathrm{OH}$ & 190 & 6600 & Snider and Dawson (1985) \\
$\mathrm{HCOOH}$ & 8900 & 6100 & Johnson et al. (1996) \\
$\mathrm{CH}_{3} \mathrm{COOH}$ & 4100 & 6300 & Johnson et al. (1996) \\
$\mathrm{CH}_{3} \mathrm{COCH}_{3}$ & 35 & 3800 & Zhou and Mopper (1990) \\
\hline
\end{tabular}

Acknowledgements. The authors acknowledge the NOAA ESRL team for providing the surface flask measurements of $\mathrm{CO}$ and the MOZAIC consortium for allowing the use of the flight data taken at various airports across the world. MOZAIC is presently funded by INSU-CNRS (France), Météo-France and Forschungszentrum Jülich (Germany). We also acknowledge the EMEP European monitoring network for making their surface measurement data freely available. We also thank $\mathrm{C}$. Teeven for adapting the IDL code for analysing the emission inventories.

Edited by: R. Holzinger

\section{References}

Archibald, A. T., Jenkin, M. E., and Shallcross, D. E.: An isoprene mechanism intercomparison, Atms. Environ., 44, 53565364, 2010.

Arneth, A., Monson, R. K., Schurgers, G., Niinemets, Ü., and Palmer, P. I.: Why are estimates of global terrestrial isoprene emissions so similar (and why is this not so for monoterpenes)?, Atmos. Chem. Phys., 8, 4605-4620, doi:10.5194/acp-8-4605-2008, 2008.

Arneth, A., Schurgers, G., Lathiére, J., Duhl, T., Hewitt, C. N., Martin, M., and Guenther, A.: Global terrestrial isoprene emission models: sensitivity to variability in climate and vegetation, Atmos. Chem. Phys., 11, 8037-8052, 
doi:10.5194/acp-11-8037-2011, 2011.

Ashworth, K., Wild, O., and Hewitt, C. N.: Sensitivity of isoprene emissions estimated using MEGAN to the time resolution of input climate data, Atmos. Chem. Phys., 10, 1193-1201, doi:10.5194/acp-10-1193-2010, 2010.

Atkinson, R.: Atmospheric chemistry of VOCs and $\mathrm{NO}_{\mathrm{x}}$, Atmos. Environ., 34, 2063-2101, 2000.

Atkinson, R., Baulch, D. L., Cox, R. A., Crowley, J, N., Hampson, R. F., Hynes, R. G., Jenkin, M. E., Rossi, M. J. and Troe, J.: evaluated kinetic and photochemical data for atmospheric chemistry: Volume $\mathrm{I}$ - gas phase reactions of $\mathrm{O}_{\mathrm{x}}, \mathrm{HO}_{\mathrm{x}}, \mathrm{NO}_{\mathrm{x}}$ and $\mathrm{SO}_{\mathrm{x}}$, species, Atmos. Chem. Phys., 4, 1461-1738, doi:10.5194/acp-41461-2004, 2004.

Atkinson, R., Baulch, D. L., Cox, R. A., Crowley, J. N., Hampson, R. F., Hynes, R. G., Jenkin, M. E., Rossi, M. J., Troe, J., and IUPAC Subcommittee: Evaluated kinetic and photochemical data for atmospheric chemistry: Volume II - gas phase reactions of organic species, Atmos. Chem. Phys., 6, 3625-4055, doi:10.5194/acp-6-3625-2006, 2006.

Baker, A. K., Schuck, T. J., Brenninkmeijer, C. A. M., Rauthe-Schöch, A., Slemr, F., van Velthoven, P. F. J., and Lelieveld, J.: Estimating the contribution of monsoon-related biogenic production of methane emissions from South Asia using CARIBIC observations, Geophys. Res. Lett., L10813, doi:10.1029/2012GL051756, 2012.

Barret, B., Williams, J. E., Bouarar, I., Yang, X., Josse, B., Law, K., Pham, M., Le Flochmoën, Liousse, C., Peuch, V.-H., Carver, G. D., Pyle, J. A., Sauvage, B., van Velthoven, P., Schlager, H., Mari, C., and Cammas, J.-P.: Impact of West African Monsoon convective transport and lightning $\mathrm{NO}_{\mathrm{x}}$ production upon the upper tropospheric composition: a multi-model study, Atmos. chem. Phys. 10, 5719-5738, doi:10.5194/acp-10-5719-2010, 2010.

Brenninkmeijer, C. A. M., Koeppel, C., Röckmann, T., Scharffe, D. S., Bräunlich, M., and Gros, V.: Absolute measurement of the abundance of atmospheric carbon monoxide, J. Geophys. Res., 106, 10003-10010, 2001.

Castellanos, P. and Boersma, K. F.: Reductions in nitrogen oxides over Europe driven by environmental policy and economic recession, Sci. Reports, 2 (265), doi:10.1038/srep00265, 2012.

Colomb, A., Gros, V., Alvain, S., Sarda-Esteve, R., Bonsang, B., Moulin, C., Klupfel, T., and Williams, J.: Variation of atmospheric volatile organic compounds over the Southern Indian Ocean (30-49 S), Environ. Chem., 6, 70-82, 2009.

Curci, G., Beekman, M., Vautard, R., Smiatek, G., Steinbrecher, R., Theloke, J. and Friedrich, R.: Modelling stidy of the impact of isoprene and terpene biogenic emissions on Europena ozone levels, Atms. Environ., 43, 1444-1455, 2009.

Davidson, E. A. and Kingerlee, W.: A global inventory of nitric oxide emissions from soils, Nutr. Cycl. Agroecosys., 48, 37-50, 1997.

Dalsøren, S. B. and Isaksen, I. S. A.: CTM study of changes in tropospheric hydroxyl distribution 199-2001 and its impact on methane, Geophys. Res. Lett., 33, L23811, doi:10.1029/2006GL027295, 2006.

Dee, D. P., Uppala, S. M., Simmons, A. J., Berrisford, P., Poli, P., Kobayashi, S., Andrae, U., Balmaseda, M. A., Balsamo, G., Bauer, P., Bechtold, P., Beljaars, A. C. M., van de Berg, L., Bidlot, J., Bormann, N., Delsol, C., Dragani, R., Fuentes, M., Geer, A. J., Haimberger, L., Healy, S. B., Hersbach, H., Hólm, E. V.,
Isaksen, L., Kållberg, P., Köhler, M., Matricardi, M., McNally, A. P., Monge-Sanz, B. M., Morcrette, J.-J., Park, B.-K., Peubey, C., de Rosnay, P., Tavolato, C., Thépaut, J.-N., and Vitart, F.: The ERA-Interim reanalysis: configuration and performance of the data assimilation system, Q. J. Roy. Meteorol. Soc., 137, 656, 553-597, 2011.

Dlugokencky, E. J., Nisbet, E. G., Fisher, R., and Lowry, D.: Global atmospheric methane: budget, changes and dangers, Phil. Trans. R. Soc. A, 369, 2058-2072, doi:10.1098/rsta.2010.0341, 2011.

Fiore, A. M., Levy II, H., and Jaffe, D. A.: North American isoprene influence on intercontinental ozone pollution, Atmos. chem. Phys., 11, 1697-1710, doi:10.5194/acp-11-1697-2011, 2011.

Fischer, E. V., Jacob, D. J., Millet, D. B., Yantosca, R. M., and Mao, J.: The role of the ocean in the global atmospheric budget of acetone, Geophys. Res. Lett., 39, L01807, doi:10.1029/2011GL050086, 2012.

Folberth, G. A., Hauglustaine, D. A., Lathiére, J., and Brocheton, F.: Interactive chemistry in the Laboratoire de Météorologie Dynamique general circulation model: model description and impact analysis of biogenic hydrocarbons on tropospheric chemistry, Atmos. Chem. Phys., 6, 2273-2319, doi:10.5194/acp-62273-2006, 2006.

Fortuin, J. P. F. and Kelder, H.: An ozone climatology based on ozonesonde and satellite measurements, J. Geophys. Res., 103, 31709-31734, 1998.

Fowler, D., Pilegaard, K., Sutton, M. A., Ambus, P., Raivonen, M., Duyzer, J., Simpson, D., Fagerli, H., Fuzzi, S., Schjoerring, J. K., Granier, C., Neftel, A., Isaksen, I. S. A., Laj, P., Maione, M., Monks, P. S., Burkhardt, J., Daemmgen, U., Neirynck, J., Personne, E., Wichink-Kruit, R., Butterbach-Bahl, K., Flechard, C., Tuovinen, J. P., Coyle, M., Gerosa, G., Loubet, B., Altimir, N., Gruenhage, L., Ammann, C., Cieslik, S., Paoletti, E., Mikkelsen, T. N., Ro-Poulsen, H., Cellier, P., Cape, J. N., Horváth, L., Loreto, F., Niinemets, U, Palmer, P. I., Rinne, J., Misztal, Nemitz, E., Nilsson, D., Pryor, S., Gallagher, M. W., Vesala, T., Skiba, U., Brüggemann, N., Zechmeister-Boltenstern, S., Williams, J., O’Dowd, C., Facchini, M. C., de Leeuw, G., Flossman, A., Chaumerliac, N., and Erisman, J. W.: Atmospheric composition change: Ecosystems-Atmosphere interactions, Atms. Environ., 43, 5193-5267, 2009.

Gantt, B., Meskhidze, N., and Kamykowski, D.: A new physicallybased quantification of marine isoprene and primary organic aerosol emissions, Atmos. Chem. Phys., 9, 4915-4927, doi:10.5194/acp-9-4915-2009, 2009.

Ganzeveld, L. and Lelieveld, J.: Dry deposition parameterization in a chemistry general circulation model and its influence on the distribution of reactive gases, J. Geophys. Res., 100, 20999 21012, 1995.

Granier, C., Guether, A., Lamarque, J. F., Mieville, A., Muller, J. F., Olivier, J., Orlando, J., Peters, J., Petron, G., Tyndall, G., and Wallens, S.: POET - a database of surface emissions of ozone precursors, online available at: http://www.aero.jussieu.fr/ project/ACCENT/POET.php, last access: 26.02.13, 2005.

Granier, C., Bessagnet, B., Bond, T., D’Aniola, A., Denier von der Gon, H., Frost, G. J., Heil, A., kaiser, J. W., Kinne, S., Klimont, Z., Kloster, S., Lamarque, J.-F., Liousse, C., Masui, T., Meleuax, F., Mieville, A., Ohara, T., Raut, J.-C., Riahi, K., Schultz, M. G., Smith, S. J., Thompson, A., van Aardenne, J., van der Werf, G. R., and van Vuuren, D. P.: Evolution of anthropogenic and 
biomass burning emission of air pollutants at global and regional scales during the 1980-2010 period, Clim. Change, 109, 163190, doi:10.1007/s10584-011-0154-1, 2011.

Guenther, A., Hewitt, C. N., Erickson, D., Fall, R., Geron, C., Graedel, T., Harley, P., Klinger, L., Lerdau, M., McKay, W. A., Pierce, T., Scholes, B., Steinbrecher, R., Tallamraju, R., Taylor, J., and Zimmerman, P.: A global model of natural volatile organic compound emissions, J. Geophys. Res.-Atmos., 100, 8873-8892, 1995.

Guenther, A., Karl, T., Harley, P., Wiedinmyer, C., Palmer, P. I., and Geron, C.: Estimates of global terrestrial isoprene emissions using MEGAN (Model of Emissions of Gases and Aerosols from Nature), Atmos. Chem. Phys., 6, 3181-3210, doi:10.5194/acp-63181-2006, 2006.

Guenther, A. B., Jiang, X., Heald, C. L., Sakulyanontvittaya, T., Duhl, T., Emmons, L. K., and Wang, X.: The Model of Emissions of Gases and Aerosols from Nature version 2.1: an extended and updated framework for modeling biogenic emissions, Geosci. Model. Dev., 5, 1471-1492, doi:10.5194/gmd-5-14712012, 2012.

Gupta, M. L., Cicerone, R. J., Blake, D. R., Rowland, F. S., and Isaksen, I. S. A.: global atmospheric distributions and source strengths of light hydrocarbons and tetrachloroethene, J. Geophys. Res., 103, 28219-28325, 1998.

Hauglustaine, D. A, Lathiére, J., Szopa, S., and Folberth, G. A.: Future tropospheric ozone simulated with a climatechemistry-biosphere model, Geophys. Res. Letts., 32, L24807, doi:10.1029/2005GL024031, 2005.

Hertel, O., Berkowicz, R., and Christensen, J.: Test of two numerical schemes for use in atmospheric transport-chemistry models Atmos. Environ., 27A, 2591-2611, 1993.

Hewitt, C. N., Ashworth, K., Boynard, A., Guenther, A., Langford, B., MacKenzie, A. R., Misztal, P. K., Nemitz, E., Owen, S. M., Possell, M., Pugh, T. A. M., Ryan, A. C., and Wild, O.: Ground-level ozone influenced by circadian control of isoprene emissions, Nature Geosci., 4, 671-674, doi:10,1038/ngeo1271, 2011.

Hoor, P., Borken-Kleefeld, J., Caro, D., Dessens, O., Endresen, O., Gauss, M., Grewe, V., Hauglustaine, D., Isaksen, I. S. A., Jöckel, P., Lelieveld, J., Myhre, G., Meijer, E., Olivie, D., Prather, M., Schnadt Poberaj, C., Shine, K. P., Staehelin, J., Tang, Q., van Aardenne, J., van Velthoven, P., and Sausen, R.: The impact of traffic emissions on atmospheric ozone and $\mathrm{OH}$ : results from QUANTIFY, Atmos. Chem. Phys., 9, 3113-3136, doi:10.5194/acp-9-3113-2009, 2009.

Horowitz, L. W.: Pat, present and future concentrations of tropospheric ozone and aerosols: methodology, ozone evaluation, and sensitivity to aerosol wet removal, J. Geophys. Res., 111, D22211, doi:10.1029/2005JD006937, 2006.

Horowitz, L. W., Walters, S., Mauzerall, D. L., Emmons, L. K., Rasch, P. J., Granier, C., Tie, X., Lamarque, J.-F., Schultz, M. G., Tyndall, G. S., Orlando, J. J., and Brasseur, G. P.: A global simulation of tropospheric ozone and related tracers, Description and Evaluation of MOZART version 2, J. Geophys. Res., 108, 4784, doi:10.1029/2002JD002853, 2003.

Houweling, S., Dentener, F. J., and Lelieveld, J.: The impact of nonmethane hydrocarbon compounds on tropospheric photochemistry, J. Geophys. Res., 103, 10673-10696, 1998.
Houweling, S., Röckmann, T., Aben, I., Keppler, F., Krol, M., Meirink, J. F., Dlugokencky, E. J., and Frankenberg, C.: Atmospheric constraints on global emissions of methane from plants, Geophys. Res. Lett., 33, L15821, doi:10.1029/2006GL026162, 2006.

Huijnen, V., Williams, J. E., van Weele, M., van Noije, T., Krol, M., Dentener, F., Segers, A., Houweling, S., Peters, W., de Laat, J., Boersma, F., Bergamaschi, P., van Velthoven, P., Le Sager, P., Eskes, H., Alkemade, F., Scheele, R., Nédelec, P., and Pätz, H.-W.: The global chemistry transport model TM5: description and evaluation of the tropospheric chemistry version 3.0, Geosci. Model Dev., 3, 445-473, doi:10.5194/gmd-3-445-2010, 2010.

Im, U., Markakis, K., Poupkou, A., Melas, D., Unal, A., Gerasopoulos, E., Daskalakis, N., Kindap, T., and Kanakidou, M.: The impact of temperature changes on summer time ozone and its precursors in the Eastern Mediterranean, Atmos. Chem. Phys., 11, 3847-3864, doi:10.5194/acp-11-3847-2011, 2011.

Jansen, R. and De Serves, C.: Isoprene emissions from boreal wetlands in Scandinavia, J. Geophys. Res., 103, 25513-25517, doi:10.1029/98JD01857, 1998.

Jenkin, M. E. and Clemitshaw, K. C.: Ozone and other secondary pollutants: chemical processes governing their formation in the planetary boundary layer, Atms. Environ., 34, 2499-2527, 2000.

Johnson, B. J., Betterton, E. A., and Craig, D.: Henry's law coefficients of formic and acetic acids, J. Atmos. Chem., 24, 113-119, 1996.

Khalil, M. A. K.: Preface. Atmopsheric carbon monoxide, Chemosphere: Global Change Sci., 1, IX-XI, 1999,

Lamarque, J.-F., Bond, T. C., Eyring, V., Granier, C., Heil, A., Klimont, Z., Lee, D., Liousse, C., Mieville, A., Owen, B., Schultz, M. G., Shindell, D., Smith, S. J., Stehfest, E., van Aardenne, J., Cooper, O. R., Kainuma, M., Mahowlad, N., McConnell, J. R., Naik, V., Riahi, K., and van Vuuren, D. P.: Historical (1850-2000) gridded anthropogenic and biomass burning emission of reactive gases and aerosols: methodology and application, Atmos. Chem. Phys., 10, 7017-7039, doi:10.5194/acp10-7017-2010, 2010.

Lambert, G. and Schmidt, S.: Re-evaluation of the oceanic flux of methane uncertainties and long-term variations, Chemosphere, 26, 579-589, 1993.

Lathiére, J., Hauglustaine, D. A., De Noblet-Ducoudré, N., Krinner, G., and Folberth, G. A.: Past and future changes in biogenic volatile organic compound emissions simulated with a global dynamic vegetation model, Geophys. Res. Letts., 32, L20818, doi:10.1029/2005GL024164, 2005.

Lathiére, J., Hauglustaine, D. A., Friend, A. D., De NobletDucoudré, N., Viovy, N., and Folberth, G. A.: Impact of climate variability and land use changes on global biogenic volatile organic compound emissions, Atmos. Chem. Phys., 6, 2129-2146, doi:10.5194/acp-6-2129-2006, 2006.

Li, G., Zhang, R., Fan, J., and Tie, X.: Impacts of biogenic emissions on photochemical ozone production in Houston, Texas, J. Geophys. Res., 112, D10309, doi:10.1029/2006JD007924, 2007.

Lindfors, V. and Laurila, T.: Biogenic volatile organic compound (VOC) emissions from forests in Finland, Boreal. Environ. Res., 5, 95-113, 2000.

Luo, G. and Yu, F.: A numerical evaluation of global oceanic emissions of $\alpha$-pinene and isoprene, Atmos. Chem. Phys., 10, 2007 2015, doi:10.5194/acp-10-2007-2010, 2010. 
Marais, E. A., Jacob, D. J., Kurosu, T. P., Chance, K., Murphy, J. G., Reeves, C., Mills, G., Casadio, S., Millet, D. B., Barkley, M. P., Paulot, F., and Mao, J.: Isoprene emissions in Africa inferred from OMI observations of formaldehyde columns, Atmos. Chem. Phys., 12, 6219-6235, doi:10.5194/acp-12-62192012, 2012.

Marenco, A., Thouret, V., Nédélec, P., Smit, H., Helten, M., Kley, D., karcher, F., Simon, P., Law, K., Pyle, J., Poschmann, G., von Wrede, R., Hume, C., and Cook, T.: Measurement of ozone and water vapor by Airbus in-service aircraft: The MOZAIC airborne program, An overview, J. Geophys. Res., 103, 25631-25642, 1998.

Matsumi, Y., Comes, F. J., Hancock, G., Hofzumahus, A., Hynes, A. J., Kawasaki, M., and Ravishankara, A. R.: Quantum yields for the production of $\mathrm{O}(1 \mathrm{D})$ in the ultraviolet photolysis of ozone: recommendation based on evaluation of laboratory data, J. Geophys. Res., 107, 4024, doi:10.1029/2001JD000510, 2002.

Meijer, E. W., van Velthoven, P. F. J., Brunner, D. W., Huntrieser, H., and Kelder, H.: Improvement and evaluation of the parameterisation of nitrogen oxide production by lightning, Phys. Chem. Earth, 26, 557-583, 2001.

Niinemets, U., Monson, R. K., Arneth, A., Ciccioli, P., Kesselmeier, J., Kuhn, U., Noe, S. M., Peñuelas, J., and Staudt, M.: The leaflevel emission factor of volatile isoprenoids: caveats, model algorithms, response shapes and scaling, Biogeosciences, 7, 18091832, doi:10.5194/bg-7-1809-2010, 2010.

Novelli, P. C., Masarie, K. A., and Lang, P. M.: Distributions and recent trends of carbon monoxide in the lower troposphere, J. Geophys. Res. 103, 19015-19033, 1998.

Novelli, P. C., Masarie, K. A., Lang, P. M., Hall, B. D., Myers, R. C., and Elkins, J. W.: Reanalysis of tropospheric CO trends: Effects of 1997-1998 wildfires, J. Geophys. Res., 108, 4464, doi:10.1029/2002JD003031, 2003.

Ohara, T., Akimoto, H., Kurokawa, J., Horii, N., Yamaji, K., Yan, X., and Hayasaka, T.: An Asian emission inventory of anthropogenic emission sources for the period 1980-2020, Atmos. Chem. Phys., 7, 4419-4444, doi:10.5194/acp-7-4419-2007, 2007.

Olson, K.: Reducing methane emissions from beef cow herds in range-based management systems. Ruminant Livestock Efficiency Program Conference Proceedings, Knoxville, Tennesse, EPA, USDA, August 1997.

Ordñez, C., Elguindi, N., Stein, O., Huijnen, V., Flemming, J., Inness, A., Flentje, H., Katragkou, E., Moinat, P., Peuch, V.-H., Segers, A., Thouret, V., Athier, G., van Weele, M., Zerefos, C. S., Cammas, J.-P., and Schultz, M. G.: Global model simulations of air pollution during the 2003 European heat wave, Atmos. Chem. Phys., 10, 789-815, doi:10.5194/acp-10-789-2010, 2010.

Palmer, P. I., Jacob, D. J., Fiore, A. M., Martin, R. V., and Chance, K.: Mapping isoprene emissions over North America using formaldehyde column observations from space, J. Geophys. Res., 108, 4180, doi:10.1029/2002JD002153, 2003.

Pfister, G. G., Emmons, L., Hess, P. G., Lamarque, J.-F., Orlando, J. J., Walters, S., Guenther, A., Palmer, P. I., and Lawrence, P. J.: Contribution of isoprene to chemical budgets: A model tracer study with the NCAR CTM MOZART-4, J. Geophys. Res., 113, D05308, doi:10.1029/2007JD008948, 2008.

Pison, I. and Menut, L.: Quantification of the impact of aircraft traffic emissions on tropospheric ozone over Paris area, Atmos. En- viron., 38, 971-983, 2004.

Pozzer, A., Jöckel, P., Tost, H., Sander, R., Ganzeveld, L., Kerkweg, A., and Lelieveld, J.: Simulating organic species with the global atmospheric chemistry general circulation model ECHAM5/MESSy1: a comparison of model results with observations, Atmos. Chem. Phys., 7, 2527-2550, doi:10.5194/acp-72527-2007, 2007.

Razavi, A., Karagulian, F., Clarisse, L., Hurtmans, D., Coheur, P. F., Clerbaux, C., Müller, J. F., and Stavrakou, T.: Global distributions of methanol and formic acid retrieved for the first time from the IASI/MetOp thermal infrared sounder, Atmos. chem. Phys., 11, 857-872, doi:10.5194/acp-11-857-2011, 2011.

Roberts, J. M. and Fayer, R. W.: UV absorption cross section of organic nitrates of potential atmospheric importance and estimation of atmospheric lifetimes, Environ. Sci. Technol., 23, 945951, 1989.

Roberts, J. M., Marchewka, M., Bertman, S. B., Goldan, P., Kuster, W., de Gouw, J., Warneke, C., Williams, E., Lerner, B., Murphy, P., Apel, E., and Fehsenfled, F. C.: Analysis of the isoprene chemistry observed during the New England Air Quality Study (NEAQS) 2002 intensive experiment, J. Geophys. Res., 111, D23S12, doi:10.1029/2006JD007570, 2006.

Rudolph, J. and Ehhalt, D. H.: Measurements of C2-C5 hydrocarbons over the North Atlantic, J. Geophys. Res., 86, 1195911964, 1981.

Sander, S. P., Abbatt, J. R., Burkholder, J. B., Friedl, R. R., Golden, D. M., Huie, R. E., Kolb, C. E., Kurylo, G., Moortgat, K., Orkin, V. L. and Wine, P. H.: Chemical kinetics and Photochemical Data for Use in Atmospheric studies, Evaluation No.17, JPL Publication 10-6, Jet Propulsion Laboratory, Pasadena, http: //jpldataeval.jpl.nasa.gov, last access: 26 February 2013, 2011.

Sanderson, M.: Biomass of termites and their emissions of methane and carbon dioxide: a global database. Global Biogeochem. Сy., 10, 543-557, 1996.

Saylor, R. D. and Stein, A. F.: Identifying the causes of differences in ozone production from the CB05 and CBMIV chemical mechanisms, Geosci. Model Dev., 5, 257-268, doi:10.5194/gmd-5257-2012, 2012.

Seiler, W. and Crutzen, P. J.: Estimates of gross and net fluxes of carbon between the biosphere and the atmosphere from biomass burning, Clim. Change, 2, 207-247, 1980.

Schultz, M. G., Backman, L., Balkanski, Y., Bjoerndalsaeter, S., Brand, R., Burrows, J. P., Dalsøeren, S., de Vasconcelos, M., Grodtmann, B., Hauglustaine, D. A., Heil, A., Hoelzemann, J. J., Isaksen, I. S. A., Kaurola, J., Knorr, W., LadstaetterWeissenmayer, A., Mota, B., Oom, D., Pacyna, J., Panasiuk, D., Pereira, J. M. C., Pulles, T., Pyle, J., Rast, S., Richter, A., Savage, N., Schnadt, C., Schultz, M., Spessa, A., Staehelin, J., Sundet, J. K., Szopa, S., Thonicke, K., van het Bolscher, M., van Noije, T. van Velthoven, P. Vik, A. F., Wittrock, F.: REanalysis of the TROpospheric chemical composition over the past 40 years (RETRO) - A long-term global modeling study of tropospheric chemistry, Final Report, Jülich/Hamburg, Germany, 2007 (Published as report no. 48/2007 in the series "Reports on Earth System Science" of the Max Planck Institute for Meteorology, Hamburg, ISSN 1614-1199), 2007.

Shindell, D. T., Faluvegi, F., Stevenson, D. S., Krol, M. C., Emmons, L. K., Lamarque, J.-F., Pétron, G., Dentener, F. J., Ellingsen, K., Schultz, M. G., Wild, O., Amann, M., Atherton, 
C. S., Bergmann, D. J., Bey, I., Butler, T., Cofala, J., Collins, W. J., Derwent, R. G., Doherty, R. M., Drevet, J., Eskes, H. J., Fiore, A. M., Gauss, M., Hauglustaine, D. A., Horowitz, L. W., Isaksen, I. S. A., Lawrence, M. G., Montanaro, V., Müller, J.-F., Pitari, G., Prather, M. J., Pyle, J. A., Rast, S., Rodriguez, J. M., Sanderson, M. G., Savage, N. H., Strahan, S. E., Sudo, K., and Szopa, S: Multimodel ensemble simulations of carbon monoxide: Comparison with observations and projected near-future changes, J. Geophys. Res., 111, D18101, doi:10.1029/2006JD007100, 2006.

Simpson, D.: Biogenic emissions in Europe 2. Implications for ozone control strategies, J. Geophys. Res. Atmos., 100, 2298122906, 1995.

Snider, J. R. and Dawson, G. A.: Tropospheric light alcohols, carbonyls and acetonitrile: Concentrations in the southwestern United States and Henry's law data, J. Geophys. Res. Atmos., 90, 3797-3805, 1985.

Spahni, R., Wania, R., Neef, L., van Weele, M., Pison, I., Bousquet, P., Frankenburg, C., Foster, P. N., Joos, F, Prentice, I. C., and van Velthoven, P.: Constraining global methane emissions and uptake by ecostsyems, Biogeosciences, 8, 1643-1665, doi:10.5194/bg8-1643-2011, 2011.

Stavrakou, T., Müller, J.-F., De Smedt, I., Van Roozendael, M., van der Werf, G. R., Giglio, L., and Guenther, A.: Global emissions of non-methane hydrocarbons deduced from SCIAMACHY formaldehyde columns through 2003-2006, Atmos. Chem. Phys., 9, 3663-3679, doi:10.5194/acp-9-3663-2009, 2009.

Stavrakou, T., Peeters, J., and Müller, J.-F.: Improved global modelling of HOx recycling in isoprene oxidation: evaluation against the GABRIEL and INTEX-A aircraft campaign measurements, Atmos. Chem. Phys., 10, 9863-9878, doi:10.5194/acp-10-98632010, 2010.

Stavrakou, T., Guenther, A., Razavi, A., Clarisse, L., Clerbaux, C., Coheur, P.-F., Hurtmans, D., Karagulian, F., De Maziére, M., Vigouroux, C., Amelynck, C., Schoon, N., Laffineur, Q., Heinesch, B., Aubinet, M., Rinsland, C., and Müller, J.-F.: First space-based derivation of the global atmospheric methanol emission fluxes, Atmos. Chem. Phys., 11, 4873-4898, doi:10.5194/acp-11-4873-2011, 2011.

Stavrakou, T., Müller, J.-F., Peeters, J., Razavi, A., Clarisse, L., Clerbaux, C., Coheur, P. F., Hurtmans, D., De Maziére, M., Vigouroux, C., Deutscher, N. M., Griffith, D. W. T., Jones, N., and Paton-Walsh, C.: Satellite evidence for a large source of formic acid from boreal and tropical forests, Nat. Geosci., 5, 2630, 2012.

Steinkamp, J. and Lawrence, M. G.: Improvement and evaluation of simulated global biogenic soil NO emissions in an AC-GCM, Atmos. Chem. Phys., 11, 6063-6082, doi:10.5194/acp-11-60632011, 2011.

Stevenson, D. S., Dentener, F. J., Schultz, M. G., Ellington, K., van Noije, T. P. C., Wild, O., Zeng, G., Amann, M., Atherton, C. S., Bell, N., Bergmann, D. J., Bey, I., Butler, T., Cofala, J., Collins, W.J., Derwent, R. G., Doherty, R. M., Brevet, J., Eskes, H. J., Fiore, A. M., Gauss, M., Hauglustaine, D. A., Horowitz, L. W., Isaksen, I. S. A., Krol, M. C., Lamarque, J.-F., Lawrence, M. G., Montanaro, V., Müller, J.-F., Pitari, G., Prather, M. J., Pyle, J. A., Rast, S., Rodriguez, J. M., Sanderson, M. G., Savage, N. H., Shindell, D. T., Strahan, S. E., Sudo, K., and Szopa, S.: Multimodel ensemble simulations of present-day and near-future tropospheric ozone, J. Geophys. Res., 111, D08301,
doi:10.1029/2005JD006338, 2006.

Tao, Z., Larson, S. M., Wuebbles, D. J., Williams, A., and Caughey, M.: A summer simulation of biogenic contributions to groundlevel ozone over the continental United States, J. Geophys. Res., 108, 4404, doi:10.1029/2002JD002945, 2003.

Thouret, V., Marenco, A., Logan, J. A., Nédélec, P., and Grouhel, C.: Comparisons of ozone measurements from the MOZAIC airborne program and the ozone sounding network at eight locations, J. Geophys. Res., 103, 25695-25720, 1998.

Tie, X., Guenther, A., and Holland, E.: Biogenic methanol and its impacts on tropospheric oxidants, Geophys. Res. Letts., 30, 1881-1884, doi:10.1029/2003GL017167, 2003.

van Weele, M., Williams, J. E., van Velthoven, P. F. J., Brenninkmeijer, C. A. M., and Schuck, T. J.: Three-dimensional reanalysis of the balance between methane sources and sinks from 2000 to 2009, in preparation, 2013.

van der A, R. J., Allaart, M. A. F., and Eskes, H. J.: Multi sensor reanalysis of total ozone, Atmos. Chem. Phys., 10, 11277-11294, doi:10.5194/acp-10-11277-2010, 2010.

van der Werf, G. R., Randerson, J. T., Giglio, L., Collatz, G. J., Mu, M., Kasibhalta, P. S., Morton, D. C., DeFries, R. S., Jin, Y., and van Leeuwen, T. T.: Global fire emissions and the contribution of deforestation, savanna, forest, agricultural and peat fires (19972009), Atmos. Chem. Phys., 10, 11707-11735, doi:10.5194/acp10-11707-2010, 2010.

von Kuhlmann, R., Lawrence, M. G., Pöschl, U., and Crutzen, P. J.: Sensitivities in global scale modeling of isoprene, Atmos. Chem. Phys., 4, 1-17, doi:10.5194/acp-4-1-2004, 2004.

Wang, K.-Y. and Shallcross, D. E.: Modelling terrestrial biogenic isoprene fluxes and their potential impact on global chemical species using a coupled LSM-CTM model, Atmos. Environ., 34, 2909-2925, 2000.

Wiedinmyer, C., Tie, X., Guenther, A., Neilson, R., and Granier, C.: Future changes in biogenic isoprene emissions: How might they affect regional and global atmospheric chemistry?, Earth. Interact., 10, 18 pp., 2006.

Williams, J. E. and van Velthoven, P. F. J.: Uncertainty in the Future Distribution of Tropospheric Ozone over West Africa due to Variability in Anthropogenic Emissions Estimates between 2025 and 2050, Int. J. Geophys., 10, 324359, doi:10.1155/2011/324359, 2011.

Williams, J. E., Scheele, M. P., van Velthoven, P. F. J., Cammas, J.-P., Thouret, V., Galy-Lacaux, C., and Volz-Thomas, A.: The influence of biogenic emissions from Africa on tropical tropospheric ozone during 2006: a global modeling study, Atmos. Chem. Phys., 9, 5729-5749, doi:10.5194/acp-9-5729-2009, 2009.

Williams, J. E., Strunk, A., Huijnen, V., and van Weele, M.: The application of the Modified Band Approach for the calculation of on-line photodissociation rate constants in TM5: implications for oxidative capacity, Geosci. Model Dev., 5, 15-35, doi:10.5194/gmd-5-15-2012, 2012a.

Williams, J. E., van Weele, M., van Velthoven, P. F. J., Scheele, M. P., Liousse, C., and van der Werf, G. R.: The Impact of Uncertainties in African Biomass Burning emission estimates on modeling global air quality, long range transport and tropospheric chemical lifetimes, Atmosphere, 3, 132-163, doi:10.3390/atmos2010132, 2012 b. 
Yarwood, G., Rao, S., Yocke, M., and Whitten, G.: Updates to the carbon bond chemical mechanism: CB05. Final report to the US EPA, EPA Report Number: RT-0400675, available at: www.camx.com, last access: 25 October 2012, 2005.

Yienger, J. J. and Levy, H.: Empirical model of global soil-biogenic $\mathrm{NO}_{\mathrm{x}}$ emissions, J. Geophys. Res., 100, 11447-11464, 1995.

Yonemura, S., Kawashima, S., and Tsuruta, H.: Carbon monoxide, hydrogen and methane uptake by soils in a temperate arable field and a forest, J. Geophys. Res.-Atmos., 105, 14347-14362, 2000.

Zahn, A., Brenninkmeijer, C. A. M., Asman, W. A. H., Crutzen, P. J., Heinrich, G., Fischer, H., Cuijpers, J. W. M., and van Velthoven, P. F. J.: Budgets of $\mathrm{O}_{3}$ and $\mathrm{CO}$ in the upper troposphere: CARIBIC passenger aircraft results 1997-2001, J. Geophys. Res., 107, 4337, doi:10.1029/2001JD001529, 2002.
Zare, A., Christensen, J. H., Irannejad, P., and Brandt, J.: Evaluation of two isoprene emission models for use in a longrange air pollution model, Atmos. Chem. Phys., 12, 7399-7412, doi:10.5194/acp-12-7399-2012, 2012.

Zaveri, R. A. and Peters, L. K.: A new lumped structure photochemical mechanism for large-scale applications, J. Geophys. Res., 104, 30387-30415, doi:10.1029/1999JD900876, 1999.

Zhou, X. and Mopper, K.: Apparent partition coefficients of 15 carbonyl compounds between air and seawater and between air and freshwater: Implications for air-sea exchange, Environ. Sci. Tech., 24, 1864-1869, 1990. 